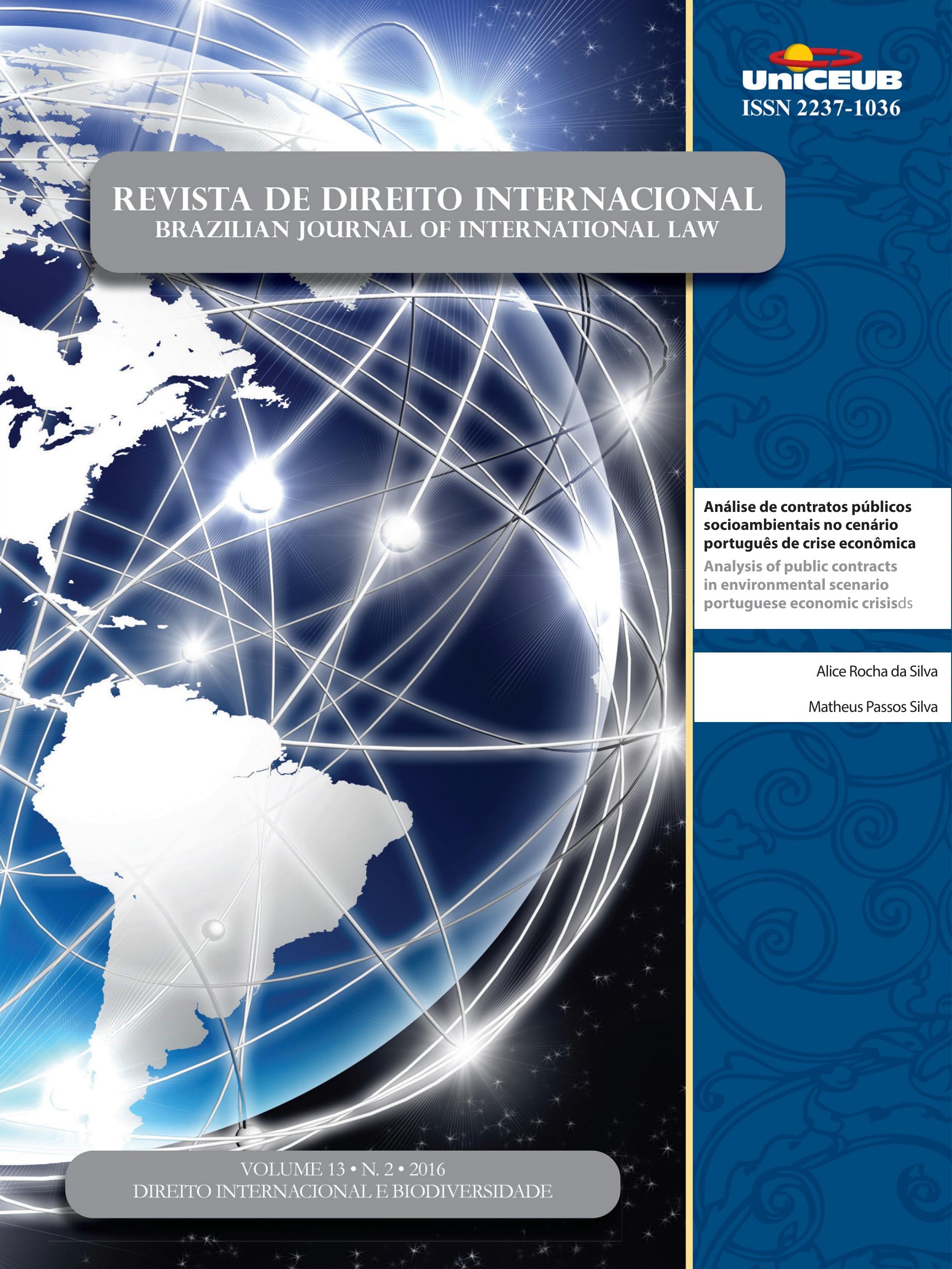




\section{Sumário}

CRÔNICAS DE DIREITO INTERNACIONAL PRIVADO 3 Gustavo Ferreira Ribeiro, Inez Lopes Matos Carneiro de Farias, Nadia de Araujo e Marcelo De Nardi

EDITORIAL 22

Márcia Dieguez Leuzinger e Solange Teles da Silva

IMPROVING THE EFFECTIVENESS OF LEGAL ARRANGEMENTS TO PROTECT BIODIVERSITY: AUSTRALIA AND BRAZIL .25

Paul Martin, Márcia Dieguez Leuzinger e Solange Teles da Silva

O RECONHECIMENTO DA DIGNIDADE DOS ELEMENTOS DA BIODIVERSIDADE COM BASE NO DIÁLOGO ENTRE O DIREITO INTERNACIONAL E O ORDENAMENTO JURÍDICO BRASILEIRO

Augusto César Leite de Resende

O REGIME INTERNACIONAL DO CLIMA E A PROTEÇÃO AOS “REFUgIADOS CLIMÁTICOS”: QUAIS DESAFIOS DA COP 21?

Ana Carolina Barbosa Pereira Matos e Tarin Cristino Frota Mont'Alverne

A anÁlise do MECANismo REdD+ COM Vistas À MitigaÇÃo dos EFEITOS DAS MUdANÇAS CLIMÁTICAS E À PROTEÇÃO DA DIVERSIDADE BIOLÓGICA FLORESTAL

Diogo Andreola Serraglio e Heline Sivini Ferreira

ECOLABELS DE EFICIÊNCIA ENERGÉtiCA E SUA CONSISTÊNCIA COM A DISCIPLINA DOS PPM's E PROVISÕES dOs Acordos GATT E TBT.

Cristiane Derani e Arthur Rodrigues Dalmarco

ANÁLISIS DEL ORDENAMIENTO JURÍDICO INTERNACIONAL SOBRE PROTECCIÓN DE LOS RECURSOS GENÉTICOS: DESAFIOS Y PERSPECTIVAS EN URUGUAY A PARTIR DE LA IMPLEMENTACIÓN DEL PROTOCOLO DE NAgOYA 115

Alina Celi 
LE RÉGIME INTERNATIONAL DE L'ACCÈS AUX RESSOURCES GÉNÉTIQUES AU PRISME DE L'ENTRÉE

en VIgUeUr du Protocole de NAgoya .............................................................. 131

Rodolpho Zahluth Bastos, Otávio Canto, Karine Galy e Isabelle Vestris

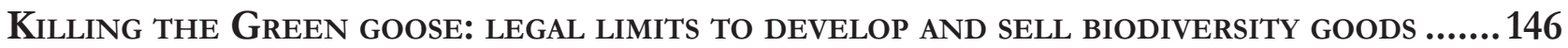
José Augusto Fontoura Costa e Liziane Paixão Silva Oliveira

VÍNCULO SUBSTANCIAL E AS BANDEIRAS DE CONVENIÊNCIA: CONSEQUÊNCIAS AMBIENTAIS DECORRENTES DOS NAVIOS COM REGISTROS ABERTOS ....................................................... 160

Marcos Edmar Ramos Alvares da Silva e André de Paiva Toledo

ANÁLISE DE CONTRATOS PÚblicos SOCIOAMBIENTAIS NO CENÁRIO PORTUGUÊS DE CRISE ECONÔ-

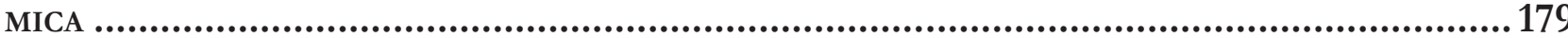

Alice Rocha da Silva e Matheus Passos Silva

A ORganizaÇão do TRATAdo DE COOPERAÇão AMAZÔNICA: UMA ANÁLISE CRÍTICA dAS RAZÕES POR TRÁS DA SUA CRIAÇÃO E EVOLUÇÃO

Paulo Henrique Faria Nunes

O uso de EXPERTS EM Controvérsias ambientais Perante a CorTe InTERnacional de JusTIÇA ........................................................................................................245

Lucas Carlos Lima

Os VIESES dA BIODIVERSIDAdE APRESENTAdos PELO CASO do PARQUE EÓlico DE BALd HiLls ......261 Natália Zampieri e Mariana Cabral

Mining CBD 275

Claire Lajaunie e Pierre Mazzega

Biotecnologia moderna, direito e o pensamento Abissal

Reichardt, F.V., Garavello, M. E. P. E., Molina, S.M.G. e Ballester, M. V. R.

Community Core Values como parâmetro de efetivação dos Princípios da Precaução e da Participação Popular em instrumentos de controle de projeto atividade de alta COMPLEXIDADE AMBIENTAL................................................................................... 314

Michelle Lucas Cardoso Balbino 
Discussões BIOTECNOLÓgICAS QUANTO AOS ORGANISMOS GENETICAMENTE MODIFICADOS NO ÂMBito da OMC: do contencioso ao acordo de vontades entre Argentina e União EuroPEIA

Gustavo Paschoal Oliveira

O Trans-Pacific Partnership Agreement e seus potenciais impactos para a regulação

DA BIODIVERSIDADE NO ÂMBITO TRANSNACIONAL..........................................................375

Mariana Yante Barrêto Pereira

AS ÁREAS PROTEGIDAS TRANSFRONTEIRIÇAS: REFLEXÕES CRÍTICAS ACERCA DE UM USO GEOPOLÍTICO DO DIREITO DA BIODIVERSIDADE.

Rabah Belaidi

O Que o caso Estados Unidos vs. Texas nos dirá sobre o direito de IMigração nos EsTADOS UNIDOS? 409

Danielle Anne Pamplona

Clóvis Beviláqua e a justiça internacional: entre o sim E o Não a Rui Barbosa.... .422 Paulo Emílio Vauthier Borges de Macedo

Possibilidade de delegação de atribuição para a Celebração de Tratados pela RepúbliCa Federativa do Brasil: análise do artigo 84, VIII c/c Parágrafo único da ConstituiÇão FEDERAL

Luciano Monti Favaro e Héctor Valverde Santana

Dignity, ubuntu, HUMANiTY AND AUTONOMOUS WEAPON SYSTEMS (AWS) DEBATE: AN AfRiCAN PERSPECTIVE 460

Thompson Chengeta

DiREITO INTERNACIONAL PRIVADO E O DIREITO TRANSNACIONAL: ENTRE A UNIFICAÇÃO E A ANARQUIA .503

André De Carvalho Ramos

A ilusória ausênCia do termo DépeÇage na JURisprudênCia brasileira de contratos INTERNACIONAIS

Gustavo Ferreira Ribeiro 
O EFEITO DIRETO DAS DIRETIVAS E OS DIREITOS FUNDAMENTAIS........................................535 Lucas Fonseca e Melo e José Levi Mello do Amaral Júnior

DA APLICABILIDADE DO BULK FACTORING AOS GRUPOS DE SOCIEDADES 565 Daniel Amin Ferraz e Leonardo Arêba Pinto

A Questão hermenêutica no direito das GENTES ................................................580 Inocêncio Mártires Coelho 


\title{
Análise de contratos públicos socioambientais no cenário português de crise econômica*
}

\section{Analysis of public contracts in environmental scenario portuguese economic crisis}

\author{
Alice Rocha da Silva** \\ Matheus Passos Silva***
}

\section{Resumo}

O presente artigo pretende verificar, na adjudicação dos contratos públicos celebrados entre os anos de 2010 e 2014, se o administrador público português priorizou fatores econômicos - o que estaria em acordo com o momento de crise econômica atual em que a redução dos gastos públicos se apresenta como elemento fundamental para a administração pública - ou se priorizou fatores socioambientais - o que estaria em acordo com as diretivas de 2004 e de 2014 acerca da contratação pública, nas quais o papel do Estado aparece como fundamental na proteção ao meio ambiente e na promoção da retomada do crescimento econômico. Para atingir tal objetivo, estruturou-se o texto em três partes principais. A primeira traz a inserção dos critérios socioambientais nas diretivas de 2004 e sua transposição para o ordenamento jurídico português, além de breve análise acerca das inovações trazidas pelas diretivas de 2014. Na segunda parte, faz-se a apresentação da estratégia Europa 2020 e do Memorando de Entendimento sobre as Condicionalidades da Política Econômica de Portugal, documentos que em princípio podem se apresentar como contraditórios por defenderem, respectivamente, o maior e o menor papel do Estado na economia. Ainda na segunda parte apresentam-se pontos positivos e negativos acerca da contratação pública sustentável. Por fim, na terceira parte são analisados relatórios dos contratos públicos celebrados por Portugal em 2010 e em 2013 e, ainda, analisam-se 162 anúncios de contratos públicos divulgados no período, com o objetivo de verificar o peso dos critérios socioambientais em tais contratos. A conclusão à qual se chegou é que os critérios econômicos vinculados à redução do gasto público foram preponderantes na adjudicação dos contratos públicos celebrados no período analisado, com os critérios socioambientais tendo sido relegados a segundo plano - isto quando estiveram presentes.

Palavras-chave: Contratação pública sustentável. Crise econômica. Gasto público. Diretivas europeias de contratação. Contratos públicos.

\section{Abstract}

This article aims to verify, the award of public contracts between the years 2010 and 2014, if the portuguese public administrator prioritized economic 
factors - which would be in accordance with the time of the current economic crisis in which the reduction of public expenditure presents as a fundamental element for public administration - or prioritized environmental factors - which would be in accordance with the 2004 directives and 2014 on the procurement, in which the state's role appears as fundamental in protecting the environment and promoting resumption of economic growth. To achieve this goal, the text was structured into three main parts. The first brings the inclusion of social and environmental criteria in the 2004 guidelines and their transposition into the Portuguese legal system, as well as brief analysis about the innovations introduced by the 2014 guidelines the second part, it is the presentation of the Europe 2020 strategy and the Memorandum of Understanding on the economic Policy conditionality of Portugal, documents can in principle be presented as contradictory to defend, respectively, the largest and the smallest role in the economy. Still in the second part they present positive and negative points about sustainable procurement. Finally, in the third part are analyzed procurement reports signed by Portugal in 2010 and in 2013 and also are analyzed 162 public procurement notices published in the period, in order to verify the weight of social and environmental criteria in such contracts. The conclusion that was made is that economic criteria linked to the reduction of public spending were preponderant in the award of public contracts in the period analyzed, with social and environmental criteria have been relegated to the background - that when they were present.

Keywords: Sustainable public contracts. Economic crisis. Public spending. European procurement directives. Public contracts.

\section{INTRODUÇÃo}

A preocupação com a proteção do meio ambiente tornou-se um dos principais aspectos a serem considerados pela sociedade e pelo Estado em seu momento atual. Nesse sentido, a partir das décadas de 1960-70, surgiram, concomitantemente, movimentos sociais representados por Organizações Não-governamentais (ONGs) tais como a Greenpeace e a WWF - e movimentos estatais - tais como a Conferência de Estocolmo, de 1972 - cujo objetivo central é a defesa de um meio ambiente ecologicamente equilibrado.
Ainda no âmbito da atuação estatal, destaca-se que o movimento em defesa do meio ambiente também se refletiu no Pacto Internacional sobre os Direitos Econômicos, Sociais e Culturais e, ainda, nas novas constituições surgidas a partir de tal período, tais como na Constituição portuguesa de 1976, na espanhola de 1978 e na brasileira de 1988. Em outras Constituições, tais como na italiana, na francesa e na russa, a defesa do meio ambiente, também, está explícita, o que demonstra a importância que o tema possui nos dias atuais.

Ainda que a preservação do ambiente seja um direito-dever de todos os cidadãos, já que a eventual degradação total dos recursos naturais implicaria, em última instância, na própria extinção da espécie humana, parece inegável que o Estado, também, possui papel fundamental nesse processo, especialmente em relação ao contexto de poder atuar, senão como o principal, ao menos como um dos principais indutores de processos que levem à proteção do meio ambiente e de sua garantia para as gerações atuais e futuras.

Em outras palavras, o que se afirma é que o Estado, entendido como uma instituição que tem peso importante no que concerne aos processos econômicos da sociedade, se apresenta como promotor da defesa do meio ambiente por meio de suas compras públicas, já que, ao estabelecer critérios socioambientais em seus concursos para a adjudicação de contratos públicos, essa instituição pode exigir que sejam utilizados os chamados critérios verdes que levem à promoção do bem comum que é o meio ambiente.

Por outro lado, o mundo atual passa por inegável crise econômica, a qual já perdura por alguns anos. Tendo tal processo se iniciado em 2008 nos Estados Unidos, a crise parece ter atingido seu auge em 2010, quando inúmeros Estados vieram a necessitar de auxílio econômico de entidades internacionais, com destaque, no caso europeu, para a Grécia, Chipre, Irlanda e também Portugal, países que foram auxiliados pela chamada Troika - composta pelo Fundo Monetário Internacional (FMI), pelo Banco Central Europeu (BCE) e pela Comissão Europeia (CE).

Em contexto de crise econômica, uma das principais exigências feitas pela Troika para confirmar o auxílio financeiro aos Estados afetados estava relacionada à redução do gasto público, visto como o principal vilão a ser combatido. Nesse sentido cabia a tais Estados o estabelecimento de um programa de ajustamento eco- 
nômico fundado na austeridade fiscal de maneira a se reduzir os gastos estatais, por um lado, e, também, o próprio custo da instituição Estado, por outro, com vistas ao reequilíbrio das contas públicas, de maneira a fazer com que tais sociedades pudessem retomar o caminho do crescimento.

A situação descrita gera um aparente conflito: por um lado, o Estado precisa realizar ações institucionais em defesa do meio ambiente, o que pode ser entendido como gasto público; por outro, precisa conter esses mesmos gastos públicos de maneira a receber o apoio de instituições internacionais que possam lhe garantir a liquidez necessária para sua própria manutenção. Surge então o problema a ser debatido neste texto: o estabelecimento de contratos públicos com viés de sustentabilidade ambiental - e que pressupõem um maior gasto público - entra em contradição com um contexto de restrição econômica devido à necessidade de redução dos gastos públicos?

Objetivando-se responder a tal questionamento, o texto a seguir está dividido em três partes principais. $\mathrm{Na}$ primeira delas, faz-se a apresentação das diretivas europeias acerca do tema "contratação pública". Nesse sentido são mostradas as principais características das diretivas de 2004, com ênfase às possibilidades de contratação pública socioambiental. Em seguida apresenta-se o processo de criação do Código dos Contratos Públicos de Portugal - o Decreto-Lei no 18/2008, de 29 de Janeiro - como mecanismo de transposição para o ordenamento jurídico interno deste Estado daquilo que estava previsto nas diretivas de 2004. Por fim fala-se a respeito do processo de atualização das diretivas de 2004, o qual resultou nas diretivas de 2014, e do papel fundamental a ser desempenhado por essas novas diretivas no sentido de se adequar a proteção ao meio ambiente e as conquistas sociais do Estado de bem-estar social à atual crise econômica.

$\mathrm{Na}$ segunda parte, são feitos apontamentos doutrinários acerca da contratação pública sustentável em tempos de crise econômica. Nesse contexto apresenta-se a proposta feita pela Comissão Europeia intitulada estratégia Europa 2020, na qual defende-se, vigorosamente, a contratação pública como um mecanismo que possa, ao mesmo tempo, proteger o meio ambiente e incentivar a manutenção do nível de vida da população europeia como um todo. Em seguida são destacados os principais pontos acerca do Memorando de
Entendimento sobre as Condicionalidades da Política Econômica de Portugal, documento assinado por esse Estado juntamente a organismos internacionais com o objetivo de se receber auxílio econômico em troca, eminentemente, da redução dos gastos públicos. Por fim são trazidas algumas ideias acerca dos problemas e dos benefícios decorrentes da inclusão de critérios socioambientais na contratação pública em geral.

$\mathrm{Na}$ última parte do texto, analisa-se a situação dos contratos públicos de Portugal com o objetivo de verificar qual foi a opção escolhida pelo administrador público português - se o incentivo à redução do gasto público ou o incentivo a contratos públicos sustentáveis. Para tanto foram analisados relatórios referentes aos contratos públicos feitos pela administração pública portuguesa em 2010 e em 2013 e, por fim, foi feito um estudo de caso com 162 anúncios de contratos públicos do Estado português com o objetivo de se verificar o peso dos critérios socioambientais nestes contratos.

\section{AS DIRETIVAS EUROPEIAS SOBRE A CONTRATAÇÃO PÚBLICA E SUA TRANSPOSIÇÃO PARA O DIREITO PORTUGUÊS}

A contratação pública pode ser entendida como um dos principais mecanismos de atuação do Estado no âmbito público, especialmente no que concerne ao estímulo econômico. Nesse sentido é importante destacar que Portugal, que se tornou membro da então Comunidade Econômica Europeia em 1985, precisa seguir aquilo que é definido pela União. Nesse contexto ganham destaque as diretivas europeias sobre contratação pública, nomeadamente as Diretivas de 2004 e as Diretivas de 2014.

De maneira genérica, entendem-se por diretivas os atos legislativos que fixam objetivos gerais a todos os Estados-membros da União Europeia, objetivos estes que tais países devem alcançar. Fica, contudo, a critério de cada país estabelecer a maneira pela qual tais objetivos serão alcançados ${ }^{1}$, ainda que os países precisem integrar o conteúdo das diretivas à sua legislação interna - o que significa, por outras palavras, que é obrigatório

1 UNIÃO EUROPEIA. Direito da UE. Regulamentos, directivas e outros actos legislativos, 2015. Disponível em: <http://europa.eu/eulaw/decision-making/legal-acts/index_pt.htm>. Acesso em: 20 jul. 2015. 
aos países submetidos às diretivas sua transposição para o ordenamento jurídico interno de maneira a fazer cumprir a diretiva transposta ${ }^{2}$.

É possível reconhecer a existência de dois grupos principais de diretivas no que concerne aos contratos públicos. Por um lado, existem as diretivas de 2004, nomeadamente as diretivas 2004/17/CE e 2004/18/ CE; por outro, destacam-se as diretivas de 2014 quais sejam, as diretivas 2014/23/UE, 2014/24/UE e 2014/25/UE -, que são resultantes do processo de revisão das diretivas de 2004.

\subsection{As diretivas de 2004 e o surgimento dos critérios socioambientais nos contratos públicos}

O processo que deu origem às diretivas de 2004 sobre contratos públicos se iniciou em 1996, com a comunicação intitulada "Livro Verde sobre os mercados públicos”. Fez-se, em tal ocasião, inúmeras críticas aos Estados-membros, especialmente pelo fato de haver transposição deficiente das diretivas ao ordenamento jurídico interno dos Estados-membros, por um lado isto quando ocorria a transposição -, e, por outro, críticas em relação aos procedimentos adotados durante a transposição, os quais muitas vezes iam em direção contrária aos que estava previsto nas próprias diretivas ${ }^{3}$.

No ano 2000, foram apresentadas novas propostas para a reestruturação das diretivas então existentes, tanto da diretiva referente aos chamados setores tradicionais quanto à atinente aos chamados setores especiais ${ }^{4}$. O re-

2 "Os Estados têm o dever de proceder à transposição das diretivas para o Direito interno. A escolha do tipo de ato destinado a implementar a diretiva releva do sistema jurídico de cada Estadomembro". Desta maneira entende-se que as Diretivas dirigem-se aos Estados-membros e não aos indivíduos diretamente. Contudo, para evitar que os cidadãos de determinado Estado-membro que ainda não tiver realizado a transposição das diretivas para seu próprio ordenamento tenha tratamento desigual comparativamente àquele cidadão de Estado-membro que já transpôs as diretivas tem-se que “o TJ [Tribunal de Justiça da União Europeia] considerou que, verificados certos requisitos, as normas das diretivas podem produzir efeitos em relação aos indivíduos, mesmo antes da sua transposição. $\mathrm{O}$ efeito direto resulta, portanto, da necessidade de proteger os cidadãos contra a inércia do Estado". A este respeito ver MARTINS, Ana Maria Guerra. Manual de direito da União Europeia. Coimbra: Almedina, 2014. p. 476-477; p. 522-528.

3 ESTORNINHO, Maria João. Curso de direito dos contratos públicos: por uma contratação pública sustentável. Coimbra: Almedina, 2014. p. 91.

4 Por setores tradicionais entendem-se os contratos que se referem à "adjudicação de fornecimentos públicos, de prestação de serviços públicos e de empreitada de obras públicas", enquanto os setores espe- sultado foi a aprovação, em março de 2004, da diretiva 2004/17/CE, "relativa à coordenação dos processos de adjudicação de contratos nos sectores da água, da energia, dos transportes e dos serviços postais" ", e da diretiva 2004/18/CE, "relativa à coordenação dos processos de adjudicação dos contratos de empreitada de obras públicas, dos contratos públicos de fornecimento e dos contratos públicos de serviços" ". Ambas as Diretivas pressupunham sua entrada imediata em vigor, a partir de $1^{\circ}$ de maio de 2004, com prazo de transposição pelos Estados-membros até 31 de janeiro de 2006, à exceção dos serviços postais, com prazo até $1^{\circ}$ de janeiro de $2009^{7}$.

De maneira geral, as diretivas de 2004 não podem ser entendidas como mera "compilação" dos textos das diretivas anteriores que tratavam desses tipos de contratação pública. Nesse contexto é importante destacar que essas diretivas trouxeram embutidas em si uma nova perspectiva para os Estados-membros realizarem as contratações públicas, qual seja, a de perseguirem políticas públicas de cunho social e ambiental ${ }^{8}$. Em outras palavras, tem-se que a contratação pública deixou de ser vista como mero mecanismo de compra por parte do Estado e passou a se configurar como verdadeiro mecanismo de incentivo de políticas públicas a serem desenvolvidas pelo Estado, com ênfase aos aspectos ambientais da contratação?.

ciais estão vinculados aos "processos de adjudicação nos setores da água, da energia e dos transportes”. ESTORNINHO, Maria João. Curso de direito dos contratos públicos: por uma contratação pública sustentável. Coimbra: Almedina, 2014. p. 93.

5 UNIÃO EUROPEIA. Directiva 2004/17/CE do Parlamento Europeu e do Conselho, de 31 de Março de 2004. Relativa à coordenação dos processos de adjudicação de contratos nos sectores da água, da energia, dos transportes e dos serviços postais. Jornal Oficial, n. L 134, de 30 de abril de 2004, p. 1-113. Disponível em: < http: / / eur-lex. europa.eu/legal-content/PT/TXT/?uri=CELEX:32004L0017>. Acesso em: 20 jul. 2015. p. 1-113.

6 UNIÃO EUROPEIA. Directiva 2004/18/CE do Parlamento Europeu e do Conselho, de 31 de Março de 2004. Relativa à coordenação dos processos de adjudicação dos contratos de empreitada de obras públicas, dos contratos públicos de fornecimento e dos contratos públicos de serviços. Jornal Oficial, n. L 134, de 30 de abril de 2004, p. 114-240. Disponível em: < http://eur-lex.europa.eu/legalcontent/PT/TXT/?uri=CELEX:32004L0018>. Acesso em: 20 jul. 2015. p. 114-240.

7 ESTORNINHO, Maria João. Curso de direito dos contratos públicos: por uma contratação pública sustentável. Coimbra: Almedina, 2014. p. 95 , nota 111.

8 ESTORNINHO, Maria João. Curso de direito dos contratos públicos: por uma contratação pública sustentável. Coimbra: Almedina, 2014. p. 98.

9 "A contratação pública serve (sempre) à prossecução de políti- 
Nesse sentido as diretivas de 2004 trouxeram duas inovações quando em comparação com as diretivas anteriores sobre o tema. A primeira delas se refere aos critérios de adjudicação, já que estabeleceram, claramente, que os contratos podem ser escolhidos tendo-se em vista o critério do preço mais baixo ${ }^{10}$ ou o da proposta economicamente mais vantajosa ${ }^{11}$ - desde que resguardados, é claro, os princípios basilares presentes no Tratado de Funcionamento da União Europeia (TFUE), nomeadamente os princípios da transparência, da não discriminação e da igualdade ${ }^{12}$, que têm por objetivo a garantia da concorrência efetiva.

A segunda inovação diz respeito ao fato de que as diretivas de 2004 estabeleceram a possibilidade dos Estados-membros incluírem critérios sociais e ambientais em seus respectivos procedimentos de adjudicação. Em consonância com a ideia de proposta economicamente mais vantajosa e, ainda, de acordo com a perspectiva de que a contratação pública pode ser utilizada como verdadeira política pública, as diretivas trazem, já em seus considerandos, a ideia de que compete aos Estados-membros estabelecerem, como critério de adjudicação, a satisfa-

cas públicas concretas, de objectivos concretos, e pode por isso ser equacionada enquanto mais um instrumento - ao lado das demais medidas administrativas - ao dispor dos governos". RAIMUNDO, Miguel Assis. A formação dos contratos públicos: uma concorrência ajustada ao interesse público. Lisboa: AAFDL, 2013. p. 395.

10 É importante chamar a atenção para o fato de que as propostas que têm como critério de adjudicação o prȩ̣o mais baixo permitem a inclusão de critérios socioambientais, seja na fase da pré-qualificação ou "como requisitos obrigatórios a serem observados durante a execução do contrato". ALENCASTRO, Maria Alice Cruz; SILVA, Edson Vicente da; LOPES, Ana Maria D'Ávila. Contratações sustentáveis na administração pública brasileira: a experiência do Poder Executivo federal. Revista de Administração Pública, Rio de Janeiro, v. 48, n. 1, jan./fev. 2014. p. 215. No entanto, o enfoque deste texto será nos critérios explícitos de adjudicação constantes nos anúncios dos contratos, conforme será exposto na Parte 3 infra.

11 Destaca-se que a proposta economicamente mais vantajosa não será, necessariamente, a mais barata, já que a entidade adjudicante poderá colocar, em seu caderno de encargos, pesos específicos (valoração diferente) para outros critérios que não apenas o preço. Em outras palavras, se o preço for o único critério da adjudicação, então necessariamente o Estado deve escolher a proposta mais barata; contudo, se o preço mais baixo corresponder a $40 \%$ dos critérios e se aspectos técnicos corresponderem aos demais $60 \%$, então, não necessariamente, a proposta mais barata será a vencedora. O critério da proposta economicamente mais vantajosa é fundamental para a compreensão da análise que será feita mais à frente neste texto, especialmente quando se considera a possibilidade de inclusão de critérios socioambientais que transformem a proposta mais barata em proposta economicamente mais vantajosa.

12 ESTORNINHO, Maria João. Curso de direito dos contratos públicos: por uma contratação pública sustentável. Coimbra: Almedina, 2014. p. 105-106. ção de objetivos sociais e ambientais para além dos objetivos, apenas, econômicos ${ }^{13}$. Logo, permite-se que os Estados-membros estipulem, por exemplo, que só celebrarão contratos públicos com empresas que garantam a proteção do meio ambiente ou que se comprometam a criar um número " $\mathrm{x}$ " de empregos em determinada região do país.

Em síntese, tem-se que as diretivas de 2004 vieram a permitir que a entidade adjudicante leve em consideração as consequências ambientais das propostas bem como os custos de utilização dos bens ou serviços. Assim, com base nessas diretivas, compete à entidade adjudicante buscar a melhor relação qualidade/preço dentre as propostas, ao mesmo tempo em que as diretivas permitem também que as entidades adjudicantes considerem aquelas propostas que mais "poderão contribuir para a proteção do ambiente e para a promoção do desenvolvimento sustentável"14.

\subsection{A transposição das diretivas europeias de 2004 para o direito português}

A partir do momento em que o Direito Comunitário aprofundou suas definições de contrato público, Portugal não poderia deixar de rever, tanto do ponto de vista doutrinário quanto legal, sua própria definição de contrato público. Assim, se em um primeiro momento a definição portuguesa de contrato público estava diretamente relacionada à noção de contrato administrativo, excluídos

13 Tais critérios socioambientais podem estar presentes nos contratos celebrados pelos Estados-membros "desde que aqueles critérios estejam ligados ao objeto do contrato, não confiram à entidade adjudicante liberdade de escolha ilimitada, sejam expressamente indicados e respeitem os princípios fundamentais". ESTORNINHO, Maria João. Curso de direito dos contratos públicos: por uma contratação pública sustentável. Coimbra: Almedina, 2014. p. 105.

14 Ressalte-se que os critérios de promoção socioambientais podem ser exigidos pelas entidades adjudicantes desde que os mesmos: a) constem nos documentos do concursos; b) sejam objetivos; e c) sejam não discriminatórios. Ainda, as entidades adjudicantes devem indicar a ponderação relativa atribuída a cada critério a tempo de os proponentes elaborarem as suas propostas, ou seja, podem exigir um método específico para a concretização de seus objetivos socioambientais ou podem exigir efeitos socioambientais específicos decorrentes da concretização das propostas desde que as mesmas sejam previamente explicitadas. Assim, espera-se que os concorrentes saibam, de antemão, quais são as especificações técnicas de promoção socioambiental, garantindo-se assim os princípios gerais da transparência, da não discriminação e da igualdade. A este respeito ver ESTORNINHO, Maria João. Curso de direito dos contratos públicos: por uma contratação pública sustentável. Coimbra: Almedina, 2014. p. 297-298. 
dessa definição os contratos de direito privado da Administração Pública, a partir do início dos anos 2000, a doutrina foi, gradualmente, aproximando as duas definições, já que não parece mais ser possível separar o procedimento pré-contratual do próprio regime substantivo do contrato público ${ }^{15}$.

Desta feita, identificam-se por contratos públicos aqueles em que a Administração Pública aparece como outorgante, mesmo no caso de contratos celebrados, exclusivamente, entre entidades privadas mas com fins de interesse público ${ }^{16}$. De maneira mais específica, pode-se definir um contrato público pelo seu critério de interesse, qual seja, a concretização de fins de interesse públi$\mathrm{CO}^{17}$. Além disto, destaca-se que um contrato público se caracteriza, também, pela origem do seu financiamento, ou seja, pelos meios financeiros envolvidos: utiliza-se dinheiro público para sua concretização ${ }^{18}$. Fica claro, dessa forma, que, mesmo os contratos que busquem interesses públicos e também privados, podem ser classificados como contratos públicos, desde que de alguma forma se relacionam a interesses públicos e se utilizem de recursos públicos ${ }^{19}$.

Uma vez clara a definição de contrato público, torna-se necessário averiguar de que maneira ocorreu a transposição das diretivas europeias para o direito português. Nesse sentido o grande avanço na legislação portuguesa no âmbito dos contratos públicos se deu com a elaboração do chamado Código dos Contratos Públicos (CCP), de 2008, o qual objetivou a transposição, para o direito português, das diretivas setores clássicos e setores especiais de 2004. O CCP foi visto como verdadeiro marco na legis-

15 ESTORNINHO, Maria João. Curso de direito dos contratos públicos: por uma contratação pública sustentável. Coimbra: Almedina, 2014. p. 319.

16 Nesse sentido é importante destacar que a existência do contrato pressupõe a declaração explícita de vontade de ambas as partes, o que diferenciaria o contrato do ato administrativo. A esse respeito ver ESTORNINHO, Maria João. Curso de direito dos contratos públicos: por uma contratação pública sustentável. Coimbra: Almedina, 2014. p. 320-321.

17 ESTORNINHO, Maria João. Curso de direito dos contratos públicos: por uma contratação pública sustentável. Coimbra: Almedina, 2014. p. 328.

18 ESTORNINHO, Maria João. Curso de direito dos contratos públicos: por uma contratação pública sustentável. Coimbra: Almedina, 2014. p. 329.

19 Uma síntese da definição de contrato público como um mecanismo de concretização do interesse público pode ser vista em ROQUE, Miguel Prata. A dimensão transnacional do direito administrativo: uma visão cosmopolita das situações jurídico-administrativas. Lisboa: AAFDL, 2014. p. 657-671. lação portuguesa por ter reestruturado a maneira pela qual o Estado português concretizava suas contratações públicas $^{20}$.

Um dos principais aspectos a ser destacado no CCP diz respeito ao estabelecimento de novos critérios adjudicatórios que favorecessem os contratos públicos de maneira que estes pudessem promover a defesa do meio ambiente por meio do desenvolvimento sustentável e, ainda, a concretização de políticas sociais que garantissem, em longo prazo, a própria viabilidade financeira da socialidade $^{21}$. Em outras palavras, o CCP passou a dar a garantia legal ao Estado português de que este, em seus processos adjudicatórios, poderia buscar a concretização dos aspectos socioambientais estabelecidos pelas diretivas europeias - ou seja, poderia utilizar como critérios para a adjudicação não apenas o do preço mais baixo mas também o da sustentabilidade ecológica e social com base no critério da proposta economicamente mais vantajosa.

Especificamente no caso português, é na fase inicial do processo de formação do contrato público que as considerações ambientais e sociais devem estar presentes, já que espera-se a transparência durante todo o processo adjucatório. Nesse sentido o art. $36^{\circ}$ do CCP traz a decisão de contratar, que corresponde ao início do procedimento de contratação pública ${ }^{22}$, sendo este o momento em que, tendo-se por base o princípio da prossecução do interesse público, a entidade adjudicante deve incluir, em suas considerações, as questões socioambientais ${ }^{23}$.

20 Nesse sentido tem-se que o CCP "procurou repensar globalmente toda a legislação em matéria de procedimentos pré-contratuais a qual, para além de dispersa, estava recheada de incoerências, uma vez que correspondia a momentos de elaboração legislativa cronologicamente desfasados e, por isso, também, fruto de opções teóricas diversas e, muitas vezes, incompatíveis". A este respeito ver ESTORNINHO, Maria João. Curso de direito dos contratos públicos: por uma contratação pública sustentável. Coimbra: Almedina, 2014, p. 268-269; 288-2889.

21 ESTORNINHO, Maria João. Curso de direito dos contratos públicos: por uma contratação pública sustentável. Coimbra: Almedina, 2014. p. 291. No mesmo sentido fala-se na "sustentabilidade dos países, numa economia de mercado, [baseada] na tríplice vertente económica, ecológica e social, que seja compatível com a manutenção de um Estado social ou, dizendo de outro modo, com a sobrevivência de um Estado com um adequado grau de socialidade". NABAIS, José Casalta. Da sustentabilidade do Estado fiscal. In: NABAIS, José Casalta; SILVA, Suzana Tavares da (Coord.). Sustentabilidade fiscal em tempos de crise. Coimbra: Almedina, 2011. p. 24.

22 PORTUGAL. Procuradoria-Geral Distrital de Lisboa. Código dos Contratos Públicos. Decreto-Lei n. 18, de 29 de janeiro de 2008. Atualizada pelo Decreto-Lei n. 149, de 12 de julho 2012. Disponível em: <http://www.pgdlisboa.pt/leis/lei_mostra_articulado. php?nid=2063\&tabela=leis\&so_miolo=>. Acesso em: 20 jul. 2015. 23 ESTORNINHO, Maria João. Curso de direito dos contratos públicos: 
Como exemplos de critérios ambientais, a entidade adjudicante pode exigir a reutilização de determinados bens em vez de adquirir novos, ou ainda exigir a utilização de meios virtuais para comunicação em vez de meios impressos. Além disso, o próprio objeto do contrato pode ser vinculado a exigências ambientais, tais como a compra de papel 100\% reciclado. Ainda, destaca-se que outros aspectos socioambientais da contratação podem estar presentes no caderno de encargos e na definição das especificações técnicas, que são os locais específicos para a explicitação do mínimo social e ambientalmente exigido ${ }^{24}$.

Por sua vez, o art. $38^{\circ}$ do CCP traz a chamada decisão de escolha do procedimento ${ }^{25}$, a qual deve ser fundamentada, cabendo esta ao órgão competente para a decisão de contratar. É nesse momento que o contratante explicitará aos futuros possíveis contratados quais são as razões que o levaram a estabelecer os critérios social e ambientalmente apresentados na decisão de contratar.

Já o art. $40^{\circ}$ do CPP traz quais são as peças do procedimento e indica que o caderno de encargos é peça essencial em todos os procedimentos de contratação do Estado português. Assim, o art. $42^{\circ}$ trará a definição do caderno de encargos, indicando-o como "a peça do procedimento que contém as cláusulas a incluir no contrato a celebrar". É importante salientar que o n ${ }^{\circ} 6$ deste artigo traz, explicitamente, que "os aspectos da execução do contrato constantes das cláusulas do caderno de encargos podem dizer respeito a condições de natureza social ou ambiental relacionadas com tal execução"26.

No mesmo sentido, o art. 43, que fala acerca do caderno de encargos do procedimento de formação de contratos de empreitada, em seu $\mathrm{n}^{\circ} 5$, alíneas $c$ e $d$, traz que o projeto de execução deve ser acompanhado "dos estudos ambientais, incluindo a declaração de impacto

por uma contratação pública sustentável. Coimbra: Almedina, 2014. p. $430-431$.

24 ESTORNINHO, Maria João. Curso de direito dos contratos públicos: por uma contratação pública sustentável. Coimbra: Almedina, 2014. p. 431.

25 PORTUGAL. Procuradoria-Geral Distrital de Lisboa. Código dos Contratos Públicos. Decreto-Lei n. 18, de 29 de janeiro de 2008. Atualizada pelo Decreto-Lei n. 149, de 12 de julho 2012. Disponível em <http://www.pgdlisboa.pt/leis/lei_mostra_articulado. php?nid=2063\&tabela=leis\&so_miolo=> . Acesso em: 20 jul. 2015. 26 PORTUGAL. Procuradoria-Geral Distrital de Lisboa. Código dos Contratos Públicos. Decreto-Lei n. 18, de 29 de janeiro de 2008. Atualizada pelo Decreto-Lei n. 149, de 12 de julho 2012. Disponível em: <http://www.pgdlisboa.pt/leis/lei_mostra_articulado. php?nid=2063\&tabela=leis\&so_miolo=> . Acesso em: 20 jul. 2015. ambiental" e "dos estudos de impacto social, económico ou cultural" ${ }^{27}$, sob pena até de nulidade do caderno em caso de ausência de tais informações ${ }^{28}$. Pelo exposto, percebe-se, claramente, que o CCP dá ao administrador público a possibilidade de incluir, explicitamente, as considerações socioambientais que considerar pertinentes, desde que fundamentadas e desde que não infrinjam os princípios não só do direito português, mas, também, do direito europeu e mesmo do direito internacional.

Avança-se, agora, para o art. $49^{\circ}$, um dos mais importantes no processo de estabelecimento do caderno de encargos já que trata das especificações técnicas. Enquanto o $\mathrm{n}^{\mathrm{o}} 1$ desse art. faz referência explícita às diretivas de 2004 , em seu n ${ }^{\circ} 2$, alínea $c$, novamente, se verifica a referência a aspectos ambientais quando é afirmado que as especificações técnicas devem ser fixadas no caderno de encargos "em termos de desempenho ou de exigências funcionais, incluindo práticas e critérios ambientais, desde que sejam suficientemente precisas para permitir a determinação do objecto do contrato pelos interessados e a escolha da proposta pela entidade adjudicante" ${ }^{29}$.

Por sua vez, o n 7 e suas alíneas desse mesmo art. $49^{\circ}$ trazem que o caderno de encargos pode prever especificações pormenorizadas das especificações técnicas que porventura estejam ali presentes, especificamente quando estas forem fixadas em termos de desempenho ou de exigências funcionais que digam respeito a práticas e critérios ambientais. Além disso, importa destacar que os rótulos ecológicos europeus (ou outros análogos), quando forem exigidos, também precisam estar explícitos no caderno de encargos ${ }^{30}$.

27 PORTUGAL. Procuradoria-Geral Distrital de Lisboa. Código dos Contratos Públicos. Decreto-Lei n. 18, de 29 de janeiro de 2008. Atualizada pelo Decreto-Lei n. 149, de 12 de julho 2012. Disponível em: <http://www.pgdlisboa.pt/leis/lei_mostra_articulado. php?nid=2063\&tabela=leis\&so_miolo=>. Acesso em: 20 jul. 2015. 28 BASTOS, Filipe Brito. A escolha de critérios ambientais de adjudicação de contratos públicos: reflexões de Direito Administrativo nacional e europeu. Lisboa: ICJP, 2012, p. 6.

29 PORTUGAL. Procuradoria-Geral Distrital de Lisboa. Código dos Contratos Públicos. Decreto-Lei n. 18, de 29 de janeiro de 2008. Atualizada pelo Decreto-Lei n. 149, de 12 de julho 2012. Disponível em: <http://www.pgdlisboa.pt/leis/lei_mostra_articulado. php?nid=2063\&tabela=leis\&so_miolo=>. Acesso em: 20 jul. 2015. 30 PORTUGAL. Procuradoria-Geral Distrital de Lisboa. Código dos Contratos Públicos. Decreto-Lei n. 18, de 29 de janeiro de 2008. Atualizada pelo Decreto-Lei n. 149, de 12 de julho 2012. Disponível em: <http://www.pgdlisboa.pt/leis/lei_mostra_articulado. php?nid=2063\&tabela=leis\&so_miolo=>. Acesso em: 20 jul. 2015. 
O princípio da não discriminação está presente no $\mathrm{n}^{\circ} 12$ do art. $49^{\circ}$ ao impedir, explicitamente, a "fixação de especificações técnicas que façam referência a um fabricante ou uma proveniência determinados, a um processo específico de fabrico, a marcas, patentes ou modelos e a uma dada origem ou produção, que tenha por efeito favorecer ou eliminar determinadas entidades ou determinados bens". Já o no 14 traz a possibilidade de inclusão de critérios sociais no caderno de encargos, posto que exige que as especificações técnicas sejam fixadas, sempre que possível, de maneira a que os bens a adquirir ou as obras a executar possuam características que permitam a sua utilização por pessoas com deficiências $^{31}$.

Deve-se, ainda, ter em mente os critérios de adjudicação previstos no art. $74^{\circ}$ do $\mathrm{CCP}^{32}$, os quais apresentam-se como menos detalhados que aqueles referentes ao estabelecimento do caderno de encargos ${ }^{33}$. Entretanto, ainda que esse artigo do CPP traga que a adjudicação deve ser feita apenas com base no critério da proposta economicamente mais vantajosa ou com base no critério do preço mais baixo - ou seja, sem deixar explícita a possibilidade de uso de critérios socioambientais na escolha da proposta vencedora -, é importante destacar que a jurisprudência do Tribunal de Justiça da União Europeia ${ }^{34}$ já havia permitido que critérios ambientais pudessem vir

31 PORTUGAL. Procuradoria-Geral Distrital de Lisboa. Código dos Contratos Públicos. Decreto-Lei n. 18, de 29 de janeiro de 2008. Atualizada pelo Decreto-Lei n. 149, de 12 de julho 2012. Disponível em: <http://www.pgdlisboa.pt/leis/lei_mostra_articulado. php?nid=2063\&tabela=leis\&so_miolo=>. Acesso em: 20 jul. 2015. 32 PORTUGAL. Procuradoria-Geral Distrital de Lisboa. Código dos Contratos Públicos. Decreto-Lei n. 18, de 29 de janeiro de 2008. Atualizada pelo Decreto-Lei n. 149, de 12 de julho 2012. Disponível em: <http://www.pgdlisboa.pt/leis/lei_mostra_articulado. php?nid=2063\&tabela=leis\&so_miolo=>. Acesso em: 20 jul. 2015. 33 Esta afirmação é feita com base no disposto no $\mathrm{n}^{\circ} 1 \mathrm{do} \operatorname{art.} 75^{\circ}$, que faz referência a "factores e eventuais subfactores que densificam o critério de adjudicação da proposta economicamente mais vantajosa", contudo "sem enunciar quais factores e subfactores é que são admissíveis". BASTOS, Filipe Brito. A escolha de critérios ambientais de adjudicaşão de contratos públicos: reflexões de direito administrativo nacional e europeu. Lisboa: ICJP, 2012. p. 7.

34 BASTOS, Filipe Brito. A escolba de critérios ambientais de adjudicação de contratos públicos: reflexões de direito administrativo nacional e europeu. Lisboa: ICJP, 2012. p. 7. À página subsequente o autor afirma, inclusive, que a ausência de explicitação acerca de quais seriam os critérios e subcritérios para a definição de contratos públicos com características socioambientais na legislação comunitária anterior (diretiva 92/50) teria sido um dos motivos para a inclusão explícita dos mesmos nos artigos $55^{\circ}, \mathrm{n}^{\circ} 1$, alínea a e $53^{\circ}, \mathrm{n}^{\circ} 1$, alínea a, respectivamente das diretivas 2004/17/CE e 2004/18/CE, em consequência do Acórdão Concordia Bus Finland. a ser utilizados para a definição da proposta vencedora, desde que: a) os critérios estejam diretamente ligados ao objeto do contrato; b) a entidade adjudicante não tenha liberdade ilimitada, isto é, não seja discricionária em sua decisão; c) os critérios socioambientais sejam mencionados no anúncio e nos cadernos de encargos; e d) se respeitem os princípios fundamentais dos Tratados, nomeadamente os princípios da transparência, da igualdade e da não discriminação entre as propostas apresentadas ${ }^{35}$.

Por fim, no que concerne à qualificação dos candidatos, os arts. $179^{\circ}$ e $181^{\circ}$ do CCP, em seus respectivos $n^{\circ} 1$, trazem como critérios de seleção a capacidade técnica e financeira dos proponentes ${ }^{36}$. Neste ponto é possível integrar, como requisitos mínimos, a experiência, a competência e a capacidade de gestão ambiental, de maneira a só avançarem "para a fase de apresentação de propostas e de adjudicação aqueles que ofereçam garantias de integrar a componente ambiental na execução do contrato" ${ }^{37}$. Busca-se, dessa maneira, garantir que aquele que venha a ser o eventual vencedor do concurso não prejudique o mesmo posteriormente por não ter a capacidade técnica necessária para concretizar aquilo que foi proposto, o que traria prejuízos não apenas ao Estado mas, principalmente, à sociedade, já que tal fato ocasionaria a realização de novo concurso, com a respectiva perda de tempo e de dinheiro dos contribuintes.

\subsection{As diretivas de 2014: a contratação pública em tempos de crise econômica}

O contexto de crise econômica pelo qual passaram inúmeros Estados-membros da União Europeia no início da década de 2010, associado às consequentes pressões políticas, sociais e ambientais para a manutenção no nível de vida parece ser, sem sombra de dúvidas, um dos motivos que levou à necessidade de revisão das direti-

35 ESTORNINHO, Maria João. Curso de direito dos contratos públicos: por uma contratação pública sustentável. Coimbra: Almedina, 2014. p. 436; BASTOS, Filipe Brito. A escolha de critérios ambientais de adjudicaşão de contratos públicos: reflexões de direito administrativo nacional e europeu. Lisboa: ICJP, 2012. p. 8.

36 PORTUGAL. Procuradoria-Geral Distrital de Lisboa. Código dos Contratos Públicos. Decreto-Lei n. 18, de 29 de janeiro de 2008. Atualizada pelo Decreto-Lei n. 149, de 12 de julho 2012. Disponível em: <http://www.pgdlisboa.pt/leis/lei_mostra_articulado. php?nid=2063\&tabela=leis\&so_miolo=> . Acesso em: 20 jul. 2015. 37 ESTORNINHO, Maria João. Curso de direito dos contratos públicos: por uma contratação pública sustentável. Coimbra: Almedina, 2014. p. 433. 
vas de 2004. Nesse sentido, tal processo de revisão tinha como objetivo a promoção do emprego como decorrência do crescimento econômico em associação à proteção do meio ambiente, esperando-se que tal objetivo fosse atingido por meio da simplificação e da flexibilização das regras concernentes à contratação pública ${ }^{38}$. Por outras palavras, esperava-se que o Estado fosse capaz de atuar como instituição estimuladora do desenvolvimento econômico por meio de suas políticas públicas, sendo a contratação pública sustentável um dos principais mecanismos de concretização das mesmas devido ao papel estratégico que poderia ter em contexto de crise ${ }^{39}$.

Nesse contexto, o processo de revisão das diretivas de 2004 se deu, principalmente, por meio da concretização das orientações constantes no livro chamado Comprar ecológico! - Manual de contratos públicos ecológicos, de 2011. Por sua vez, em 2012 foi lançado o livro Compra social - Guia para ter em conta os aspectos sociais nos concursos públicos $^{40}$. Além disso, é importante destacar que as propostas das novas diretivas foram criadas no âmbito da estratégia Europa $2020^{41}$ e se fundamentam em três objetivos primordiais para o consórcio europeu: primeiro, o desenvolvimento de uma nova economia fundamentada no conhecimento e na inovação; segundo, incentivar novas fontes de energia de maneira a reduzir o uso de fontes fósseis, utilizando-se os recursos de maneira eficaz e competitividade; por fim, incentivar o emprego em níveis elevados ao mesmo tempo em que se mantenha a coesão social ${ }^{42}$.

38 PEREIRA, Pedro Matias; FRANCO, João Soares. A adjudicação de contratos públicos em contexto de crise. Revista de contratos públicos, Coimbra, n. 5, maio/ago. 2012. p. 145-146.

39 Nesse sentido tem-se que "os contratos públicos podem (e devem) servir à realização de outros fins que não aqueles que emergem imediatamente do seu objeto (obter um serviço, comprar um bem), como, por exemplo, a consideração de uma certa política ambiental ou a preocupação com determinado problema social". PEREIRA, Pedro Matias; FRANCO, João Soares. A adjudicação de contratos públicos em contexto de crise. Revista de contratos públicos, Coimbra, n. 5, maio/ago. 2012. p. 154.

40 "As diretivas de 2004 não conseguiram esclarecer totalmente como a sustentabilidade poderia ser integrada no âmbito dos contratos públicos, justificando assim a necessidade sentida pela Comissão de intervir mais. Por meio de mecanismos de soft law, a Comissão tentou guiar os adquirentes no caminho da sustentabilidade". DRAGOS, Dacian C.; NEAMTU, Bogdana. Sustainable public procurement in the EU: experiences and prospects. In: LICHERE, Francois; CARANTA, Roberto; TREUMER, Steen (Eds.). Novelties in the 2014 Directive on public procurement. DJØF Publishing, 2014. Available at: <http://ssrn.com/abstract=2488047>. Accessed: 22 jul. 2015. p. 7. 41 Acerca da estratégia Europa 2020 ver o item 2.1 à frente neste texto.

42 ESTORNINHO, Maria João. Curso de direito dos contratos públicos:
Esperava-se, portanto, que os contratos públicos fossem utilizados como ferramentas eficazes no sentido de estimular ainda mais o surgimento de contratos públicos socioambientalmente sustentáveis que fossem capazes de responder aos desafios pelos quais passava a Europa naquele momento ${ }^{43}$. Nesse contexto buscou-se agregar aos contratos públicos dois novos princípios - quais sejam, o da flexibilidade e o da sustentabilidade, tanto do ponto de vista social quanto ambiental ${ }^{44}-$ de maneira a fazer com que o desafio da continuidade do desenvolvimento social em adequação à preservação do meio ambiente - ambos tendo como pano de fundo a crise econômica daquele momento - pudesse ser vencido ${ }^{45}$.

Estabeleceu-se que como sugestões para a contratação pública flexível e sustentável a entidade adjudicante pudesse levar em consideração: a) o cálculo dos custos ao longo do ciclo de vida dos produtos, dos serviços ou das obras a adquirir; b) o procedimento de produção dos produtos ou com a prestação dos serviços adquiridos; c) o uso de rótulos específicos que certifiquem características ambientais ou sociais; d) a presença de sanções quando da violação da legislação social, laboral ou ambiental vinculativa; e) a presença de elementos que favoreçam a inovação tecnológica a partir da contratação pública ${ }^{46}$.

por uma contratação pública sustentável. Coimbra: Almedina, 2014. p. 117.

43 BASTOS, Filipe Brito. A escolba de critérios ambientais de adjudicaşão de contratos públicos: reflexões de direito administrativo nacional e europeu. Lisboa: ICJP, 2012. p. 3.

44 Apesar de destacados os aspectos social e ambiental da sustentabilidade, torna-se imperioso destacar, também, o aspecto econômico da sustentabilidade, já que o modelo de Estado atual - o Estado fiscal - precisa de recursos para garantir os dois primeiros aspectos. Neste sentido tem-se que "efectivamente impõe-se que a sustentabilidade financeira seja considerada no domínio mais amplo da sustentabilidade económica, ecológica e social. Pois a sustentabilidade neste sentido amplo não pode deixar de ser tida em devida conta pela sustentabilidade financeira, que [...] mais não é do que a sustentabilidade fiscal do Estado. Efectivamente, o orçamento do Estado, enquanto programa da política financeira em números, que suporta e espelha uma dada sustentabilidade, não pode deixar de ser visto como um instrumento, ao mesmo tempo central e fundamental de um equilíbrio global nos domínios económico, ecológico e social”. A este respeito ver NABAIS, José Casalta. Da sustentabilidade do Estado fiscal. In: NABAIS, José Casalta; SILVA, Suzana Tavares da (Coord.). Sustentabilidade fiscal em tempos de crise. Coimbra: Almedina, 2011. p. 24-27.

45 ESTORNINHO, Maria João. Curso de direito dos contratos públicos: por uma contratação pública sustentável. Coimbra: Almedina, 2014. p. 119.

46 ESTORNINHO, Maria João. Curso de direito dos contratos públicos: por uma contratação pública sustentável. Coimbra: Almedina, 2014. p. $438-440$. 
Como consequência das propostas, três novas diretivas - a diretiva 2014/24/UE, que revisou e substituiu a diretiva 2004/18/CE (setores clássicos) ${ }^{47}$; a diretiva 2014/25/UE, que revisou e substituiu a diretiva 2004/17/CE (setores especiais) ${ }^{48}$; e a nova diretiva 2014/23/UE ${ }^{49}$, que trata dos contratos de concessão - foram aprovadas pelo Parlamento Europeu e pelo Conselho em 2014. Conforme o texto das próprias diretivas, os Estados-membros têm até abril de 2016 para realizarem a transposição das novas regras a seus ordenamentos jurídicos, à exceção das regras referentes à e-contratação, cujo prazo vai até outubro de 2018.

No que concerne aos aspectos ambientais, as diretivas de 2014 possuem, entre outras, as seguintes características ${ }^{50}$ :

A existência de uma cláusula ambiental horizontal. Essa

47 UNIÃO EUROPEIA. Diretiva 2014/24/UE do Parlamento Europeu e do Conselho, de 26 de fevereiro de 2014. Relativa aos contratos públicos de obras, fornecimentos ou serviços e que revoga a Diretiva 2004/18/CE. Jornal Oficial da União Europeia, n. L 94/65, de 28 de março de 2014. Disponível em: <http://eur-lex.europa. eu/legal-content/PT/TXT/?uri=CELEX:32014L0024>. Acesso em: 20 jul. 2015.

48 UNIÃO EUROPEIA. Diretiva 2014/24/UE do Parlamento Europeu e do Conselho, de 26 de fevereiro de 2014. Relativa aos contratos públicos de obras, fornecimentos ou serviços e que revoga a Diretiva 2004/18/CE. Jornal Oficial da União Europeia, n. L 94/65, de 28 de março de 2014. Disponível em: < http://eur-lex.europa. $\mathrm{eu} /$ legal-content/PT/TXT/?uri=CELEX:32014L0024>. Acesso em: 20 jul. 2015.

49 UNIÃO EUROPEIA. Diretiva 2014/24/UE do Parlamento Europeu e do Conselho, de 26 de fevereiro de 2014. Relativa aos contratos públicos de obras, fornecimentos ou serviços e que revoga a Diretiva 2004/18/CE. Jornal Oficial da União Europeia, n. L 94/65, de 28 de março de 2014. Disponível em: <http://eur-lex.europa. eu/legal-content/PT/TXT/?uri=CELEX:32014L0024>. Acesso em: 20 jul. 2015. Destaca-se que a diretiva 2014/23/UE é resultado de uma proposta específica de diretiva para os contratos de concessão. Neste sentido tem-se que concessões são contratos nos quais "o Estado assume sobretudo tarefas de garantia e de controlo, uma vez que a sua tradicional responsabilidade de execução tende a ser substituída por uma responsabilidade de garantia da prestação ou, até, por uma mera responsabilidade de controlo ou de fiscalização". Acrescente-se ainda que "as concessões são atos imputáveis ao Estado, pelos quais uma autoridade pública confia a um terceiro - seja por ato contratual ou por ato unilateral, com consentimento de terceiro - a gestão total ou parcial de serviços que relevem normalmente da sua responsabilidade e pelos quais o terceiro assume os riscos da exploração". Acerca destas definições ver ESTORNINHO, Maria João. Curso de direito dos contratos públicos: por uma contratação pública sustentável. Coimbra: Almedina, 2014. p. 121-126, passim.

50 COMISSÃO EUROPEIA. Public procurement reform: environmental aspects. p. 1-2. Available at: $<$ http://ec.europa.eu/internal_ market/publicprocurement/modernising_rules/reform_proposals/index_en.htm>. Accessed: 20 jul. 2015. cláusula implica o cumprimento, por parte das empresas, das obrigações ambientais decorrentes do direito nacional, do direito europeu e do direito internacional, de maneira que aquela empresa que não respeitar tais obrigações ambientais possa ser excluída do processo de adjudicação. Destaca-se, ainda, que o contrato poderá não ser adjudicado à empresa que apresente a melhor proposta se esta não cumprir as obrigações ambientais aplicáveis, ao mesmo tempo em que estabelece que uma proposta que seja anormalmente baixa para as obras, produtos ou serviços a adquirir por não cumprir as obrigações ambientais deva ser rejeitada.

Definem disposições sobre a utilização de rótulos ecológicos. Os rótulos ecológicos correspondem a um documento, certificado ou atestado que venha por confirmar que determinado produto cumpre condições e requisitos de qualidade estabelecidos e predefinidos. Nesse contexto, às entidades adjudicantes é dada a possibilidade de exigirem tais rótulos ecológicos ao estabelecerem as características do que desejam adquirir. O uso de tais rótulos pressupõe os seguintes critérios: a) todos os requisitos a cumprir para obter o rótulo em questão devem estar associados às obras, produtos ou serviços específicos a adquirir; b) os rótulos devem ser estabelecidos por organismos independentes de acordo com procedimentos transparentes, de maneira a poderem vir a participar todos os interessados, nomeadamente organismos governamentais, consumidores, fabricantes, distribuidores e organizações não governamentais; c) os rótulos devem basear-se em critérios objetivos e não discriminatórios e estar à disposição de todas as partes interessadas; e d) se uma empresa não conseguir obter um rótulo a tempo, os adquirentes públicos devem aceitar rótulos equivalentes, tendo em vista o princípio da igualdade.

Estabelecem considerações sobre o processo de produção do produto contratado. Em outras palavras, significa dizer que a entidade adjudicante pode, desde que resguardados os princípios da contratação pública, definir "todos os fatores do processo de produção, abastecimento ou comercialização, mesmo que tais fatores não façam parte da substância material do produto". Por exemplo, a entidade adjudicante pode exigir, ao descrever do ponto de vista técnico os produtos ou serviços que pretende adquirir, que seu fabrico não envolva produtos químicos tóxicos ou que sejam fabricados/prestados utilizando máquinas eficientes em termos energéticos, ou, ainda, avaliar os aspectos econômicos com base nos aspectos ambientais (por exemplo, se determinados 
livros foram impressos em papel reciclado ou papel fabricado a partir de madeira sustentável).

Obrigam a realização de análises acerca do custo do ciclo de vida ${ }^{51}$. As diretivas abrem a possibilidade para que as entidades adjudicantes coloquem como critério técnico a análise do custo de vida das obras, dos produtos ou dos serviços que serão adquiridos, abrangendo não apenas os custos internos, próprios das obras, dos produtos ou dos serviços, mas também os custos relacionados com aspetos ambientais ${ }^{52}$, tais como o nível das emissões de gases de efeito estufa, a poluição causada pela extração de matérias-primas utilizadas no produto ou causada pelo próprio produto ou pelo seu fabrico.

Já no que concerne aos aspectos sociais das diretivas de 2014, devem ser destacados os seguintes aspectos, entre outros ${ }^{53}$ :

A existência de uma cláusula social horizontal análoga à cláusula ambiental horizontal (explicitada acima);

A entidade adjudicante pode estabelecer critérios sociais, tais como o estímulo à contratação de determinado número de pessoas desempregadas com vistas à (re) inserção social, para produzir os produtos ou prestar os serviços objetos do contrato - desde que tais critérios sociais se refiram exclusivamente ao contrato em curso, não sendo passíveis de serem exigidos como uma política empresarial de longo prazo;

Os Estados-membros podem adjudicar os contratos às propostas que correspondam a todos os critérios de qualidade previamente estabelecidos, tais como a acessibilidade, a continuidade e a sustentabilidade dos serviços propostos, que considerem determinantes para o

51 Um estudo detalhado acerca desse critério, inclusive com a definição de metodologias acerca da definição do próprio custo do ciclo de vida, está disponível em DRAGOS, Dacian C.; NEAMTU, Bogdana. Sustainable public procurement: life cycle costing (LCC) in the new EU Directive proposal. European Public Procurement and PPP Law Review, 2013. Available in: <http://ssrn.com/ abstract $=2488021>$. Access: 22 jul. 2015.

52 Tais custos só podem ser considerados se os mesmos puderem ser objetivamente determinados e quantificados. Da mesma maneira, tais custos devem ser gerais, válidos para qualquer contratação pública, e não apenas para o concurso em questão. COMISSÃO EUROPEIA. Public procurement reform: environmental aspects. p. 1-2. Available in <http://ec.europa.eu/internal_market/publicprocurement/modernising_rules/reform_proposals/index_en.htm $>$. Access: 20 jul. 2015. p. 2.

53 COMISSÃO EUROPEIA. Public procurement reform: social aspects of the new rules. Available at: <http://ec.europa.eu/internal_market/publicprocurement/modernising_rules/reform_proposals/index_en.htm>. Accessed: 20 jul. 2015. p. 1-3. serviço em causa.

As empresas que infringirem certas regras ou obrigações são excluídas dos contratos públicos, especialmente em caso de condenação por não pagamento de impostos ou contribuições para a segurança social e em caso de não cumprimento da cláusula social horizontal anteriormente referida.

Também, no âmbito da subcontratação, continua exigível o cumprimento das obrigações ambientais, sociais e laborais que decorrem do direito europeu, do direito nacional, das convenções coletivas ou do direito internacional, desde que na fase de concurso as empresas indiquem qual parte do contrato que não tencionam serem elas próprias a executar, mas pretendem confiar a terceiros.

Ao que se percebe, as diretivas de 2014 correspondem ao verdadeiro avanço em direção às contratações públicas efetivamente sustentáveis, já que buscam trazer maior grau de detalhamento dos critérios socioambientais quando em comparação com as diretivas de 2004 além de trazerem novos avanços frente a estas no que concerne ao próprio processo de adjudicação ${ }^{54}$. Nesse sentido buscou-se dar aos Estados-membros as ferramentas necessárias para que políticas de cunho socioambientais fossem efetivamente postas em prática, o que se torna relevante ao se ter, por um lado, a perspectiva futura conforme definida pela estratégia Europa 2020 e, por outro, ao se considerar a situação atual de crise financeira do Estado social europeu ${ }^{55}$.

54 Em síntese os avanços são os seguintes, além da própria inclusão dos critérios socioambientais no procedimento de contratação: a) Alterações nos limiares dos concursos que exigem sua publicação no Jornal Oficial da União Europeia; b) A aposta nos meios eletrônicos de contratação; c) Incentivo e maior apoio às pequenas e médias empresas; d) Revisão e alargamento dos motivos de exclusão de operadores econômicos participantes dos concursos; e) O estabelecimento de um novo procedimento - as parcerias para inovação. Os detalhes destes avanços estão em RODRIGUES, Carlos Sérgio Madureira. Entre a contratação pública ecológica e a contratação pública sustentável: compreender o presente, transpor o futuro. 2014. 153 f. Dissertação (Mestrado) - Faculdade de Direito, Universidade de Coimbra, Coimbra, 2014. Disponível em: <http://hdl.handle. net/10316/28443>. Acesso em: 18 jul. 2015. p. 75-82.

55 Existem, contudo, críticas às diretivas de 2014. Rodrigues afirma que as diretivas correspondem a um "passo tímido" em direção à maior proteção socioambiental, já que elas continuam se utilizando da racionalidade econômica para o estabelecimento dos contratos públicos - ainda que o autor reconheça que as considerações ambientais e sociais apareçam misturadas às considerações econômicas. $\mathrm{Na}$ visão do autor a importância da esfera econômica está no próprio texto da diretiva, quando designa por "proposta economicamente mais vantajosa" aquela que permite maior inclusão de critérios so- 


\section{A CONTRATAÇÃo PÚblica SUSTENTÁVEL EM CONTEXTO DE CRISE}

As diretivas de 2014 trouxeram inúmeras inovações acerca do tema da contratação pública sustentáve ${ }^{\overline{ }}$. Nesse sentido, uma vez transpostas para o ordenamento jurídico interno dos Estados-membros da União Europeia, espera-se que estes possam se valer dos mecanismos previstos nas diretivas para fazer avançar a proteção ambiental ao mesmo tempo em que também buscam a garantia dos aspectos sociais envolvidos, nomeadamente a garantia de elevados níveis de emprego e, ainda, a inclusão de grupos sociais menos favorecidos economicamente.

Contudo, os gastos com a contratação pública sustentável parecem vir a ser questionados quando se verifica que os Estados-membros da União Europeia, de maneira geral - e alguns de maneira mais específica, nomeadamente Irlanda, Grécia, Chipre e Portugal ${ }^{57}$ - passaram,

cioambientais. Por outras palavras, significa dizer que estes critérios seriam secundários, já que corresponderiam à base para se escolher a melhor proposta em termos econômicos. $\mathrm{O}$ autor sugere que a transposição destas diretivas para o ordenamento jurídico português ocorra de maneira a se adjudicar com base na proposta "sustentavelmente" mais vantajosa, ou ainda com base na "proposta mais vantajosa em termos de sustentabilidade". A este respeito ver RODRIGUES, Carlos Sérgio Madureira. Entre a contratação pública ecológica e a contratação pública sustentável: compreender o presente, transpor o futuro. 2014. 153 f. Dissertação (Mestrado) - Faculdade de Direito, Universidade de Coimbra, Coimbra, 2014. Disponível em: <http://hdl.handle. net/10316/28443>. Acesso em: 18 jul. 2015. p. 126-7.

56 Por contratação pública "sustentável" entende-se aquela que leva em consideração aspectos ambientais e sociais, enquanto a contratação pública "verde" está diretamente vinculada apenas àquelas que consideram critérios de sustentabilidade ambiental. Maior ênfase tem sido dada pela doutrina às contratações "verdes", não às "sustentáveis". Acerca desta distinção ver ALENCASTRO, Maria Alice Cruz; SILVA, Edson Vicente da; LOPES, Ana Maria D’Ávila. Contratações sustentáveis na administração pública brasileira: a experiência do Poder Executivo federal. Revista de Administração Pública, Rio de Janeiro, v. 48, n. 1, jan./fev. 2014. Disponível em: <http:/ / dx.doi.org/10.1590/S0034-76122014000100009>. Acesso em: 18 jul. 2015. p. 215.

57 Um breve resumo acerca das origens da crise econômica e de seus impactos em termos mundiais - em conjunto com a influência do fenômeno da globalização neste processo - pode ser visto em MEDEIROS, Rui. A Constituição Portuguesa num contexto global. Lisboa: Universidade Católica, 2015. p. 75-8. A respeito especificamente da crise econômica em Portugal tem-se que "a falta de crescimento econômico aliada à necessidade e imposição externa de correcção dos graves desequilíbrios acumulados das contas públicas, têm conduzido a uma carga fiscal próximo do limite que não é possível manter por muito tempo. [...] Daí que a sustentabilidade o Estado fiscal actual não disponha de outra alternativa efectiva senão a da redução muito significativa das despesas públicas de modo a restabelecer ou ainda estão a passar, por situação de crise econômica, em que surgem fortes restrições aos gastos públicos com o objetivo de sanear as contas destes Estados.

Torna-se necessário, portanto, apresentar qual o ambiente que levou ao próprio desenvolvimento das diretivas de 2014 - nomeadamente a estratégia Europa 2020. Em consonância, é necessário compreender a situação específica pela qual passou Portugal no início da década de 2010 - está-se aqui a referir-se ao Memorando de Políticas Econômicas e Financeiras - para que, em seguida, seja feita uma análise acerca do papel do Estado no que concerne à contratação pública sustentável em um contexto de crise econômica mundial.

\subsection{A estratégia Europa 2020}

O documento intitulado Europa 2020 - Estratégia para um crescimento inteligente, sustentável e inclusivo (doravante chamado de estratégia Europa 2020) corresponde a uma Comunicação feita pela Comissão Europeia em 03 de março de 2010 e que buscava apresentar rumos para a revitalização da economia europeia, já que naquele momento o mundo encontrava-se no auge da crise econômica. Nesse sentido, a estratégia Europa 2020 estabeleceu três prioridades - o crescimento inteligente, o crescimento sustentável e o crescimento inclusivo - das quais chama a atenção, para os objetivos deste texto, a segunda, sobre crescimento sustentável - ainda que esteja claro no documento que as três prioridades reforçam-se umas às outras. Assim, o crescimento sustentável tem por objetivo "promover uma economia mais eficiente em termos de utilização dos recursos, mais ecológica e mais competitiva" 58 .

Tendo-se em vista os aspectos sociais e ambientais da proposta, espera-se que $75 \%$ da população de idade compreendida entre 20 e 64 anos esteja empregada; que $3 \%$ do PIB da UE seja investido em pesquisa (investigação) e desenvolvimento; que os objetivos em matéria

um equilíbrio adequado às forças da nossa economia de mercado para gerar resultados tributáveis, como à capacidade contributiva dos contribuintes no quadro de um Estado que possa ainda ser tido por Estado social" (grifo nosso). A este respeito ver NABAIS, José Casalta. Da sustentabilidade do Estado fiscal. In: NABAIS, José Casalta; SILVA, Suzana Tavares da (Coord.). Sustentabilidade fiscal em tempos de crise. Coimbra: Almedina, 2011. p. inicial - final. p. 55.

58 COMISSÃO EUROPEIA. Europa 2020: estratégia para um crescimento inteligente, sustentável e inclusivo, 2010. Disponível em: <http://eur-lex.europa.eu/LexUriServ/LexUriServ.do?uri=C OM:2010:2020:FIN:PT:PDF>. Acesso em: 20 jul. 2015. p. 5. 
de clima/energia "20/20/20"59 devem ser cumpridos (incluindo uma subida para 30\% do objetivo para a redução das emissões, se as condições o permitirem); que a taxa de abandono escolar precoce seja inferior a $10 \%$ e pelo menos $40 \%$ da geração mais jovem disponha de um diploma de ensino superior; e que 20 milhões de pessoas devam deixar de estar sujeitas ao risco de pobreza $^{60}$.

Para a concretização de tais objetivos, e atendo-se aos aspectos socioambientais, a Comissão destaca a concretização de sete iniciativas, dentre as quais se destaca a criação de um espaço europeu que seja ambientalmente eficiente por meio da dissociação entre crescimento econômico e uso intensivo de recursos naturais, especialmente aqueles que tenham como fonte de energia combustíveis fósseis. Da mesma maneira, espera-se que tal espaço europeu utilize cada vez mais fontes de energia renováveis, especialmente por meio da modernização do setor de transportes e da promoção da eficiência energética ${ }^{61}$.

A Comunicação reconhece que, sendo a União Europeia composta por 28 Estados-membros, a concretização das propostas não pode ser feita de maneira única, já que a diversidade é grande. Nesse sentido, os objetivos da União devem ser concretizados por meio do estabelecimento de objetivos nacionais, os quais terão cada um sua própria "trajetória", de maneira que cada Estado-membro possa, com base em sua própria situação específica, atuar no sentido de concretizar os objetivos globais da União ${ }^{62}$. Em outras palavras, a Comunicação preza pelo princípio da descentralização

59 Os objetivos “20/20/20" são os seguintes: "Reduzir as emissões de gases com efeito de estufa em pelo menos $20 \%$ relativamente aos níveis de 1990, ou em 30\%, se estiverem reunidas as condições necessárias; aumentar para $20 \%$ a quota de energias renováveis no nosso consumo final energético e aumentar em $20 \%$ a eficiência energética" COMISSÃO EUROPEIA. Europa 2020: estratégia para um crescimento inteligente, sustentável e inclusivo. 2010. p. 13. Disponível em: < http://eur-lex.europa.eu/LexUriServ/LexUriServ.do ?uri=COM:2010:2020:FIN:PT:PDF>. Acesso em: 20 jul. 2015.

60 COMISSÃO EUROPEIA. Europa 2020: estratégia para um crescimento inteligente, sustentável e inclusivo, 2010. Disponível em: <http://eur-lex.europa.eu/LexUriServ/LexUriServ.do?uri=C OM:2010:2020:FIN:PT:PDF>. Acesso em: 20 jul. 2015p. p. 5.

61 COMISSÃO EUROPEIA. Europa 2020: estratégia para um crescimento inteligente, sustentável e inclusivo, 2010. Disponível em: <http://eur-lex.europa.eu/LexUriServ/LexUriServ.do?uri=C OM:2010:2020:FIN:PT:PDF>. Acesso em: 20 jul. 2015p. p. 6.

62 COMISSÃO EUROPEIA. Europa 2020: estratégia para um crescimento inteligente, sustentável e inclusivo, 2010. Disponível em: <http://eur-lex.europa.eu/LexUriServ/LexUriServ.do?uri=C OM:2010:2020:FIN:PT:PDF>. Acesso em: 20 jul. 2015p. p. 14. executiva, já que estabelece objetivos que precisam ser atingidos tanto pela própria União - objetivos estes de escala mais "global" - quanto pelos Estados-membros, que são responsáveis pela concretização de objetivos locais.

Antes de se verificar quais são as propostas específicas para Portugal, é interessante destacar os detalhes propostos pela Comissão a respeito do eixo referente ao crescimento sustentável. Aqui a Comissão sugere fortemente a luta contra as alterações climáticas, já que a melhor utilização dos recursos naturais permitiria redução da emissão de gases de efeito estufa bem como a realização de poupanças e, ainda, estimularia o crescimento econômico. Ao mesmo tempo, e em conformidade com tal objetivo, a Comissão propôs a busca pela utilização de energia limpa e eficiente, que poderia resultar em uma economia de 60 mil milhões de euros até 2020 , além de contribuir para a criação de até um milhão de novas vagas de emprego ${ }^{63}$.

É importante, ainda, destacar que a estratégia Europa 2020 deu início ao processo que desembocaria na atualização das diretivas de 2004 - e que resultou nas diretivas de 2014, conforme já explicitado -, especialmente ao propor a inclusão, no âmbito das contratações públicas, do critério do custo de vida do produto, o que veio a permitir às entidades adjudicantes o estabelecimento de critérios socioambientais de médio-longo prazo. Da mesma forma, estabeleceu-se a possibilidade de se utilizar como critério o método de produção dos bens e/ ou serviços requeridos, também com o objetivo de promover a proteção ambiental. Por fim, no aspecto social a estratégia sugeriu a implementação de mecanismos que permitissem a inclusão profissional e social de portadores de necessidades especiais (deficientes) ${ }^{64}$.

Como proposta para atingir tais objetivos, a Comissão sugere aquilo que chama de "iniciativas emblemáticas". A primeira delas, intitulada Uma Europa eficiente em termos de recursos e que é apresentada como sendo de responsabilidade da própria Comissão, a nível da União

63 COMISSÃO EUROPEIA. Europa 2020: estratégia para um crescimento inteligente, sustentável e inclusivo. 2010. Disponível em: <http://eur-lex.europa.eu/LexUriServ/LexUriServ.do?uri=C OM:2010:2020:FIN:PT:PDF>. Acesso em: 20 jul. 2015p. p. 18.

64 MATEI, Ani I.; MATEI, Lucica. Modernisation of the public procurement market. Towards a strategy of public marketing specific on the single market. Societal Innovations for Global Growth; Stream C: National Sustainable Development under Globalization Conditions, 2012. V. 1. Available in: <http://ssrn.com/abstract $=2135420>$. Access: 22 jul. 2015. p. 6. 
Europeia, traz, dentre outras, a necessidade de "reforçar um quadro para a utilização dos instrumentos baseados no mercado (por exemplo comércio de licenças de emissão, reforma da tributação da energia, enquadramento em matéria de auxílios estatais, promoção de um maior recurso aos contratos públicos ecológicos)" ${ }^{\prime 65}$.

Por sua vez, sugerem-se, como tarefas específicas dos Estados-membros, no âmbito da iniciativa Uma Europa eficiente em termos de recursos, o abandono gradual das "subvenções prejudiciais de um ponto de vista ecológi$\mathrm{co}$, limitando as excepções às pessoas com necessidades sociais" bem como a utilização de "instrumentos baseados no mercado, tais como incentivos fiscais e contratos públicos, para adaptar os métodos de produção e de consume". Sugere-se, também, o uso da "regulamentação, normas de desempenho ambiental dos edifícios e instrumentos baseados no mercado, tais como a tributação, as subvenções e os contratos públicos, para reduzir o consumo de energia e de recursos, e utilizar os fundos estruturais para investir na eficiência energética dos edifícios públicos e na melhoria de eficiência da reciclagem" $"$.

A segunda iniciativa, intitulada Uma politica industrial para a era da globalização, também traz ações a serem realizadas tanto pela própria Comissão quanto pelos Estados-membros. Como responsabilidade da Comissão, e no que concerne aos contratos públicos, destaca-se o desenvolvimento de "uma abordagem horizontal relativamente à política industrial que combine diferentes instrumentos de política (por exemplo, regulamentação inteligente, regras modernas em matéria de contratos públicos e auxílios estatais e normalização)", bem como a promoção de "tecnologias e métodos de produção que reduzam a utilização de recursos naturais e aumentar o investimento no patrimônio natural da UE". Aos Estados-membros, no âmbito dessa iniciativa, compete "melhorar o ambiente empresarial, nomeadamente para as PME inovadoras, em especial através de contratos públicos para apoiar os incentivos à inovação" ${ }^{\text {"67 }}$.

65 COMISSÃO EUROPEIA. Europa 2020: estratégia para um crescimento inteligente, sustentável e inclusivo. 2010. Disponível em: <http://eur-lex.europa.eu/LexUriServ/LexUriServ.do?uri=C OM:2010:2020:FIN:PT:PDF>. Acesso em: 20 jul. 2015p. p. 18.

66 COMISSÃO EUROPEIA. Europa 2020: estratégia para um crescimento inteligente, sustentável e inclusivo, 2010. Disponível em: <http://eur-lex.europa.eu/LexUriServ/LexUriServ.do?uri=C OM:2010:2020:FIN:PT:PDF>. Acesso em: 20 jul. 2015p. p. 19.

67 COMISSÃO EUROPEIA. Europa 2020: estratégia para um crescimento inteligente, sustentável e inclusivo, 2010. Disponível
No que concerne às ações do Estado português rumo à estratégia Europa 2020, a Comissão Europeia afirma que Portugal concluiu com êxito o seu programa de ajustamento econômico em 2014, tendo tido sucesso tanto no ajuste econômico quanto no ajuste de suas políticas públicas, e está atualmente submetido à "vigilância pós-programa". Apesar disso, informa ainda que o país sofre com desajustes macroeconômicos que são resultantes do alto nível de endividamento, tanto interno quanto externo, além do perigo representado pela baixa taxa de crescimento e pelo alto índice de desemprego ${ }^{68}$.

Neste contexto a Comissão publicou em 13 de maio de 2015 uma Recomendação relativa ao Programa Nacional de Reformas para 2015 de Portugal e que formula um Parecer do Conselho sobre o Programa de Estabilidade para 2015 de Portugal. A Comissão afirma, em relação ao item 5 do documento, no âmbito das concessões, que o Estado português precisa aumentar a transparência e acelerar as medidas referentes às concessões, especialmente no setor de transportes, bem como em relação às parcerias público-privadas a nível local e regional ${ }^{69}$.

\subsection{O memorando de entendimento sobre as condicionalidades de política econômica de Portugal e as subsequentes alterações no ordenamento jurídico português}

É de conhecimento comum o processo que desencadeou a crise econômica iniciada em 2008, com a falência do banco norte-americano de investimentos Lehman Brothers por ser o estopim da crise econômica. Inicialmente vinculada ao setor imobiliário americano, a crise se espalhou para os setores bancário e financeiro americanos e daí para o restante do mundo, cabendo aos Estados socorrerem o sistema econômico mundial ${ }^{70}$.

em: <http://eur-lex.europa.eu/LexUriServ/LexUriServ.do?uri=C OM:2010:2020:FIN:PT:PDF>. Acesso em: 20 jul. 2015. p. 20.

68 COMISSÃO EUROPEIA. Europa 2020: estratégia para um crescimento inteligente, sustentável e inclusivo, 2010. Disponível em: <http://eur-lex.europa.eu/LexUriServ/LexUriServ.do?uri=C OM:2010:2020:FIN:PT:PDF>. Acesso em: 20 jul. 2015

69 COMISSÃO EUROPEIA. Recomendação do Conselho relativa ao Programa Nacional de Reformas para 2015 de Portugal e que formula um Parecer do Conselho sobre o Programa de Estabilidade para 2015 de Portugal, 2015. Disponível em: < http:/ / ec.europa.eu/ europe2020/pdf/csr2015/csr2015_portugal_pt.pdf $>$. Acesso em: 20 jul. 2015. p. 7.

70 PARDAL, Paulo Alves. A contratação pública sob os ventos da austeridade orçamental. In: FERREIRA, Eduardo Paz; RODRIGUES, Nuno Cunha (Coord.). Novas fronteiras da contratação pública. Coleção Manuais académicos IDEFF. Coimbra: Coimbra, 2013. p. 177. 
No âmbito europeu, a Grécia e a Irlanda foram os primeiros países a recorrerem a auxílios externos, ainda em 2010. Em 2011 foi a vez de Portugal fazê-lo, vindo o auxílio por meio da chamada Troika - o Fundo Monetário Internacional, a Comissão Europeia e o Banco Central Europeu. O auxílio financeiro, contudo, era condicionado a ajustes na economia portuguesa, os quais foram definidos no Memorando de entendimento sobre as condicionalidades de politica econômica ${ }^{71}$, assinado em maio de 2011 e com duração de três anos ${ }^{72}$.

O Memorando é dividido em seções: política orçamental, sistema financeiro, empresas públicas, administração pública, saúde, mercado de trabalho, educação, energia, transportes, habitação e justiça. A contratação pública é um dos elementos constantes do Memorando, fazendo parte do Programa de Assistência Econômica e Financeira (PAEF). Especificamente, existem três áreas principais nas quais o Memorando incide sobre a contratação pública: as obrigações de informação, as obrigações de produção normativa e a concretização de um leque diversificado de medidas, cada uma subdividida em tópicos ${ }^{73}$.

As obrigações de informação são definidas como a "imperiosa necessidade de acompanhar de perto a evolução das contas públicas"; para tanto existiria a "obrigatoriedade do Estado português pôr em marcha diversos mecanismos aptos a facultar uma melhoria da informação". Nesse sentido a atenção, também, recaiu sobre as contratações públicas, de maneira a constar no Memorando, acerca deste tema, três ações específicas: "O reporte da execução orçamental, assim como sobre o acompanhamento dos riscos orçamentais derivados das PPP e das concessões. Além disso, avançava com o propósito de realizar um estudo detalhado sobre as PPP'74.

71 "O Memorando de Entendimento tocou todos os aspectos da vida do país. Por exemplo, entre as muitas medidas para o mercado laboral, estavam os cortes no subsídio de desemprego e a flexibilização dos critérios para despedimentos. [...] Foi também o memorando a determinar uma redução nas pensões". PÚBLICO. Memorando da Troika anotado, 2014. Disponível em: <http://www.publico. pt/economia/memorando-da-troika-anotado>. Acesso em: 21 jul. 2015.

72 PARDAL, Paulo Alves. A contratação pública sob os ventos da austeridade orçamental. In: FERREIRA, Eduardo Paz; RODRIGUES, Nuno Cunha (Coord.). Novas fronteiras da contratação pública. Coleção Manuais académicos IDEFF. Coimbra: Coimbra, 2013.

73 PARDAL, Paulo Alves. A contratação pública sob os ventos da austeridade orçamental. In: FERREIRA, Eduardo Paz; RODRIGUES, Nuno Cunha (Coord.). Novas fronteiras da contratação pública. Coleção Manuais académicos IDEFF. Coimbra: Coimbra, 2013. p. 177-178.

74 PARDAL, Paulo Alves. A contratação pública sob os ventos
O reporte da execução orçamental, primeira ação no âmbito das obrigações de informação, aparece nos itens 3 e 3.3 do Memorando ${ }^{75}$. Em resumo, este eixo de ações tinha por objetivo realizar levantamento acerca da situação orçamentária do Estado português de maneira a identificar as possíveis áreas em que ocorreriam cortes de gastos públicos. Por sua vez, a segunda ação no âmbito das obrigações de informação corresponde ao acompanbamento dos riscos orçamentais, especialmente a respeito do impacto que as PPP pudessem trazer ao orçamento do Estado. Este acompanhamento deveria ser realizado por meio de um relatório que integrasse o orçamento do Estado e também por outro relatório, anual e específico, sobre as PPP e as concessões ${ }^{76}$. Ambos os relatórios seriam realizados de acordo com o previsto, respectivamente, nos itens 3.11 e 3.21 do Memorando ${ }^{77}$.

da austeridade orçamental. In: FERREIRA, Eduardo Paz; RODRIGUES, Nuno Cunha (Coord.). Novas fronteiras da contrataşão pública. Coleção Manuais académicos IDEFF. Coimbra: Coimbra, 2013. p. 178.

75 “3. Medidas orçamentais estruturais. Objectivos: Melhorar a eficiência da administração pública pela eliminação de redundâncias, simplificando procedimentos e reorganizando serviços; regular a criação e o funcionamento de todas as entidades públicas (por exemplo, empresas, fundações, associações); melhorar o processo orçamental através do enquadramento legal recentemente aprovado, incluindo a adaptação em conformidade da Lei das Finanças Regionais e da Lei das Finanças Locais; reforçar a gestão de riscos, a responsabilização, o reporte e a monitorização. [...] 3.3. Melhorar o actual reporte mensal da execução orçamental, em base de caixa para as Administrações Públicas, incluindo em base consolidada $\mathrm{O}$ actual perímetro de reporte mensal inclui o Estado, Serviços e Fundos Autónomos, a Segurança Social, as administrações regional e local e será progressivamente ampliado para incluir o SEE e as PPP reclassificadas no âmbito das Administrações Públicas". PORTUGAL. Memorando de entendimento sobre as condicionalidades de politica económica, 2011. Disponível em: <http://www.contratacaopublica.com.pt/ xms/files/Documentacao/MoU_PT17maio2011.pdf>. Acesso em: 21 jul. 2015. p. 10-12.

76 PARDAL, Paulo Alves. A contratação pública sob os ventos da austeridade orçamental. In: FERREIRA, Eduardo Paz; RODRIGUES, Nuno Cunha (Coord.). Novas fronteiras da contratação pública. Coleção Manuais académicos IDEFF. Coimbra: Coimbra, 2013. p. 179 .

77 "3.11. Publicar um relatório abrangente sobre riscos orçamentais em cada ano como parte integrante do OE, começando com o OE para 2012. O relatório irá identificar os riscos orçamentais gerais e as responsabilidades contingentes, às quais o Estado possa estar exposto, incluindo todas as Parcerias Público-Privadas (PPP), SEE e garantias prestadas aos bancos. [...] 3.21. Melhorar o relatório anual sobre as PPP e as concessões preparado pelo Ministério das Finanças e da Administração Pública em Julho com uma avaliação abrangente dos riscos orçamentais derivados das PPP e das concessões. O relatório fornecerá informação e análise a nível sectorial. A revisão anual das PPP e concessões será acompanhada por uma análise dos fluxos de crédito canalizados para as PPP através dos bancos (empréstimos e títulos que não acções) por sector e uma 
Destaque é dado para o relatório sobre as PPP, que deveria ser subdividido em duas partes: análise dos riscos orçamentais (apuração do impacto das PPP em relação ao orçamento de Estado) e do fluxo de crédito (apuração do nível de endividamento das PPP com os bancos e com o setor financeiro) das $\mathrm{PPP}^{78}$.

Por fim, a terceira ação no âmbito das obrigações de informação - a realização de um estudo detalhado das PPP - é decorrente do item 3.19 do Memorando ${ }^{79}$. Entretanto, é importante destacar que tal análise já era vista como necessária pela Administração Pública, especialmente devido a auditorias realizadas pelo Tribunal de Contas que indicavam a necessidade do Estado "renegociar diversas PPP tendo em vista, nomeadamente, a redução das crescentes responsabilidades financeiras". Além disso, destaca-se que "havia ainda a necessidade de apurar as responsabilidades que o Estado pudesse ser chamado a honrar" $" 80$.

Percebe-se que as ações acima apresentadas têm relação direta com a necessidade vista pela Troika de tomar conhecimento acerca da situação financeiro-orçamental

avaliação do impacto na afectação de crédito e de efeitos crowding out. Este último aspecto será realizado em conjunto com o Banco de Portugal". PORTUGAL. Memorando de entendimento sobre as condicionalidades de política económica, 2011. Disponível em: < http://www. contratacaopublica.com.pt/xms/files/Documentacao/MoU_PT17maio2011.pdf $>$. Acesso em: 21 jul. 2015. p. 11-3, passim.

78 PARDAL, Paulo Alves. A contratação pública sob os ventos da austeridade orçamental. In: FERREIRA, Eduardo Paz; RODRIGUES, Nuno Cunha (Coord.). Novas fronteiras da contratação pública. Coleção Manuais académicos IDEFF. Coimbra: Coimbra, 2013. p. 180.

79 "3.19. Recrutar uma empresa de auditoria internacionalmente reconhecida para a realização de um estudo detalhado das PPP com acompanhamento do Instituto Nacional de Estatística (INE) e do Ministério das Finanças e da Administração Pública. O estudo identificará e, onde praticável, quantificará as responsabilidades contingentes de maior relevo e quaisquer montantes relacionados que possam vir a ser pagas pelo Estado. Avaliará a probabilidade de quaisquer pagamentos pelo Estado relativos a responsabilidades contingentes e quantificará os respectivos montantes. O estudo, a ser finalizado até ao final de Março de 2012, avaliará a viabilidade de renegociar qualquer PPP ou contrato de concessão, a fim de reduzir as responsabilidades financeiras do Estado. Todas as PPP e contratos de concessão estarão disponíveis para estas revisões". PORTUGAL. Memorando de entendimento sobre as condicionalidades de politica económica, 2011. Disponível em: <http://www.contratacaopublica. com.pt/xms/files/Documentacao/MoU_PT17maio2011.pdf $>$. Acesso em: 21 jul. 2015. p. 12.

80 PARDAL, Paulo Alves. A contratação pública sob os ventos da austeridade orçamental. In: FERREIRA, Eduardo Paz; RODRIGUES, Nuno Cunha (Coord.). Novas fronteiras da contratação pública. Coleção Manuais académicos IDEFF. Coimbra: Coimbra, 2013. p. 181. do Estado português. Dessa maneira, parece claro que o objetivo estabelecido era o de clarificar as áreas em que poderiam ser feitos cortes orçamentais, já que uma das preocupações se referia ao gasto estatal extremamente elevado - boa parte deste em PPP, o que significa gastos com contratos públicos.

A segunda grande ação prevista no Memorando (itens 3.13 e $3.20^{81}$ ) são as obrigações de produção normativa. Em outras palavras, o que se esperava com a realização desta ação é que o Estado português alterasse suas normas objetivando a monitoração dos investimentos bem como reforçasse as análises de risco prévias ao estabelecimento das PPP de maneira a se evitar aumento do gasto com contratos públicos - ao contrário, dever-se-ia reduzi-lo. A concretização de tais objetivos ficou por conta da aprovação da nova "lei das parcerias público-privadas" (Decreto-Lei no 111/2012, de 23 de maio), especificamente com a criação de uma Unidade Técnica de Acompanhamento de Projetos que ficaria responsável pela preparação, pelo desenvolvimento, pela execução e pelo acompanhamento global das $\mathrm{PPP}^{82}$.

Outra produção normativa se refere à Resolução do Conselho de Ministros $n^{\circ}$ 50/2012 - alterada pela Resolução do Conselho de Ministros ñ 66/2012. Por meio dessa Resolução, o governo português - cumprindo o previsto no item 5.18 do Memorando ${ }^{83}$ - se comprometeu a "con-

81 "3.13. Assegurar a implementação integral da nova Lei do Enquadramento Orçamental adoptando as necessárias alterações legais, incluindo à Lei das Finanças Regionais e à Lei das Finanças Locais: 1) o perímetro da Administração Pública abrangerá o Estado, Serviços e Fundos Autónomos, a Segurança Social, o SEE e as PPP reclassificadas no âmbito das Administrações Públicas e as administrações local e regional; 2) definir pormenorizadamente as características propostas para o enquadramento orçamental de médio prazo, incluindo a estratégia orçamental de médio prazo, processos de tomada de decisões e de definição de prioridades, regras de reporte, controlo de compromissos financeiros; e reservas de contingência apropriadas e respectivas regras de acesso. [...] 3.20. Pôr em prática um quadro legal e institucional reforçado, no âmbito do Ministério das Finanças e da Administração Pública, para a avaliação de riscos ex-ante da participação em PPP, concessões e outros investimentos públicos, bem como a monitorização da respectiva execução. O Tribunal de Contas terá de ser informado desta avaliação de riscos ex-ante. Poderá ser prestada assistência técnica, se necessário". PORTUGAL. Memorando de entendimento sobre as condicionalidades de política económica, 2011. Disponível em: <http://www. contratacaopublica.com.pt/xms/files/Documentacao/MoU_PT17maio2011.pdf >. Acesso em: 21 jul. 2015. p. 12-13.

82 GONÇALVES, Pedro Costa. Alterações ao código dos contratos públicos na sequência do "Memorando de Entendimento com a Troika". Revista de contratos públicos, Coimbra n. 5 maio/ago. 2012. p. 214.

83 " 5.18 . Garantir que as regras sobre designação de serviço uni- 
tratar a prestação do serviço universal de comunicações eletrónicas" de maneira a estabelecer regras acerca do tema que não fossem discriminatórias bem como a lançar novo concurso para que fossem designados novos fornecedores de serviço universal ${ }^{84}$.

Também, em relação à esfera das alterações legislativas, é de se destacar o item 7.19 e seguintes do Memorando, que trazem questões referentes à alteração das regras de concorrência. O item 7.19 traz que "o Governo eliminará as golden shares e todos os outros direitos estabelecidos por Lei ou nos estatutos de empresas cotadas em bolsa, que confiram direitos especiais ao Estado", enquanto o item 7.20 define que o governo deve "adoptar medidas para melhorar a celeridade e a eficácia da aplicação das regras da concorrência", dentre elas o estabelecimento de "um tribunal especializado no contexto das reformas do sistema judicial" e a propositura da revisão "da Lei da Concorrência, tornando-a o mais autónoma possível do Direito Administrativo e do Código do Processo Penal e mais harmonizada com o enquadramento legal da concorrência da UE", além de garantir que a autoridade competente pela concorrência tenha recursos suficientes e estáveis para seu funcionamento ${ }^{85}$.

Importante, também, destacar o que está previsto no tópico Contratações públicas do Memorando. Novamente, estabeleceu-se uma série de obrigações ao Estado português com o objetivo de garantia de transparência em um ambiente competitivo, além da melhoria dos gastos públicos ${ }^{86}$. Nesse contexto objetivou-se limitar a utilização do ajuste direto como mecanismo de con-

versal e o respectivo contrato de concessão do incumbente são não discriminatórias: renegociar o contrato de concessão com a empresa que actualmente fornece o serviço universal e lançar um novo concurso para designação de fornecedores de serviços universais". PORTUGAL. Memorando de entendimento sobre as condicionalidades de política económica, 2011. Disponível em: <http://www.contratacaopublica. com.pt/xms/files/Documentacao/MoU_PT17maio2011.pdf>. Acesso em: 21 jul. 2015. p. 27.

84 GONÇALVES, Pedro Costa. Alterações ao código dos contratos públicos na sequência do "Memorando de Entendimento com a Troika”. Revista de contratos públicos, Coimbra, n. 5 maio/ago. 2012. p. 214.

85 PORTUGAL. Memorando de entendimento sobre as condicionalidades de politica económica, 2011. Disponível em: <http://www. contratacaopublica.com.pt/xms/files/Documentacao/MoU_PT17maio2011.pdf>. Acesso em: 21 jul. 2015. p. 33-34.

86 PORTUGAL. Memorando de entendimento sobre as condicionalidades de politica económica, 2011. Disponível em: <http://www. contratacaopublica.com.pt/xms/files/Documentacao/MoU_PT17maio2011.pdf>. Acesso em: 21 jul. 2015. p. 34-35. tratação pública, procurou-se alterar determinados dispositivos do Código dos Contratos Públicos que continham omissões legislativas, e ainda, deram-se novos poderes ao Tribunal de Contas, especialmente no que concerne à sua prerrogativa de controle financeiro da contratação pública ${ }^{87}$.

Ainda no âmbito das alterações legislativas, é de se destacar, também, aquelas que visaram à alteração do regime de contratação pública das instituições de educação superior públicas existentes em forma de fundação, as quais se utilizavam de exceções à aplicação integral do regime de contratação pública. Também, alterou-se o regime de contratação de outras instituições - tais como os "hospitais constituídos sob a forma de entidade pública empresarial, as associações de direito privado que tenham como principal finalidade a ciência e a tecnologia e os laboratórios do Estado" -, entidades que perderam seus privilégios e passaram a estar completamente subjetivas ao regime regulamentado pelo $\mathrm{CCP}^{88}$.

Pelo exposto, percebe-se que o que se objetivava com tais alterações legislativas era o efetivo e rigoroso controle dos encargos e dos riscos, especialmente aqueles associados às PPP, que tiveram seu regime jurídico alterado pelo Decreto-Lei $n^{\circ} 111 / 2012$. Nessa mesma direção, veio o Decreto-Lei $n^{0}$ 149/2012, que sintetizou as demais alterações acima referidas ${ }^{89}$, todas elas com o

87 PARDAL, Paulo Alves. A contratação pública sob os ventos da austeridade orçamental. In: FERREIRA, Eduardo Paz; RODRIGUES, Nuno Cunha (Coord.). Novas fronteiras da contrataşão pública. Coleção Manuais académicos IDEFF. Coimbra: Coimbra, 2013. p. 183.

88 Além disto houve ainda "a introdução de modificações ao regime jurídico aplicável à preparação, lançamento, execução e alteração de parcerias público-privadas". A este respeito ver ESTORNINHO, Maria João. Curso de direito dos contratos públicos: por uma contratação pública sustentável. Coimbra: Almedina, 2014. p. 307-308.

89 As alterações realizadas pelo Decreto-Lei no 149/2012 no que concerne aos contratos públicos são as seguintes: a) Eliminação da exceção relativa às fundações do ensino superior; b) Eliminação de isenções à aplicação da parte II do CCP ("isenções especiais, permanentes ou temporárias, que permitam a adjudicação direta de contratos de montante inferior aos limites comunitários"); c) Eliminação de fundamento para ajuste direto; d) Alteração do regime de execução de trabalhos de suprimento de erros e omissões no âmbito da empreitada de obras públicas; e) Alteração do regime das obras e dos serviços complementares ao contrato inicial; e f) Eliminação do dever de elaboração de projetos de investigação e desenvolvimento. GONÇALVES, Pedro Costa. Alterações ao código dos contratos públicos na sequência do "Memorando de Entendimento com a Troika". Revista de contratos públicos, Coimbra, n. 5, maio/ago. 2012. p. 218-227. O autor chama a atenção, às págs. 227-238, que o legislador português "aproveitou a oportunidade" e reformou inúmeros 
objetivo de reduzir custos e aumentar o controle sobre os gastos do Estado português no âmbito dos contratos públicos.

Contudo, as alterações legislativas têm sido mais significativas no âmbito das finanças públicas e não no das contratações públicas. Por outras palavras, os resultados positivos, em termos de redução da despesa pública como consequência da implementação do PAEF, são decorrentes muito mais de produção normativa financeira do que na esfera do $\mathrm{CCP}^{90}$, o que pode significar que as alterações no quadro jurídico que regulamenta os contratos públicos não tenha sido assim tão eficaz quanto esperado.

Por último, o terceiro eixo de intervenção do Memorando no âmbito da contratação pública se refere a duas medidas específicas: impedir que ocorressem novas contratações em regime de PPP, por um lado, e renegociar os contratos das PPP existentes, por outro ${ }^{91}$. Tais medidas se apresentaram como fundamentais para a Troika por Portugal ser, conforme relatório de 2008 do próprio Tribunal de Contas, "o país europeu com maior percentagem de PPP quer em relação ao PIB, quer em relação ao OE [Orçamento de Estado]"'92.

\subsection{A contratação pública socioambiental em tempos de crise econômica}

Afirma-se que em Portugal houve euforia com o mecanismo da contratação pública, especialmente na década de 1990, em decorrência do grande interesse então

outros aspectos do CCP que não correspondiam a exigências do Memorando.

90 PARDAL, Paulo Alves. A contratação pública sob os ventos da austeridade orçamental. In: FERREIRA, Eduardo Paz; RODRIGUES, Nuno Cunha (Coord.). Novas fronteiras da contratação pública. Coleção Manuais académicos IDEFF. Coimbra: Coimbra, 2013. p. 201-202.

91 No Memorando a proibição de realização de novas PPP está prevista no item 3.17: "Evitar entrar em qualquer novo acordo de PPP antes de finalizar a revisão das PPP existentes e as reformas legais e institucionais propostas". Já a renegociação dos contratos existentes tendo em vista a redução de custos está prevista no item 3.19, citado acima. PORTUGAL. Memorando de entendimento sobre as condicionalidades de política económica, 2011. Disponível em: <http:// www.contratacaopublica.com.pt/xms/files/Documentacao/MoU_ PT17maio2011.pdf>. Acesso em: 21 jul. 2015. p. 12.

92 PARDAL, Paulo Alves. A contratação pública sob os ventos da austeridade orçamental. In: FERREIRA, Eduardo Paz; RODRIGUES, Nuno Cunha (Coord.). Novas fronteiras da contratação pública. Coleção Manuais académicos IDEFF. Coimbra: Coimbra, 2013. p. 183-184. demonstrado a respeito das parcerias público-privadas. Neste sentido as PPP adquiriram importante relevância no tema das contratações públicas, já que, a despeito das diferenças jurídicas entre a contratação tradicional, fundada no financiamento direto, e a contratação via PPP, ambas concorrem fortemente no que diz respeito ao aumento da despesa pública - ocasionado por constantes processos de renegociação e de reposição do equilíbrio financeiro ${ }^{93}$ - em proporção ao produto interno bruto de um Estado ${ }^{94}$.

Em uma situação de Estado-social provedor, este passa a oferecer bens e serviços coletivos à sociedade e, para tanto, recorre usualmente aos contratos públicos, os quais, logicamente, pressupõem gastos por parte do Estado. Contudo, e aqui entrando-se no âmbito do Estado português, os recursos não são infinitos, ainda mais durante o período em que Portugal se encontrava sob a égide do PAEF - isto sem considerar as próprias limitações de atuação do Estado decorrentes da integração europeia ${ }^{95}$.

93 PINHEIRO, André Modesto. Parcerias público-privadas, o papel do Estado: da densificação do conceito de comparador do sector público à problemática do reequilíbrio financeiro. 2012. f. Dissertação (Mestrado) - Universidade Católica Portuguesa, Lisboa, 2012. p. 36-37.

94 PARDAL, Paulo Alves. A contratação pública sob os ventos da austeridade orçamental. In: FERREIRA, Eduardo Paz; RODRIGUES, Nuno Cunha (Coord.). Novas fronteiras da contrataşão pública. Coleção Manuais académicos IDEFF. Coimbra: Coimbra, 2013. p. 171-172. Em consonância é importante destacar que Portugal foi um dos quatro únicos países da zona Euro cujo déficit veio a ultrapassar os 10\% do PIB, tanto em 2009 quanto em 2010. Além disso, chama a atenção também o fato de que havia uma trajetória de crescimento acelerado da dívida pública que faria com que em 2011 a mesma ultrapassasse os $100 \%$ do PIB. Ainda, destaca-se que Portugal "ao longo da década de 2000, teve um crescimento econômico muito lento - facto que, a continuar inalterado, não lhe permitiria gerar os recursos necessários para pagar a sua crescente dívida. Também os défices permanentes da balança de transações correntes, sempre à volta dos $10 \%$ do PIB anuais na referida década, haviam conduzido à existência de uma dívida externa consolidada superando os $100 \%$ do PIB. Também a dívida dos particulares, pessoas singulares ou empresas, se situava e situa em níveis elevadíssimos". A síntese se apresenta em um único sentido: "a trajetória insustentável das contas publicas parece ter sido o fator principal que levou a que Portugal, em conjunto com outros Estados, tivesse tido a necessidade de recorrer ao resgate internacional". A este respeito ver CAMPOS, Manuel Fontaine. A crise e a regulação internacional e europeia: o "Pacto Orçamental" como solução para a crónica indisciplina financeira do Portugal democrático? In: GONÇALVES, Pedro Costa. Concorrência e contratação pública: a integração de preocupações concorrenciais na contratação pública. In: ESTUDOS em homenagem a Miguel Galvão Teles. Coimbra: Almedina, 2012. v. 1. p. 81-94. p. 84-85, esp. nota. 11.

95 PARDAL, Paulo Alves. A contratação pública sob os ventos 
Mesmo no caso das PPP, ainda que seja a contraparte privada quem fique responsável por assegurar o financiamento do projeto a ser executado - o que faria com que os gastos do Estado não aumentassem, ao mesmo tempo em que os produtos e serviços continuariam sendo providos à população -, as coisas não saíram como planejado, já que os encargos pagos pela Administração pública aumentaram exponencialmente.

Deve-se aqui ser chamada a atenção para o problema central debatido neste texto: por um lado as contratações públicas, especialmente aquelas com incentivos socioambientais, são vistas como um dos principais mecanismos para que o Estado atinja seus objetivos como fornecedor de produtos e serviços à população ${ }^{96}$; por outro, a crise econômica de 2008, potencializada pelo PAEF, no caso de Portugal, trouxe a necessidade de máxima restrição dos gastos públicos, o que causa impacto nas contratações públicas sustentáveis por estas serem em geral mais custosas ${ }^{97}$ especialmente quando visam

da austeridade orçamental. In: FERREIRA, Eduardo Paz; RODRIGUES, Nuno Cunha (Coord.). Novas fronteiras da contratação pública. Coleção Manuais académicos IDEFF. Coimbra: Coimbra, 2013. p. 173.

96 Da mesma forma, quando se estima que em média cerca de $15 \%$ a $19 \%$ do Produto Interno Bruto da União Europeia seja decorrente das contratações públicas dos Estados-membros, percebe-se o peso que esta instituição tem no que concerne à possibilidade de direcionar a inovação e a busca por novas formas de proteção do meio ambiente e também dos fatores sociais que permeiam as sociedades. BASTOS, Filipe Brito. A escolba de critérios ambientais de adjudicação de contratos públicos: reflexões de Direito Administrativo nacional e europeu. Lisboa: ICJP, 2012. Disponível em: < http://www. icjp.pt/sites/default/files/papers/escolhacriteriosambientaisadjudicacaocp.pdf $>$. Acesso em: 21 jul. 2015. p. 5, nota 25; APPOLLONI, Andrea; D'AMATO, Alessio; CHENG, Wenjuan. Is public procurement going green? experiences and open issues. 2011. Available in: <http:/ ssrn.com/abstract=1970583 >. Access: 21 jul. 2015. p. 2; MATEI, Ani I.; MATEI, Lucica. Modernisation of the public procurement market. Towards a strategy of public marketing specific on the single market. Societal Innovations for Global Growth; Stream C: National Sustainable Development under Globalization Conditions, 2012. v. 1. Available at: <http://ssrn.com/abstract $=2135420>$. Accessed: 22 jul. 2015. p. 2; DRAGOS, Dacian C.; NEAMTU, Bogdana. Sustainable public procurement: life cycle costing (LCC) in the new EU Directive proposal. European Public Procurement and PPP Law Review, 2013. Available at: <http://ssrn.com/abstract $=2488021>$. Access: 22 jul. 2015. p. 29; ALENCASTRO, Maria Alice Cruz; SILVA, Edson Vicente da; LOPES, Ana Maria D’Ávila. Contratações sustentáveis na administração pública brasileira: a experiência do Poder Executivo federal. Revista de Administração Pública, Rio de Janeiro, v. 48, n. 1, jan./fev. 2014. Disponível em: <http://dx.doi.org/10.1590/S003476122014000100009>. Acesso em: 18 jul. 2015. p. 209.

97 Acerca dos custos mais elevados para a contratação pública ecológica, ver AMBEC, Stefan; LANOIE, Paul. Does it pay to be green? a systematic overview. Academy of Management. Perspectives, v. 22, n. 4, nov. 2008. Disponível em: < http://fdir.idei.fr/wp-content/ ao acréscimo de critérios de sustentabilidade socioambiental que ainda não estão em prática ${ }^{98}$. Assim, surge a questão: os contratos públicos com quesitos socioambientais são mais custosos para o Estado?

Em tempos do estabelecimento da ideia de que o meio ambiente precisa ser protegido e preservado, não apenas para as gerações atuais mas também para as futuras, parece, efetivamente, ser função do Estado levar adiante a proposta de proteção ambiental ${ }^{99}$. Além disso, vale destacar a expectativa do cidadão de que tal proteção deva ser feita por meio da manutenção dos níveis atuais de emprego, isto se não forem tais níveis mesmo aumentados. A preponderância do Estado parece ter, ainda, mais força quando se considera que esta instituição é efetivamente a única capaz de realizar a redistribuição dos bens públicos por meio de seus atos estatais $^{100}$, já que não se pressupõe que os cidadãos, voluntariamente, abram mão de desejos pessoais em prol da defesa do meio ambiente e/ou da manutenção do nível de emprego ${ }^{101}$.

uploads/2011/02/Does-it-Pay-to-be-Green.-A-Systematic-Overview.pdf $>$. Acesso em: 29 jul. 2015. Em seu estudo os autores buscam meios para tentar equilibrar os gastos iniciais com a contratação pública sustentável por parte das empresas privadas - gastos estes que são mais elevados do que a contratação pública tradicional com o ganho de competitividade e com a redução de custos, ambos em médio-longo prazo, sendo estes os elementos vistos pelos autores como passíveis de contrabalançar os elevados gastos iniciais. 98 ALENCASTRO, Maria Alice Cruz; SILVA, Edson Vicente da; LOPES, Ana Maria D'Ávila. Contratações sustentáveis na administração pública brasileira: a experiência do Poder Executivo federal. Revista de Administração Pública, Rio de Janeiro, v. 48, n. 1, jan./fev. 2014. Disponível em: <http://dx.doi.org/10.1590/S003476122014000100009>. Acesso em: 18 jul. 2015. p. 216.

99 BASTOS, Filipe Brito. A escolba de critérios ambientais de adjudicação de contratos públicos: reflexões de Direito Administrativo nacional e europeu. Lisboa: ICJP, 2012. Disponível em: <http://www.icjp. $\mathrm{pt} /$ sites/default/files/papers/escolhacriteriosambientaisadjudicacaocp.pdf $>$. Acesso em: 21 jul. 2015. p. 2.

100 Engloba-se na expressão atos estatais as ações dos poderes Executivo, Legislativo e Judiciário.

101 Tal afirmação é feita tendo-se por base a ideia de fragmentação política desenvolvida por Taylor. A fragmentação corresponde à situação social na qual os indivíduos acreditam que o poder político se encontra muito distante de si mesmos, sentindo-se frequentemente incapazes de "fazer a diferença" com base em uma atuação política que se restringe ao ato de votar. Desta maneira os indivíduos veem a si mesmos não como componentes de uma comunidade em que existem verdadeiros vínculos sociais entre si, isto é, como membros de uma unidade social coesa, mas apenas enxergam a si mesmos de maneira atomística, sem vínculos de simpatia com seus concidadãos e cada vez menos ligados aos demais em prol de projetos e de compromissos estabelecidos em comum. Nesta situação os indivíduos consideram como válidos apenas seus próprios objetivos de vida individual por acreditarem não haver possibilidade de se construir 
Por sua vez, é inegável que a atuação do Estado pressupõe gastos públicos. Nesse sentido a proteção do meio ambiente chama a atenção por ser aquela em que a presença estatal parece ser mais visível, especialmente em comparação com a manutenção do emprego (privado). A título de exemplo, espera-se que seja o Estado o responsável pela criação de incentivos - seja na forma de isenções fiscais, seja na forma da contratação pública - para o desenvolvimento de uma economia baseada em energias renováveis, especialmente quando se considera que a tecnologia para a implantação de tais energias é cara e não necessariamente atrativa a todos os empresários do setor - ainda que possa, em médio ou longo prazo, estimular a economia nacional como um todo ${ }^{102}$.

No entanto, se, por um lado, o Estado aparece como o principal incentivador de ações que visem à satisfação e à concretização do bem comum ${ }^{103}$, vale destacar, por outro, que os recursos estatais não são infinitos. Isto ficou claro, conforme exposto anteriormente, a partir da crise econômica de 2008, em que os Estados passaram a ter de restringir seus gastos públicos, pois, caso contrário, a situação seria ainda pior $^{104}$. É necessário, por-

política e juridicamente propostas que levem ao bem comum - entendendo-se o bem comum não como um ideal utopicamente estabelecido, mas sim como a definição de propostas políticas que, definidas por meio do consenso entre os envolvidos, possa efetivamente representar seus interesses. A este respeito ver TAYLOR, Charles. Argumentos filosóficos. São Paulo: Loyola, 2000. p. 294-299.

102 ANDRADE, Ana Rita Gomes de. As energias renováveis: uma luz verde aos auxílios do Estado? 2009. f. Monografia (Graduação) - Pós-Graduação em Direito da Energia, Instituto de Ciências Jurídico-Políticas da Faculdade de Direito, Universidade de Lisboa, Lisboa, 2009. Disponível em <http://www.icjp.pt/sites/default/ files/media/643-961.pdf>. Acesso em: 21 jul. 2015. p. 4.

103 BASTOS, Filipe Brito. A escolha de critérios ambientais de adjudicação de contratos públicos: reflexões de Direito Administrativo nacional e europeu. Lisboa: ICJP, 2012. Disponível em: <http://www.icjp. $\mathrm{pt} /$ sites/default/files/papers/escolhacriteriosambientaisadjudicacaocp.pdf $>$. Acesso em: 21 jul. 2015. p. 2.

104 Uma das ideias referentes à limitação dos gastos públicos seria a sua constitucionalização, isto é, a inclusão, nos textos constitucionais, de limites explícitos a tais gastos, de maneira que se pudesse sancionar o administrador público caso este não cumprisse o limite estabelecido ou até mesmo caso viesse a propor algo que ultrapassasse tal limite. Este foi o caminho escolhido pela Alemanha, "que introduziu em 2009 na Grundgesetz (GG) um limite para o défice orçamental, para valer a partir de 2016". Nabais discorda desta proposta por considerá-la ineficaz, já que passou-se a justificar os gastos atuais que também seriam onerosos às gerações futuras - com base no argumento de que os ativos por eles produzidos seriam duradouros ou seja, gasta-se muito hoje para ter-se o usufruto no futuro, quando então pagar-se-iam os débitos. A este respeito ver NABAIS, José Casalta. Da sustentabilidade do Estado fiscal. In: NABAIS, José Casalta; SILVA, Suzana Tavares da (Coord.). Sustentabilidade fiscal em tempos de crise. Coimbra: Almedina, 2011. p. 31-3. Acerca da proposta alemã de tanto, verificar - inicialmente em termos teóricos - se a contratação pública sustentável é efetiva e eficaz, ou seja, se ela contribui para o equilíbrio entre, de um lado, a proteção do meio ambiente e dos fatores sociais e, de outro, o equilíbrio fiscal do próprio Estado.

Nesse sentido, parece haver dúvidas na doutrina sobre a efetividade das contratações públicas "verdes" em termos de eficiência e eficácia - especialmente quando se leva em consideração a componente "menores custos" - em comparação com outros mecanismos tradicionais de estímulo ambiental, tais como licenças de poluição e tributação ambiental. O primeiro dos argumentos em questão diz respeito à ideia de que as contratações públicas sustentáveis são na prática mais caras do que a contratação pública "normal", ou seja, mais dispendiosas de recursos públicos do que aquelas contratações que não levam em consideração critérios ambientais e sociais. Dessa maneira, o maior gasto público em um momento histórico de necessidade de diminuição deste mesmo gasto público geraria questionamentos acerca da eficácia e da eficiência deste modelo de contratação pública ${ }^{105}$.

limitação constitucional dos gastos públicos - bem como de outras propostas com o mesmo objetivo - ver também CAMPOS, Manuel Fontaine. A crise e a regulação internacional e europeia: o "Pacto Orçamental" como solução para a crónica indisciplina financeira do Portugal democrático? In: GONÇALVES, Pedro; GOMES, Carla Amado; MELO, Helena; CALVÃO, Filipa (Coords.). A crise e o direito público. Lisboa: ICJP, 2013. p. 81-94. Disponível em: < http://www. icjp.pt/publicacoes/1/4290>. Acesso em: 21 jul. 2015. p. 87-9.

$105 \mathrm{O}$ aumento dos gastos se daria, dentre outros fatores, pela própria necessidade que um Estado-membro tem de estudar e conhecer os próprios aspectos legais que regulamentam a contratação pública sustentável, já que “a complexidade ainda permanece [mesmo] após o estabelecimento das compras públicas sustentáveis nas diretivas, já que os deveres de definição precisa e de verificação [do significado de seus termos] ainda sobrecarregam os Estadosmembros. A formulação de requisitos e critérios de acordo com a legislação e com os princípios da Comunidade é um esforço tecnicamente desafiador e exige muita perícia [jurídica]". ERIKSSON, Emelie. Green public procurement as a policy instrument. Study from a law and economics perspective on the efficiency of using green public procurement to achieve sustainable development in the EU. 2014. 77 f. Dissertação (Mestrado) - Lund University, Suécia, 2014. Available at: <http://lup.lub.lu.se/luur/download?func $=$ downloadFile\& recordOId=4451209\&fileOId=4465017>. Accessed: 20 jul. 2015. p. 47-48. A autora também afirma que os custos legais são elevados porque os Estados-membros podem sofrer punições caso não sigam o que está estabelecido nas diretivas, inclusive caso as empresas privadas vencedoras do concurso também não sigam os critérios ambientais definidos. Desta maneira, se não pelo próprio custo eventualmente mais elevado do produto "socioambientalmente amigável", "os custos são, assim, criados em parte para garantir que determinada política ambiental está em conformidade com o quadro jurídico pertinente, em parte para verificar se as ambições políti- 
Outra crítica se fundamenta na ideia de que a entidade adjudicante não tem conhecimento generalizado a respeito de quem pode fazer o que, ou seja, não conhece a capacidade de todas as possíveis empresas privadas existentes no mercado, de maneira que o resultado final não seja necessariamente aquele que atinja o equilíbrio entre a maior proteção ambiental e o menor gasto total - sendo este o somatório tanto do gasto da Administração Pública quanto do gasto das empresas privadas ${ }^{106}$.

Da mesma maneira, as contratações públicas "verdes" não parecem ser tão eficientes em termos de redução do impacto ambiental geral, já que os procedimentos de adjudicação atuam apenas de maneira indireta em relação a tal objetivo ${ }^{107}$. Por outras palavras, significa dizer que os cadernos de encargos definem um conjunto padrão de critérios ambientais a serem atingi-

cas da política pública também são atingidos". No mesmo sentido: "este é um tema [contratação pública com critérios socioambientais] a que as instituições europeias e nacionais não tinham (pelo menos até às diretivas de 2004) sido muito sensíveis, melhor dizendo, era uma questão em que não se sentiam muito confortáveis. A razão é simples: as instituições europeias receavam que, ao incluir nas regras de adjudicação dos contratos públicos critérios não estritamente económicos, se diminuísse a transparência dos mercados e potenciasse a discriminação dos concorrentes em função da nacionalidade". PEREIRA, Pedro Matias; FRANCO, João Soares. A adjudicação de contratos públicos em contexto de crise. Revista de contratos públicos, Coimbra, n. 5, maio/ago. 2012. p. 154.

106 A este respeito apontam-se duas situações específicas. A primeira delas pode ser explicada da seguinte maneira. Suponha-se que a entidade adjudicante estabeleça como critério a necessidade de redução em $10 \%$ de um gasto ambiental qualquer e que determinada empresa $\mathrm{X}$ possa reduzir em até $15 \%$, mas omite tal informação e apresenta em sua proposta a possibilidade de redução em $12 \%$. Neste exemplo hipotético se esta empresa $\mathrm{X}$ viesse a ganhar o concurso estaria obrigada a reduzir em $12 \%$, que foi sua proposta original, em vez dos $15 \%$ que é efetivamente capaz de fazer, o que significa, de certa maneira, uma perda para o Estado. A segunda situação refere-se ao fato de que os contratos públicos sustentáveis obrigam apenas às partes contratantes, mas não aquelas empresas que não tomem parte do processo. Por outras palavras, a proteção ambiental decorrente das ações da empresa vencedora do concurso pode ser anulada pelo fato de que as demais empresas não são obrigadas a realizar tal proteção. Por sua vez, a implantação de outros mecanismos econômicos, tal como tributação ambiental, solucionaria estes dois problemas, já que aplicar-se-ia a todas as empresas, por um lado, e por outro exigiria destas o cumprimento do máximo possível conforme estabelecido em lei. A este respeito ver LUNDBERG, Sofia; MARKLUND, Per-Olov; BRÄNNLUND, Runar. Assessment of green public procurement as a policy tool: cost-efficiency and competition considerations. 2009. Available at: <http://ssrn.com/ abstract $=1831089>$. Accessed: 22 jul. 2015. p. 7-8.

107 APPOLLONI, Andrea; D'AMATO, Alessio; CHENG, Wenjuan. Is public procurement going green? experiences and open issues, 2011. Available at: <http://ssrn.com/abstract $=1970583>$. Accessed: 21 jul. 2015. p. 7. dos e que devem ser cumpridos por todas as empresas interessadas. Contudo, como estas possuem diferentes tecnologias para a produção dos produtos que lhes são requisitados, a relação custo-benefício final pode ser desvantajosa, já que algumas empresas poderiam gastar mais - inclusive em termos ambientais - para satisfazer os critérios do concurso, de maneira que o resultado final seja ineficiente ${ }^{108}$.

Por outro lado, a ineficiência das contratações públicas "verdes" pode ser reduzida se o processo de adjudicação exigir menores custos marginais de proteção ambiental, o que permitiria certa igualdade entre as empresas participantes ${ }^{109}$ - especialmente quando se considera, ao menos no âmbito do espaço europeu, que as contratações públicas "verdes" não têm fronteiras, ou seja, são abertas a empresas privadas de todos os países que compõem a União Europeia ${ }^{110}$.

A efetividade das contratações públicas sustentáveis depende da satisfação de duas condições: 1) O processo de adjudicação deve ser o mais claro possível no sentido de comprovar que os benefícios globais (em termos de sociedade e não apenas para o Estado) decorrentes da proteção ambiental suplantam os custos da implantação das exigências ambientais; 2) Os objetivos ambientais devem ser atingidos com o menor custo global possível $^{111}$. Além disso, uma vez que as contratações públicas são estabelecidas de maneira descentralizada ${ }^{112}$, torna-se

108 LUNDBERG, Sofia; MARKLUND, Per-Olov; BRÄNNLUND, Runar. Assessment of green public procurement as a policy tool: cost-efficiency and competition considerations, 2009. Available at: $<$ http://ssrn.com/abstract=1831089 $>$. Accessed: 22 jul. 2015. p. 17.

109 APPOLLONI, Andrea; D'AMATO, Alessio; CHENG, Wenjuan. Is public procurement going green? experiences and open issues, 2011. Available at: <http://ssrn.com/abstract $=1970583>$. Accessed: 21 jul. 2015. p. 6-7.

110 LUNDBERG, Sofia; MARKLUND, Per-Olov; BRÄNNLUND, Runar. Assessment of green public procurement as a policy tool: cost-efficiency and competition considerations, 2009. Available at: $<$ http://ssrn.com/abstract=1831089>. Accessed: 22 jul. 2015. p. 18.

111 LUNDBERG, Sofia; MARKLUND, Per-Olov; BRÄNNLUND, Runar. Assessment of green public procurement as a policy tool: cost-efficiency and competition considerations, 2009. Available at: <http://ssrn.com/abstract=1831089>. Accessed: 22 jul. 2015. p. 8. Os autores afirmam, contudo, que a primeira condição é quase impossível de ser concretizada, já que "é irrealista presumir que a Administração Pública terá informação perfeita". Consequentemente, na prática, "a partir da perspectiva do bem-estar social é quase impossível estabelecer objetivos ambientais ótimos. Em vez destes, estabelecem-se objetivos ambientais desejados, e a condição da relação custo-benefício acaba por ser a guia para se atingir tais objetivos". 112 Tal descentralização se refere ao fato de que é possível a re- 
possível adequá-las a situações específicas, localizadas, de maneira que os benefícios sejam resultantes não necessariamente de uma grande contratação pública "global" mas sim do somatório do resultado de pequenas contratações públicas "locais".

Assim, ainda que a União Europeia possua extenso guia acerca de ações que podem ser realizadas pelos Estados no âmbito da contratação pública sustentável ${ }^{113} \mathrm{e}$ venha a incentivar este tipo de adjudicação, de maneira geral a contratação pública sustentável se torna vantajosa apenas em áreas nas quais ainda não haja uma política ambiental padronizada e/ou em novas áreas de desenvolvimento tecnológico, tais como na reciclagem e nas energias renováveis. Por outro lado, naqueles setores em que a intervenção pública já se encontra estabelecida a contratação pública sustentável não é vantajosa, especialmente tendo-se em conta o fato de que seria necessário reestruturar por completo a atuação estatal de maneira a inserir critérios verdes, o que em última instância

alização de contratação em diferentes níveis administrativos - nomeadamente o local e o nacional - enquanto um tributo tem caráter centralizado, ou seja, nacional (ao menos em Estados unitários como é o caso de Portugal). LUNDBERG, Sofia; MARKLUND, Per-Olov; BRÄNNLUND, Runar. Assessment of green public procurement as a policy tool: cost-efficiency and competition considerations, 2009. Available at: <http://ssrn.com/abstract $=1831089>$. Accessed: 22 jul. 2015. p. 17.

113 As recomendações estão disponíveis em: < http://ec.europa. $\mathrm{eu} /$ environment/gpp/index_en.htm $>$. Acerca de tais recomendações são feitas inúmeras críticas, especialmente ao fato de que estas visariam à transformação das questões ambientais - que do ponto de vista jurídico podem ser apresentadas como direitos sociais ou ainda direitos de terceira dimensão - em mero mecanismo para a satisfação de demandas econômicas, ou seja, o meio ambiente passaria a ser mais um serviço a ser oferecido pelo mercado aos cidadãos e não um direito a ser garantido e protegido pelo Estado em benefício destes, especialmente quando se considera que tais recomendações são dirigidas primariamente para os atores econômicos e não para a sociedade civil. A este respeito ver FRAGA, Fernando Losada. The Green Paper on the modernization of public procurement policy of the EU: towards a socially-concerned market or towards a marketoriented society? Oñati Socio-Legal Series, v. 2, n. 4, 2012. Available at: <http://ssrn.com/abstract=2009257>. Accessed: 22 jul. 2015. No mesmo sentido mercadológico das considerações socioambientais, inclusive com a afirmação de que "as políticas [propostas pela União Europeia], entretanto, parecem favorecer o termo 'crescimento sustentável' em vez de desenvolvimento sustentável, o que pode significar que o objetivo do crescimento econômico tenha precedência ao objetivo da proteção ambiental" ver também ERIKSSON, Emelie. Green public procurement as a policy instrument. Study from a law and economics perspective on the efficiency of using green public procurement to achieve sustainable development in the EU. 2014. $77 \mathrm{f}$. Dissertação (Mestrado) - Lund University, Suécia, 2014. Available at: <http://lup.lub.lu.se/luur/download?func $=$ downloadFile\&reco rdOId $=4451209 \&$ fileOId $=4465017>$. Accessed: 20 jul. 2015. p. 32 . geraria mais gastos em vez de maior economia ${ }^{114}$.

Outro ponto de grande relevância no âmbito dos contratos públicos sustentáveis - especialmente em tempos de restrições orçamentárias - diz respeito ao fato de que estes são, inicialmente, mais dispendiosos, especialmente se se utilizar como critério de adjudicação a análise do custo do ciclo de vida, especialmente em relação aos Estados-membros menos industrializados. Nessa perspectiva, o que se verifica é que, inicialmente, tais Estados-membros precisariam importar as tecnologias "verdes" ou pagar, por meio dos contratos públicos, um valor mais elevado para estimular as empresas nacionais a participarem de contratos públicos com critérios socioambientais, o que entra em contradição com o momento economicamente restritivo da atualidade $^{115}$. Além disso, a própria definição de qual seria o preço razoável a pagar por um produto quando se considera seu ciclo de vida implica em gastos, tanto financeiros quanto técnicos, o que pode ser visto como uma forma de desincentivo a tais tipos de contrato ${ }^{116}$.

114 APPOLLONI, Andrea; D'AMATO, Alessio; CHENG, Wenjuan. Is public procurement going green? experiences and open issues, 2011. Available at: <http://ssrn.com/abstract $=1970583>$. Accessed: 21 jul. 2015. p. 7-8. A respeito dos pontos positivos dos contratos públicos sustentáveis, os autores trazem em seu texto um estudo a respeito dos sete países "verdes" da União Europeia (Alemanha, Áustria, Dinamarca, Finlândia, Holanda, Reino Unido e Suécia). O estudo mostra que os contratos públicos sustentáveis correspondem, na média dos sete países, a $45 \%$ do valor total dos contratos públicos e a 55\% do número total de contratos em 2006/7 - após, portanto, o surgimento das diretivas de 2004. O estudo também comprova que os contratos públicos sustentáveis trouxeram ganhos a tais países, nomeadamente no que se refere à redução da emissão de gás carbônico (CO2) - redução esta que na média ficou em $25 \%$ - bem como na redução do próprio custo médio deste tipo de contrato, que em média são $1,24 \%$ mais baratos que os contratos públicos não "verdes". O estudo sugere que os setores dos transportes, da construção e da eletricidade são aqueles em que há maior possibilidade de redução de impacto ambiental por cada euro gasto, desde que isto se vincule a novos projetos nestes setores e não à reestruturação do que já existe para atingir padrões ambientais.

115 Tal questionamento se torna ainda mais relevante quando se considera que as contratações públicas que têm como critério a análise do custo de vida pressupõem contratos de médio-longo prazo, o que pode trazer problemas futuros em termos de orçamento - ainda que se espere que, em longo prazo, os custos venham a diminuir. DRAGOS, Dacian C.; NEAMTU, Bogdana. Sustainable public procurement in the EU: experiences and prospects. In: LICHERE, Francois; CARANTA, Roberto; TREUMER, Steen (Eds.). Novelties in the 2014 Directive on public procurement. DJØF Publishing, 2014. Available at: <http://ssrn.com/abstract $=2488047>$. Accessed: 22 jul. 2015. p. 23-24.

116 ERIKSSON, Emelie. Green public procurement as a policy instrument. Study from a law and economics perspective on the efficiency of using green public procurement to achieve sustainable develop- 
Por sua vez, a utilização de contratos públicos sustentáveis, também, é relevante quando tecnologias "verdes" já estão disponíveis no mercado mas não são comumente utilizadas pelas empresas privadas. Neste sentido, e em comparação, por exemplo, com a implantação de eventual "tributo verde" 117 , as contratações públicas sustentáveis exercem verdadeiro papel acelerador no processo de mudança tecnológica, já que o resultado da tributação aparece em médio-longo prazo - e, enquanto não produzem efeitos, o meio ambiente continua a ser degradado. Nesse sentido, como as contratações públicas têm prazo menor no que diz respeito aos seus resultados, elas se tornam vantajosas por permitirem proteção ambiental quase imediata $^{118}$ - por exemplo, por obrigar as empresas interessadas em participar da contratação pública a renovar seu parque industrial com novos métodos "verdes".

Em síntese, pode-se afirmar que são quatro os fatores definidores da implantação (ou não) de um processo de contratação pública sustentável: 1) A relação custo $x$ benefício da implantação desta política; 2) A familiaridade dos atores envolvidos (públicos e privados) com a contratação pública sustentável - ou seja, tais atores precisam conhecer o conceito e os objetivos deste tipo de contratação; 3) A existência, ou seja, a disponibilidade, de bens e serviços que possam ser adquiridos com base em critérios de sustentabilidade socioambiental; e 4) A existência de incentivos e de pressões institucionais públicas e privadas - pela implementação da contratação pública sustentável ${ }^{119}$.

ment in the EU. 2014. 77 f. Dissertação (Mestrado) - Lund University, Suécia, 2014. Available at: <http://lup.lub.lu.se/luur/downloa $\mathrm{d}$ ? func $=$ downloadFile\&recordOId $=4451209 \&$ fileOId $=4465017>$. Accessed: 20 jul. 2015. p. 61.

117 A respeito dos mecanismos fiscais - os tributos ambientais e os benefícios fiscais ambientais - que podem contribuir com a sustentabilidade, nomeadamente a ambiental, ver NABAIS, José Casalta. Da sustentabilidade do Estado fiscal. In: NABAIS, José Casalta; SILVA, Suzana Tavares da (Coord.). Sustentabilidade fiscal em tempos de crise. Coimbra: Almedina, 2011. p. 44-54.

118 LUNDBERG, Sofia; MARKLUND, Per-Olov; BRÄNNLUND, Runar. Assessment of green public procurement as a policy tool: cost-efficiency and competition considerations, 2009. Available at: $<$ http://ssrn.com/abstract=1831089>. Accessed: 22 jul. 2015. p. 12. Os autores destacam ainda, em defesa das contratações públicas "verdes", o impacto político negativo que a criação de eventual novo tributo causaria junto à sociedade. Por outro lado, argumentam que o mecanismo econômico da tributação pode trazer resultados mais duradouros, já que a presença constante do tributo ao longo do tempo faria com que as empresas renovassem seu parque industrial de maneira permanente em comparação com a possível renovação apenas temporária que uma empresa poderia fazer com o objetivo único de participar de um concurso público específico.

119 ALENCASTRO, Maria Alice Cruz; SILVA, Edson Vicente
Dessa maneira, a despeito das críticas, parece não haver dúvidas que os contratos públicos sustentáveis tanto do ponto de vista ambiental quanto social - fazem parte na atualidade da cultura administrativa dos Estados-membros da União Europeia, ainda que a ênfase tenha sido maior nos critérios ambientais e não nos critérios sociais ${ }^{120}$. Nesse sentido, estudos mostram, em síntese, que as considerações ambientais encontram-se com frequência nas especificações técnicas dos contratos, enquanto as considerações sociais são apresentadas como exigências de desempenho dos contratos públi$\cos ^{121}$.

\section{A realidade da contratação pública em TEMPOS DE CRISE}

A crise econômica de 2008 pode ser analisada de um ponto de vista positivo se se considerar que a mesma abriu a possibilidade de criação de estímulos às políticas sustentáveis, inclusive como resposta à própria crise econômica. Por outras palavras, acreditava-se naquele momento que as propostas "verdes" poderiam servir para auxiliar na recuperação econômica dos países que as adotassem ao mesmo tempo em que se implantava uma suposta base de sustentação para a economia qual seja, a da "economia verde". Contudo, o que se viu foi a diminuição do entusiasmo inicial a respeito de tal

da; LOPES, Ana Maria D’Ávila. Contratações sustentáveis na administração pública brasileira: a experiência do Poder Executivo federal. Revista de Administração Pública, Rio de Janeiro, v. 48, n. 1, jan./ fev. 2014. p. 216-217.

120 DRAGOS, Dacian C.; NEAMTU, Bogdana. Sustainable public procurement in the EU: experiences and prospects. In: LICHERE, Francois; CARANTA, Roberto; TREUMER, Steen (Eds.). Novelties in the 2014 Directive on public procurement. DJØF Publishing, 2014. Available at: <http://ssrn.com/abstract=2488047>. Accessed: 22 jul. 2015. p. 22.

121 Tais estudos são sintetizados por DRAGOS, Dacian C.; NEAMTU, Bogdana. Sustainable public procurement in the EU: experiences and prospects. In: LICHERE, Francois; CARANTA, Roberto; TREUMER, Steen (Eds.). Novelties in the 2014 Directive on public procurement. DJØF Publishing, 2014. Available at: <http://ssrn. com/abstract $=2488047>$. Accessed: 22 jul. 2015. p. 8-9. A título de exemplo, à pág. 12 os autores dão mais detalhes acerca do uso dos critérios socioambientais nos contratos: informam os autores que em $66 \%$ dos contratos as considerações socioambientais estão presentes nas especificações técnicas (art. $42^{\circ}$ da diretiva 2014/24/UE); já em $45 \%$ deles tais considerações são apresentadas como critério decisivo de adjudicação (art. $67^{\circ}$ da diretiva 2014/24/UE) e em 29\% aparecem como um critério de seleção qualitativa (art. $57^{\circ}$ da diretiva 2014/24/UE) para o estabelecimento do contrato. 
proposta e o surgimento de um clima mais pessimista em relação a tais políticas sustentáveis, especialmente a partir de 2010, já que a persistência da crise econômica parece ter feito com que a preocupação dos governos se voltasse para a recuperação da economia por meio de programas de austeridade econômica em detrimento do estímulo a inovações socioambientais ${ }^{122}$.

No caso português, as principais propostas de políticas "verdes" apareceram na Estratégia Nacional para as Compras Públicas Ecológicas, conforme divulgado pela Comissão Europeia, com o documento trazendo os objetivos a serem atingidos pelo Estado português no que concerne a tais políticas. Nesse sentido estabeleceu-se em tal documento que pelo menos $50 \%$ dos contratos públicos feitos pelo Estado português deveriam incluir critérios ambientais a serem considerados durante o processo de adjudicação. Além disso, estabeleceram-se áreas prioritárias para os contratos públicos sustentáveis, quais sejam: construção, transportes, energia, aquisição de equipamentos de escritório (incluindo papel, produtos de limpeza e serviços de manutenção de edifícios públicos) e aquisição de equipamentos de informática $^{123}$.

Uma vez estabelecidos tais objetivos, resta verificar como o Estado português agiu em relação aos contratos públicos sustentáveis, ou seja, se efetivamente concretizaram-se as propostas previamente apresentadas. Uma das formas de se analisar os contratos públicos é por meio do Portal BASE, um site administrado pelo Instituto da Construção e do Imobiliário (InCI) que traz "a informação sobre todos os contratos celebrados ao abrigo do Código dos Contratos Públicos" em Portugal. O próprio órgão disponibiliza relatórios anuais (referentes ao ano de 2010 a 2013) a respeito da contratação pública, os quais têm por objetivo permitir que o cidadão tenha subsídios para exercer seu papel de fiscalizador do Estado por meio da aplicação do princípio da trans-

122 GEELS, Frank W. The impact of the financial-economic crisis on sustainability transitions: financial investment, governance and public discourse. Working paper n. 39. Welfare, wealth and work for Europe. 2013. Available at: <http://www.foreurope.eu/fileadmin/ documents/pdf/Workingpapers/WWWforEurope_WPS_no039_ MS205.pdf>. Accessed: 22 jul. 2015. p. 6. A título de exemplo o autor mostra, à pág. 15, que o investimento estatal geral como porcentagem do PIB no Reino Unido e nos Estados Unidos estava a aumentar entre 1999 e 2008, vindo a seguir a cair drasticamente até 2011.

123 COMISSÃO EUROPEIA. Environment. GPP National Action Plans. National GPP Action Plans (policies and guidelines). Available at: <http://ec.europa.eu/environment/gpp/action_plan_en.htm>. Accessed: 22 jul. 2015. p. 13 parência a respeito do gasto público ${ }^{124}$.

Considerando-se os relatórios disponíveis no Portal $B A S E$, optou-se nesta pesquisa pela análise comparativa daqueles referentes aos anos de 2010 e 2013. Essa escolha foi feita tendo-se em vista o fato de ser o primeiro relatório disponível referente ao ano de 2010, o que faz com que a análise dos gastos públicos em tal ano seja interessante quando se considera que este foi o último ano em que Portugal não estava sob influência direta da Troika. Por sua vez, o último relatório disponível no Portal BASE refere-se ao ano de 2013, o que também se apresenta como relevante quando se considera que neste ano algumas alterações legislativas exigidas pelo Memorando de Entendimento já haviam sido realizadas pelo Estado português, o que causou impacto direto nas contratações públicas.

\subsection{Os contratos públicos em 2010}

No que diz respeito ao ano de 2010, o relatório informa que foram realizados 79.739 concursos públicos por meio de plataformas eletrônicas ou por ajuste direto. Tais procedimentos são divididos em contratos de aquisição de bens e serviços (66.465) e em contratos de empreitadas de obras públicas (13.274), totalizando aproximadamente 11 mil milhões de euros. Apesar de haver mais contratos no âmbito dos bens e serviços o valor total destes é menor, correspondendo a pouco mais de 4 mil milhões de euros - o que equivale a $39 \%$ do montante total -, com os contratos de obras públicas correspondem a $61 \%$ do montante total dos contratos públicos ${ }^{125}$.

Em relação ao valor acima apresentado, tem-se que $65 \%$ deste corresponde a procedimentos concursais típicos (concursos públicos, concursos limitados por prévia qualificação, procedimentos de negociação e diálogo concorrencial). O valor total dos procedimentos concursais ficou pouco acima dos 7 mil milhões de euros. Destes 5,2 mil milhões, 74\% correspondem a contratos de empreitadas de obras públicas. Importa ainda destacar que "a maioria (77\%) são concursos internacionais

124 PORTUGAL. Portal BASE. O portal BASE. Disponível em: <http://www.base.gov.pt/Base/pt/OPortal/Base>. Acesso em: 23 jul. 2015.

125 PORTUGAL. Portal BASE. Contratação pública em Portugal: relatório síntese 2010, 2011. Disponível em: <http:/ /www.base.gov. pt/mediaRep/inci/files/base_docs/Rel_Contr_Publ_2010.pdf $>$. Acesso em: 23 jul. 2015. p. 4. 
(isto é, procedimentos concursais de valor superior aos limiares comunitários), no montante total de 5,5 mil milhões de euros", em que as obras públicas corresponderam a $71 \%$ dos gastos. Os demais $23 \%$ correspondem a concursos nacionais ${ }^{126}$.

Os demais 35\% dos gastos totais correspondem aos ajustes diretos. Nesse caso tem-se que $62 \%$ do valor está vinculado aos contratos referentes a bens e serviços e o restante (38\%) sendo referente a contratos de empreitadas de obras públicas. Chama a atenção o fato de que em apenas $42 \%$ das propostas de ajuste direto realizadas por meio de plataformas eletrônicas foram efetuadas consultas a mais de uma entidade. 52\% dos ajustes diretos foram realizados pelas plataformas eletrônicas ${ }^{127}$.

Como se pode perceber pelo exposto, o relatório acerca do ano de 2010 é muito simples, limitando-se a classificar os contratos públicos tendo-se por base o tipo de contrato (bens e serviços ou obras públicas) e o percentual gasto em cada tipo, além de identificá-los como sendo nacionais ou internacionais. Não há no relatório de 2010 nenhuma referência explícita a critérios socioambientais que possam ter sido, eventualmente, utilizados durante o processo de adjudicação dos contratos $^{128}$.

\subsection{Os contratos públicos em 2013}

No ano de 2013, o número de procedimentos registrados no Portal BASE aumentou em comparação

126 PORTUGAL. Portal BASE. Contratação pública em Portugal: relatório síntese 2010, 2011. Disponível em: <http://www.base.gov. pt/mediaRep/inci/files/base_docs/Rel_Contr_Publ_2010.pdf $>$. Acesso em: 23 jul. 2015. p. 5-6.

127 PORTUGAL. Portal BASE. Contratação pública em Portugal: relatório síntese 2010, 2011. Disponível em: <http://www.base.gov. pt/mediaRep/inci/files/base_docs/Rel_Contr_Publ_2010.pdf $>$. Acesso em: 23 jul. 2015. p. 6-7.

128 É interessante chamar a atenção a este fato - ausência de critérios socioambientais no relatório dos contratos públicos em 2010 - já que o CCP, desde 2008, permitia a inserção de critérios socioambientais nos contratos públicos, conforme apresentado no item 1.2 deste texto (supra). Sendo assim, seria de se questionar o que teria levado a Administração Pública portuguesa a não inclúi-los em seus cadernos de encargos naquele momento. A resposta a tal questionamento está fora do escopo deste texto, mas talvez uma pista para investigação futura esteja no fato de que a Administração Pública portuguesa talvez não tivesse muita preocupação em incentivar tais mecanismos ao mesmo tempo em que não tinha preocupação com os constantes e crescentes déficits nas contas públicas. A este respeito ver item 2.3 (supra), esp. notas 93 e 94. com 2010, totalizando 175.392 procedimentos iniciados, incluídos neste total tanto os concursos públicos quanto o ajuste direto. No entanto, quando se verifica o valor total, percebe-se queda nos gastos públicos, já que em 2013 o valor total foi de 7,1 mil milhões de euros. A queda é, ainda, mais acentuada quando se verificam os contratos celebrados e reportados ${ }^{129}$ em 2013, que correspondem a 157.775 procedimentos com 4,153 mil milhões de euros em termos de valores contratuais ${ }^{130}$.

No que diz respeito à distribuição geográfica dos contratos, o distrito de Lisboa desponta como aquele em que mais foram realizados procedimentos concursais, com um total de 21.685. Em seguida, aparecem o distrito do Porto (11.616) e o de Coimbra, com 5.483 - seguido de perto pelo distrito de Faro, com 5.430 procedimentos concursais. Os distritos de Lisboa e de Porto também ficam em $1^{\circ}$ e $2^{\circ}$ lugares em termos de valores gastos - respectivamente 931.364.866,86 euros e 536.812.403,05 euros. O distrito de Beja aparece em $3^{\circ}$ lugar, tendo gasto em 2013 250.881.950,64 euros, e em $4^{\circ}$ lugar vem a Região Autônoma da Madeira, com gasto total de 219.376.762,37 euros em contratos públicos. Vale, ainda, destacar que o distrito de Beja tem o contrato público mais caro de Portugal, já que na média cada contrato foi adjudicado pelo montante de 161.963,82 euros. Em outra ponta, com o contrato público mais barato aparece o distrito de Coimbra, que na média adjudicou seus contratos por 32.704,65 euros ${ }^{131}$.

129 Em nota, o relatório afirma que "cumpre alertar (como tem sido feito nos relatórios precedentes) para a possibilidade de os contratos reportados não serem, efetivamente, todos os contratos celebrados por entidades adjudicantes. Para além de entidades que possam não ter procedido ao registo dos seus contratos por desconhecimento, ou por outras razões, existem outros contratos que, atenta a natureza e o enquadramento jurídico, poderão não ter sido integralmente reportados ao Portal BASE, designadamente: a) Os contratos cujo preço contratual seja inferior a 5.000 euros; b) Os contratos de aquisição de serviços de água e energia elétrica; c) Os contratos das entidades inseridas nos sectores especiais (água, energia, transportes e serviços postais) abaixo dos limiares comunitários; d) Os contratos excluídos nos termos do artigo $4 .^{\circ}$ do CCP; e) Os contratos resultantes de procedimentos não sujeitos à parte II do CCP, nos termos do respetivo artigo 5. (ex: contratação 'in house')". PORTUGAL. Portal BASE. Contratação pública em Portugal 2013, 2015. Disponível em: <http://www.base.gov.pt/mediaRep/ inci/files/base_docs/RelContratosPublicos_2013.pdf >. Acesso em: 23 jul. 2015. p. 17, nota 16.

130 PORTUGAL. Portal BASE. Contratação pública em Portugal 2013, 2015. Disponível em: <http://www.base.gov.pt/mediaRep/ inci/files/base_docs/RelContratosPublicos_2013.pdf>. Acesso em: 23 jul. 2015. p. 11.

131 PORTUGAL. Portal BASE. Estatísticas: gráfico geográfico. Disponível em: <http://www.base.gov.pt/Base/pt/Estatisticas/ 
Impende destacar também que o relatório afirma que houve aumento do gasto público em relação a 2012 mas queda em relação a $2011^{132}$, o que pode ser entendido como resultado da crise econômica, por um lado, e das medidas de austeridade decorrentes do PAEF, por outro. Da mesma maneira, chama a atenção o fato de que houve aumento do número de contratos referentes à aquisição de bens e serviços - em tese contratos mais baratos em termos individuais -, correspondendo estes a $91,6 \%$ do número total dos contratos e a $62,3 \%$ do montante contratual, ao passo em que reduziu-se o número de contratos vinculados à empreitada de obras públicas - que tendem a ser mais dispendiosos ${ }^{133}$.

Ainda, é importante ressaltar que em 2013 os contratos públicos por meio do ajuste direto representaram $83,5 \%$ dos contratos celebrados, sendo seu valor correspondendo a 50,1\% do montante total. Verifica-se, neste sentido, que o ajuste direto é utilizado em $87,3 \%$ do número de contratos de obras públicas e em $83,2 \%$ do total dos contratos de bens e serviços, ainda que em termos de montante o ajuste direto corresponda a $35,1 \%$ dos contratos de obras públicas e a $59,2 \%$ dos contratos de bens e serviços ${ }^{134}$.

No que diz respeito ao critério de adjudicação, tem-se que $71,1 \%$ do número total de contratos utilizaram-se do critério do preço mais baixo, correspondendo tais contratos a $59,6 \%$ dos montantes contratuais. O próprio relatório informa que "a tendência observada nos últimos três anos aponta para o cada vez maior recurso ao critério do "preço mais baixo", já que em 2011 tal critério foi utilizado para a definição de $47,7 \%$ dos contratos adjudicados. O relatório traz ainda que em 2013 o valor médio dos contratos que tiveram como critério o preço mais baixo foi de 276.831 euros, enquanto o valor médio dos contratos que tiveram como critério a proposta economicamente mais vantajosa foi de 462.505 euros $^{135}$.

GraficoGeografico>. Acesso em: 25 jul. 2015.

132 PORTUGAL. Portal BASE. Contratação pública em Portugal 2013, 2015. Disponível em: <http://www.base.gov.pt/mediaRep/ inci/files/base_docs/RelContratosPublicos_2013.pdf >. Acesso em: 23 jul. 2015. p. 17-18.

133 PORTUGAL. Portal BASE. Contratação pública em Portugal 2013, 2015. Disponível em: <http://www.base.gov.pt/mediaRep/ inci/files/base_docs/RelContratosPublicos_2013.pdf $>$. Acesso em: 23 jul. 2015. p. 22-23.

134 PORTUGAL. Portal BASE. Contratação pública em Portugal 2013, 2015. Disponível em: <http://www.base.gov.pt/mediaRep/ inci/files/base_docs/RelContratosPublicos_2013.pdf $>$. Acesso em: 23 jul. 2015. p. 28-30, passim.

135 PORTUGAL. Portal BASE. Contratação pública em Portugal
O relatório de 2013 é detalhista a respeito dos contratos que tiveram como critério de adjudicação a proposta economicamente mais vantajosa. Nesse sentido é interessante destacar que o fator "preço" (ou análogo) teve preponderância nos contratos públicos com este critério de adjudicação, sendo o mesmo responsável pela definição de $61,93 \%$ dos procedimentos concursais abertos em 2013. Dessa maneira tem-se que em $89 \%$ dos contratos adjudicados em 2013 o critério utilizado foi ou o preço mais baixo ou, no caso dos contratos que tiveram como critério a proposta economicamente mais vantajosa, o fator "preço" foi o critério preponderante ${ }^{136}$.

Por fim, é forçoso ressaltar que, à semelhança do relatório de 2010, o de 2013 não traz nenhuma referência explícita a quais critérios socioambientais eventualmente foram utilizados nos contratos celebrados no período.

\subsection{Análise comparativa dos relatórios}

É interessante notar que o relatório de 2010 apresenta-se como extremamente simplificado e curto quando comparado ao relatório de 2013. Tal simplicidade já se apresenta a partir do próprio número de páginas (9 páginas no relatório de 2010 contra 100 páginas no de 2013) mas não se limita a isto: o relatório de 2013 traz uma análise muito mais aprofundada a partir de inúmeros critérios que não estavam presentes no relatório de $2010^{137}$.

Apesar disso, é possível perceber algumas diferenças significativas no que diz respeito à contratação pública realizada pelo Estado português quando se comparam os dois momentos apresentados. A primeira delas diz respeito à inversão percentual do número de contratos

2013, 2015. Disponível em: <http://www.base.gov.pt/mediaRep/ inci/files/base_docs/RelContratosPublicos_2013.pdf>. Acesso em: 23 jul. 2015. p. 61-3.

136 PORTUGAL. Portal BASE. Contratação pública em Portugal 2013, 2015. Disponível em: <http://www.base.gov.pt/mediaRep/ inci/files/base_docs/RelContratosPublicos_2013.pdf >. Acesso em: 23 jul. 2015. p. 63-5, passim. O próprio relatório ressalta ainda que o fato das entidades adjudicantes terem dado importância quase que exclusiva ao fator "preço" é uma prova das restrições orçamentais pelas quais tais entidades passam.

137 Uma possível explicação para esta diferença se refere ao fato de que o relatório sobre 2010 foi o primeiro produzido pelo Portal BASE, momento em que o sistema ainda estava se adaptando à realidade político-administrativa do Estado português, e por tal motivo limitou-se tal relatório a trazer informações básicas sobre a contratação pública - sendo, portanto, descritivo e não analítico. 
públicos em termos de tipos de contratos adjudicados: enquanto em 2010 a maioria dos contratos no que se refere ao montante (61\%) foi no âmbito das obras públicas, em 2013 houve a inversão deste número, com $62 \%$ do montante total dos contratos sendo vinculados a contratos de bens e serviços. Uma possível explicação para isto está no fato de que os contratos de obras públicas são mais caros do que os de bens e serviços ${ }^{138}$. Ora, em tempos de restrição econômica ao gasto público - como era o caso de Portugal em 2013 - parece ser natural que a contratação pública se dirija mais para a aquisição de bens e serviços - menos dispendiosos - do que para a aquisição de obras públicas.

Outro fato que decorre claramente dos relatórios diz respeito à redução do valor médio dos contratos. Enquanto em 2010 todos os contratos (tanto de bens e serviços quanto de obras públicas) tiveram custo médio de 137.418 euros, em 2013 o valor médio foi de 26.322 euros. Portanto, ainda que tenha havido aumento do número total de contratos, o gasto do Estado português com os mesmos foi consideravelmente menor. Novamente, parece plausível creditar tal redução às constrições econômicas decorrentes do acordo de austeridade fiscal celebrado pelo Estado português com a Troika.

Ainda no que se refere à redução do gasto público com as contratações, impende destacar que o relatório de 2013 apresenta, em inúmeros momentos, comparações com os anos anteriores, nomeadamente 2012 e $2011^{139}$. Nesse sentido as restrições econômicas são também visíveis, especialmente quando se verifica que em 2013 gastou-se mais que em 2012 (4.153 milhões contra 3.477 milhões, respectivamente) mas menos que em 2011 (4.765 milhões de euros) ${ }^{140}$. O valor médio dos contratos de obras públicas, também, seguiu a mesma lógica: foi maior que em 2012, mas menor que 2011, enquanto o de bens e serviços foi menor que nos dois anos anteriores ${ }^{141}$.

138 Os contratos de obras públicas em 2010 tiveram custo médio de 503.803 euros, enquanto os de bens e serviços tiveram custo médio de 64.245 euros neste mesmo ano. Já em 2013, o custo médio dos contratos de obras públicas foi de 118.228 euros, com os contratos de bens e serviços tendo o valor médio de 17.896 euros.

139 Mas raramente o faz com o ano de 2010, talvez pelo relatório deste ano ter sido, como já dito, extremamente simplificado quando comparado aos demais.

140 PORTUGAL. Portal BASE. Contratação pública em Portugal 2013, 2015. Disponível em: <http://www.base.gov.pt/mediaRep/ inci/files/base_docs/RelContratosPublicos_2013.pdf>. Acesso em: 23 jul. 2015. p. 18.

141 PORTUGAL. Portal BASE. Contratação pública em Portugal
Um aspecto relevante a ser destacado com base no relatório de 2013 diz respeito à concorrência. É inegável que este é um princípio fundamental para o desenvolvimento do mercado interno da União Europeia, ainda mais quando se considera que uma das razões de existência do bloco, desde sua origem com o Tratado de Roma, era facilitar o comércio entre os Estados signatários ${ }^{142}$. O princípio da concorrência é, atualmente, tão importante para a União Europeia que o próprio Tratado de Funcionamento da União Europeia traz uma parte específica - o Título VII - para tratar das regras comuns relativas à concorrência ${ }^{143}$. É nesse sentido que as diretivas de 2004 traziam inúmeras disposições acerca da concorrência, o que logicamente foi replicado nas diretivas de 2014. Em suma, não se pode pressupor um comércio verdadeiramente livre se não for garantida a concorrência entre as partes não apenas por ser a concorrência a concretização do princípio da liberdade individual - no sentido de que uma empresa precisa ser livre para oferecer seus produtos e/ou serviços - mas também por ser por meio da concorrência que se consegue maior economia, o que parece ser, sem sombra de dúvidas, benéfico para todos os cidadãos.

Nessa acepção, é importante destacar que a concorrência não pode ser apenas prevista no ordenamento jurídico de um Estado - ou, no caso, da União Europeia -, mas ela precisa ser incentivada de maneira a fazer com que efetivamente seja possível ao maior número de em-

2013, 2015. Disponível em: <http://www.base.gov.pt/mediaRep/ inci/files/base_docs/RelContratosPublicos_2013.pdf>. Acesso em: 23 jul. 2015. p. 24-25

142 Parece não haver dúvidas de que facilitação do mercado interno prevista no artigo $3^{\circ}$ do Tratado de Roma pressupunha a existência da concorrência entre os entes econômicos. MARTINS, Ana Maria Guerra. Manual de direito da União Europeia. Coimbra: Almedina, 2014. p. 207; ESTORNINHO, Maria João. Curso de direito dos contratos públicos: por uma contratação pública sustentável. Coimbra: Almedina, 2014. p. 58-64.

143 Isto sem desconsiderar o fato de que o Tratado de Funcionamento da União Europeia traz explicitamente, já em seu artigo $3^{\circ}$, alínea $b$, que a União dispõe de competência para estabelecer as "regras de concorrência necessárias ao funcionamento do mercado interno". UNIÃO EUROPEIA. Versões consolidadas do Tratado da União Europeia e do Tratado sobre o Funcionamento da União Europeia. Tratado da União Europeia (Versão consolidada). Tratado sobre o Funcionamento da União Europeia (Versão consolidada). Protocolos. Anexos. Declarações anexadas à Ata Final da Conferência Intergovernamental que adotou o Tratado de Lisboa assinado em 13 de dezembro de 2007 - Quadros de correspondência. Jornal Oficial, n. C 326, de 26 outubro 2012, p. 1-390. Disponível em: < http:// eur-lex.europa.eu/legal-content/PT/TXT/?uri=CELEX:12012E/ TXT>. Acesso em: 24 jul. 2015. p. 1-390. 
presas privadas a participação em concursos públicos ${ }^{144}$. Por outras palavras, torna-se necessário fazer com que o maior número possível de concorrentes participem dos procedimentos adjudicatórios de maneira a se evitar eventuais práticas anticoncorrenciais que possam pôr em causa o próprio procedimento concorrencial ${ }^{145}$.

Contudo, apesar de ser um princípio da União Europeia e de ser norma constitucional do Estado português ${ }^{146}$, parece haver dificuldade na concretização da concorrência ampla no que se refere às contratações públicas, como se verifica no relatório: em média houve, apenas, 2,6 propostas por cada procedimento de contratação, com os contratos de obras públicas recebendo 3,3 propostas por procedimento e os de bens e serviços recebendo 2,4 propostas $^{147}$.

Quando se analisam os contratos por tipo, percebe-se um número elevado de concorrentes nos procedimentos concursais típicos (média de 7,3 concorrentes);

144 Assim se manifestou o Tribunal de Contas de Portugal acerca da importância do princípio da concorrência nas contratações públicas: "O respeito pelo princípio da concorrência e seus corolários subjaz a qualquer actividade de contratação pública por força de imperativos comunitários, por directa decorrência de normas constitucionais, por previsão da lei aplicável à contratação e por imposição da legislação financeira e dos deveres de prossecução do interesse público e de boa gestão. Assim, na formação dos contratos públicos devem ser usados procedimentos que promovam o mais amplo acesso à contratação dos operadores económicos nela interessados". PORTUGAL. Tribunal de Contas. Acórdão n. 40/2010. Processo n. 1303/201003. 1ª S/SS. 03 de novembro de 2010. Disponível em: <http://www.tcontas.pt/pt/ actos/acordaos/2010/1sss/ac040-2010-1sss.pdf>. Acesso em: 29 jul. 2015. p. 1.

145 Dentre as principais práticas anticoncorrenciais destacam-se os seguintes: a) supressão de propostas; b) propostas complementares ou propostas sombra; c) propostas rotativas; d) subcontratação. Tais práticas são detalhadas em RODRIGUES, Nuno Cunha. $A$ contratação pública como instrumento de política económica. Coimbra: Almedina, 2015. p. 359-361; PORTUGAL. Autoridade da Concorrência. O programa de clemência. O que são cartéis. Disponível em: <http:// www.concorrencia.pt/vPT/Praticas_Proibidas/O_programa_de_ clemencia/Tipos_de_carteis/Paginas/O-que-sao-carteis.aspx $>$. Acesso em: 29 jul. 2015.

146 "Artigo 81. Incumbe prioritariamente ao Estado no âmbito económico e social: [...] f) Assegurar o funcionamento eficiente dos mercados, de modo a garantir a equilibrada concorrência entre as empresas, a contrariar as formas de organização monopolistas e a reprimir os abusos de posição dominante e outras práticas lesivas do interesse geral". PORTUGAL. Assembleia da República. Constituição da República Portuguesa. VII Revisão Constitucional (2005). Disponível em: <http://www.parlamento.pt/Legislacao/Documents/ constpt2005.pdf >. Acesso em: 25 jun. 2015. p. 28.

147 PORTUGAL. Portal BASE. Contratação pública em Portugal 2013, 2015. Disponível em: <http://www.base.gov.pt/mediaRep/ inci/files/base_docs/RelContratosPublicos_2013.pdf >. Acesso em: 23 jul. 2015. p. 56-57. contudo, nos acordos-quadro aparecem, apenas, 3,4 concorrentes por procedimento e no ajuste direto o número cai para 2 concorrentes por procedimento ("sendo que, no caso das obras públicas, o número médio já foi inferior a 2"; acrescente-se que "no caso dos ajustes diretos para a aquisição de bens e serviços, em 58,7\% dos procedimentos apenas foi apresentada uma proposta"). O relatório destaca, ainda, que o número médio de concorrentes em 2013 (2,6) foi ainda menor do que em 2012 (quando havia em média 3,1 concorrentes por procedimento $)^{148}$.

Ora, parece claro que o aspecto formal da concorrência é garantido tanto pelas diretivas europeias quanto pela legislação portuguesa, especificamente no que concerne aos procedimentos previstos no CCP. A concorrência parece, também, garantida especialmente quando se considera a utilização das plataformas eletrônicas, por um lado - o que possibilita o aumento da concorrência já que as propostas podem ser encaminhadas a partir de qualquer lugar, sem limitações físicas - e pela própria divulgação dos relatórios anuais, os quais servem para a publicidade dos contratos púbicos e para o empoderamento não apenas do cidadão mas também das empresas que porventura tenham interesse de, no futuro, participar de concursos públicos semelhantes aos já realizados.

Contudo, quando se verifica o número de concorrentes vislumbra-se que a concorrência parece não ser tão grande quanto a esperada. Não é objetivo deste texto apresentar e debater as possíveis causas do baixo número de concorrentes em relação às propostas feitas pelo Estado português, mas talvez seja possível afirmar que o mecanismo do contrato público como um incentivador do mercado pode não ser efetivo em Portugal. Ainda que não fossem objetivos explícitos das diretivas de 2004 - às quais tais contratos de 2013 se submetem - a promoção e manutenção do nível de emprego, tais objetivos já poderiam estar presentes nos contratos públicos celebrados naquele período. Seria, portanto, plausível esperar que tais contratos pudessem trazer como resultado algum impacto na economia portuguesa.

Não foi isto, contudo, o que se verificou. Seja por haver poucos concorrentes, seja por ter havido redução

148 PORTUGAL. Portal BASE. Contratação pública em Portugal 2013, 2015. Disponível em: <http://www.base.gov.pt/mediaRep/ inci/files/base_docs/RelContratosPublicos_2013.pdf>. Acesso em: 23 jul. 2015. p. 58-60. 
do valor médio dos contratos, o fato é que a contratação pública representou em 2013 apenas 2,5\% do PIB de Portugal, valor extremamente baixo especialmente quando comparado à estimativa feita pela Comissão Europeia a respeito do país - de que as contratações públicas deveriam corresponder a pelo menos 10,68\% do PIB em 2012. Mesmo em anos anteriores a porcentagem da contratação pública no PIB português foi muito baixa (2,79\% em 2011 e 2,11\% em 2012), o que parece demonstrar que a contratação pública pode não ser eficaz no desenvolvimento econômico como se espera ${ }^{149}$.

O último ponto relevante do relatório diz respeito ao critério utilizado para a adjudicação dos contratos públicos em 2013. Conforme já mostrado neste texto ${ }^{150}$, tanto as diretivas de 2004 quanto o CCP trazem a possibilidade de estabelecimento de dois critérios distintos para a definição da proposta vencedora, quais sejam, o preço mais baixo e a proposta economicamente mais vantajosa. Nesse sentido, importa destacar que $71,1 \%$ dos contratos públicos - o que corresponde a 59,6\% do montante total - foram adjudicados com base no critério do preco mais baixo - critério este que, conforme o relatório, também foi utilizado em 2012 como o principal na definição do concorrente vencedor. Da mesma maneira, destaca-se que de 2012 para 2013 houve uma queda no valor médio dos contratos adjudicados com base no critério do preşo mais baixo, que passou de 367.523 euros para 276.831 euros $^{151}$.

O que chama a atenção, contudo, são aqueles contratos adjudicados com base no critério da proposta economicamente mais vantajosa. Conforme a alínea $a$ do $\mathrm{n}^{\circ} 1$ do art. $53^{\circ}$ da diretiva 2004/18/CE, esse tipo de proposta se caracteriza pela possibilidade dada à entidade adjudicante de estabelecer outros critérios que não exclusivamente o preço - tais como a qualidade, as características ambientais do produto, o custo de utilização e o serviço pós-venda, dentre outros ${ }^{152}$ - de maneira a considerar

149 PORTUGAL. Portal BASE. Contratação pública em Portugal 2013, 2015. Disponível em: <http://www.base.gov.pt/mediaRep/ inci/files/base_docs/RelContratosPublicos_2013.pdf $>$. Acesso em: 23 jul. 2015. p. 18-19.

150 Ver item 1.1.

151 PORTUGAL. Portal BASE. Contratação pública em Portugal 2013, 2015. Disponível em: <http://www.base.gov.pt/mediaRep/ inci/files/base_docs/RelContratosPublicos_2013.pdf >. Acesso em: 23 jul. 2015. p. 61.

152 UNIÃO EUROPEIA. Directiva 2004/18/CE do Parlamento Europeu e do Conselho, de 31 de Março de 2004. Relativa à coordenação dos processos de adjudicação dos contratos de empreitada de obras públicas, dos contratos públicos de fornecimento e dos con- tais critérios na definição de qual será a proposta vencedora. Nos contratos desse tipo, fica o Estado autorizado a contratar aquele concorrente que não necessariamente ofereça o preço mais baixo, mas sim que ofereça a proposta que apresente a melhor relação custo $x$ benefício para o Estado ${ }^{153}$.

Entretanto, o que se vê com base no relatório é que não apenas o critério da proposta economicamente mais vantajosa foi menos utilizado como critério de escolha da proposta vencedora - tendo este critério sido utilizado em apenas $28,9 \%$ das propostas ${ }^{154}$-, mas também que nos concursos que tiveram este critério como o definidor do vencedor o subfator "preço" foi o mais utilizado na definição das propostas vencedoras. O relatório afirma que, nesse tipo de proposta, "o fator preço, não sendo o único fator de apreciação, representou mais de metade da ponderação" nos contratos públicos assim adjudicados ${ }^{155}$.

Em outras palavras, parece que o Estado português preferiu escolher as propostas apresentadas com base no critério do preço mais baixo e, dentre as demais - ou seja, dentre aquelas cujo critério foi o da proposta economicamente mais vantajosa - também escolheu o subfator preço como o principal mecanismo definidor da proposta vencedora. Dessa maneira, o que se viu em 2013 foi que ao fim e ao cabo $89 \%$ dos contratos públicos adjudicados tiveram o critério "preço" como fator preponderante ${ }^{156}$ - seja de maneira direta, na forma dos

tratos públicos de serviços. Jornal Oficial, n. L 134, de 30 de abril de 2004, p. 114-240. Disponível em: < http://eur-lex.europa.eu/legalcontent/PT/TXT/?uri=CELEX:32004L0018>. Acesso em: 20 jul. 2015. p. $114-240$.

153 Como explicitado antes neste texto, é no âmbito das propostas economicamente mais vantajosas que podem surgir contratos com preocupações socioambientais.

154 PORTUGAL. Portal BASE. Contratação pública em Portugal 2013, 2015. Disponível em: <http://www.base.gov.pt/mediaRep/ inci/files/base_docs/RelContratosPublicos_2013.pdf>. Acesso em: 23 jul. 2015. p. 62.

155 Diz o relatório que "o fator preço ou análogo teve um peso superior a meio em $61,93 \%$ dos procedimentos concursais abertos no ano de 2013". Vale ainda destacar que os contratos públicos celebrados com base na proposta economicamente mais vantajosa tiveram valor médio de 462.505 euros - ou seja, são em média $62 \%$ mais dispendiosos do que os contratos com preço mais baixo. PORTUGAL. Portal BASE. Contratação pública em Portugal 2013, 2015. Disponível em: <http://www.base.gov.pt/mediaRep/inci/files/base_docs/ RelContratosPublicos_2013.pdf>. Acesso em: 23 jul. 2015. p. 63-65. 156 PORTUGAL. Portal BASE. Contratação pública em Portugal 2013, 2015. Disponível em: <http://www.base.gov.pt/mediaRep/ inci/files/base_docs/RelContratosPublicos_2013.pdf>. Acesso em: 23 jul. 2015. p. 65. 
contratos adjudicados com base no critério do preço mais baixo, seja de maneira indireta, na forma de um subfator dos contratos adjudicados com base no critério da proposta economicamente mais vantajosa.

Percebe-se, dessa maneira, que o critério exclusivamente econômico foi priorizado pelo Estado português em detrimento de critérios socioambientais na adjudicação dos contratos públicos. Assim, se, por um lado, os Estados-membros da União Europeia foram incentivados a se utilizar das contratações públicas como um mecanismo que pudesse contrabalançar os efeitos negativos da crise econômica; por outro, o fizeram tendo como pano de fundo as medidas de austeridade que, em maior ou menor grau, tiveram de seguir. O caso português parece ser emblemático no diz respeito a qual fator é dada prioridade em momento de crise econômica, especialmente se se considera a situação de obrigatoriedade de aceitação de imposições externas a respeito do corte nos gastos públicos.

\subsection{Análise de casos concretos}

Com base no que foi exposto acima, apresenta-se como claro que o componente "preço" foi o mais importante utilizado como critério de adjudicação dos contratos públicos em Portugal nos últimos 4 anos. Contudo, parece também ser interessante verificar algumas características dos contratos que tenham utilizado como critério de adjudicação algum fator relacionado à área socioambiental.

Para tanto será apresentada a seguir análise de contratos públicos celebrados pelo Estado português ${ }^{157} \mathrm{e}$ disponibilizados no Portal BASE ${ }^{158}$. Os contratos aqui

157 A análise foi feita com base nos anúncios de concurso público publicados no Diário da República dos contratos já celebrados entre 2010 e 2015. Optou-se pela análise do anúncio do concurso público e não do contrato já celebrado por ser no anúncio que os critérios socioambientais devem estar presentes, conforme explicitado no item 1.2 deste texto.

158 A pesquisa foi realizada no dia 27 de julho de 2015 a partir do Portal BASE (disponível em <http://www.base.gov.pt $>$ ). Ao acessar-se o site aparece já de início a opção para pesquisa de anúncios de contratos públicos. Optou-se pela opção "pesquisa avançada". Considerando-se que o número total de contratos públicos é elevado, o que impediria a análise individualizada, optou-se por delimitar-se a pesquisa apenas à opção "concurso público" na tela que se apresenta a seguir, em "tipo de procedimento". Importa destacar que além desta opção estão disponíveis também as seguintes: "ajuste direto", "concurso limitado por prévia qualificação", "procedimento de negociação", "diálogo concorrencial", "ao abrigo do acordo-quadro (art. 258 ${ }^{\circ}$ )" e "ao abrigo do acordo-quadro (art. 259 ${ }^{\circ}$ )". Em seguida analisados foram escolhidos utilizando-se o Vocabulário Comum para os Contratos Públicos (CPV) ${ }^{159}$ conforme o Regulamento (CE) No 213/2008 ${ }^{160}$. Nesse sentido utilizaram-se os seguintes CPVs para a realização desta pesquisa:

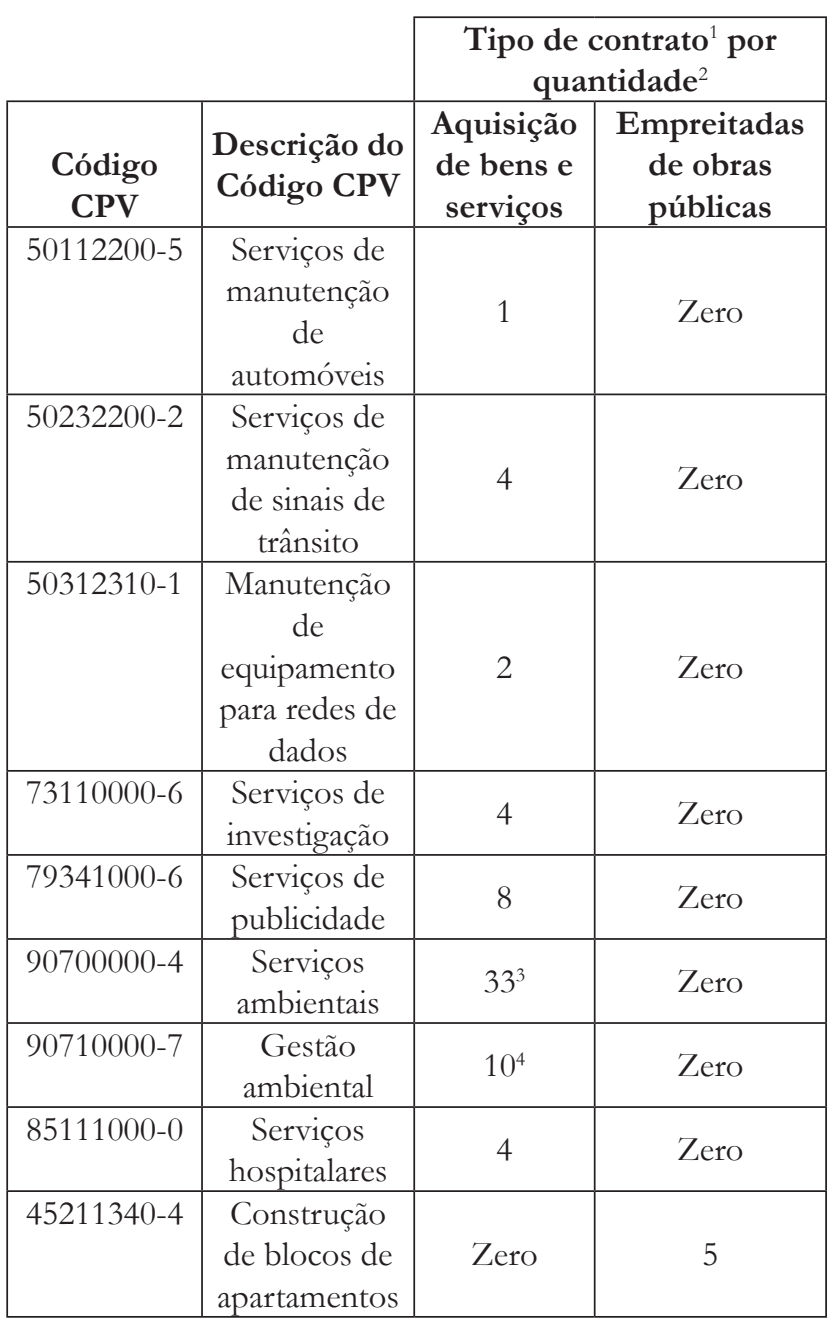

aplicaram-se os respectivos códigos do Vocabulário Comum para os Contratos Públicos (CPV), conforme quadro a seguir. Por fim, em cada contrato disponível clicou-se na opção "detalhe do anúncio" e em seguida na opção "ligação para DRE", de maneira a obter-se a respectiva edição do Diário da República com o anúncio do concurso público.

159 A escolha destes códigos CPV deu-se de maneira aleatória, sem preferência prévia de uns em detrimento de outros.

160 UNIÃO EUROPEIA. Regulamento (CE) n. 213/2008 da Comissão de 28 de novembro de 2007 que altera o Regulamento (CE) n. 2195/2002 do Parlamento Europeu e do Conselho. Relativo ao Vocabulário Comum para os Contratos Públicos (CPV), e as Directivas do Parlamento Europeu e do Conselho 2004/17/CE e 2004/18/CE, relativas aos processos de adjudicação de contratos, no que respeita à revisão do CPV. Jornal Oficial da União Europeia, n. L 74/1, de 15 março de 2008. Disponível em: < http:/ / eur-lex.europa. eu/LexUriServ/LexUriServ.do?uri=OJ:L:2008:074:0001:0375:PT:P DF>. Acesso em: 24 jul. 2015. 


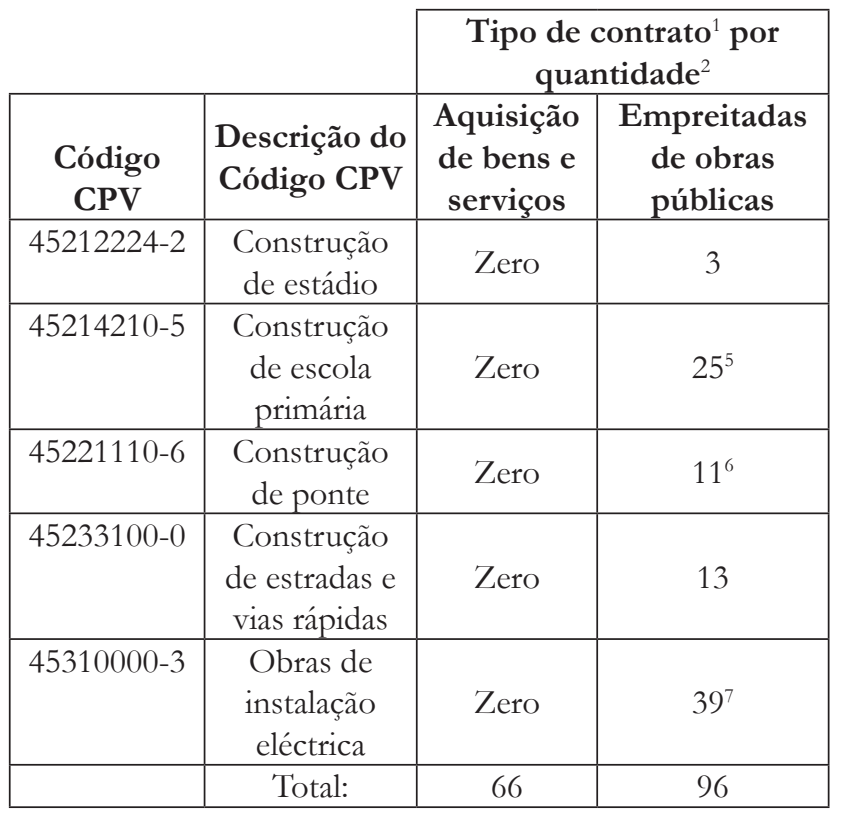

Os 162 contratos apresentados acima foram analisados um a um especificamente no que diz respeito ao critério de adjudicação, o qual geralmente vem no item $\mathrm{n}^{\circ}$ 12 dos respectivos anúncios de contratação. $O$ primeiro ponto que precisa ser clarificado é que em 74 anúncios de procedimento o critério utilizado foi o do preşo mais baixo, de maneira que estes foram automaticamente descartados na análise que se segue ${ }^{161}$. Além destes foram descartados também 11 anúncios de procedimento que não traziam explicitamente qual o critério a ser utilizado na adjudicação ${ }^{162}$.

Dessa maneira, dos 162 anúncios originalmente pesquisados restaram 77 anúncios de contratação que utilizaram a proposta economicamente mais vantajosa como critério de adjudicação, correspondente a $48 \%$ do total pesquisado. Esses contratos foram separados em três grupos conforme a ponderação dada ao subfator "preço": aqueles que estabeleceram que tal subfator corresponderia a no mínimo 50\% dos critérios; aqueles que estabeleceram que o subfator "preço" corresponderia a até $50 \%$ dos critérios; e aqueles que não definiram explicitamente qual seria o peso do subfator "preço".

161 Já que o que importa aqui é analisar os critérios socioambientais eventualmente presentes nos anúncios de contratos públicos cujo critério de adjudicação seja o da proposta economicamente mais vantajosa.

162 Estes casos tratavam-se, principalmente, de anúncios de procedimento antigos, geralmente dos anos de 2009 ou de 2010. Nestes casos o anúncio dos concursos indicou a plataforma eletrônica $<$ www.vortal.pt $>$ como o local no qual os critérios estariam disponíveis. Por ser uma plataforma fechada apenas a entidades adjudicantes e adjudicatárias não foi possível analisar estes anúncios.
Em consonância com o que foi anteriormente apresentado com base nos relatórios, em 45 anúncios de contratação - ou seja, em 59\% dos 77 anúncios que utilizaram a proposta economicamente mais vantajosa como critério de adjudicação - o subfator "preço" teve peso igual ou maior que $50 \%$ para a definição da proposta vencedora. Por sua vez, 19 anúncios remeteram os interessados ao caderno de encargos, sem deixar explícito no Diário da República quais seriam os subfatores de ponderação ${ }^{163}$.

Apenas 13 dos 77 anúncios - ou seja, 17\% daqueles que utilizaram a proposta economicamente mais vantajosa como critério de adjudicação - indicaram que o subfator "preço" ficaria abaixo dos 50\% de maneira a dar importância a outros subfatores. Em 9 anúncios, a valoração do restante que não o preço foi feita de maneira genérica por meio da utilização das expressões "valia técnica" ou "qualidade técnica", sem, contudo, explicitar o que estas significam. O subfator "prazo" também apareceu em alguns casos como coeficiente de ponderação com mais peso que o subfator "preço".

Parece claro que os quesitos socioambientais não aparecem de maneira explícita nos anúncios de concurso público realizados pelo Estado português, tanto em nível nacional quanto em nível local. Ainda que a análise aqui apresentada se limite àquilo que está explícito nos anúncios, já que não temos acesso aos cadernos de encargos dos respectivos concursos - disponíveis, em geral, no âmbito das plataformas virtuais, conforme já explicitado -, parece ser possível afirmar que o contexto de crise econômica por qual passou Portugal, associado às restrições de gastos públicos decorrentes do programa de austeridade ao qual este Estado se submeteu, fez com que a preocupação se voltasse mais para a economia de recursos públicos do que ao incentivo ao desenvolvimento socioambiental por meio de ações estimuladas pelo próprio Estado por meio das contratações públicas.

As exceções a essa ausência explícita de critérios socioambientais nos anúncios dos contratos públicos são poucas. Nesse sentido apresenta-se aqui o anúncio de procedimento $n^{\circ}$ 4372/2013, feito pela empresa “Águas

163 Em geral tais anúncios apresentaram o seguinte texto: "Factores e eventuais subfactores acompanhados dos respectivos coeficientes de ponderação: Os critérios enunciados no caderno de encargos, no convite à apresentação de propostas ou para participar na negociação ou na memória descritiva”. 
de Santo André, S. A." no município de Vila Nova de Santo André. O contrato teve por objeto a realização de colheita e análises físico-químicas, microbiológicas e fitoplanctônicas para controle de qualidade da água no subsistema de abastecimento de água da cidade. $\mathrm{O}$ anúncio traz como critério de ponderação a "apreciação da qualificação profissional”, com peso de $10 \%$, o que pode ser entendido como um critério socioambiental por levar em consideração a qualificação dos trabalhadores que realizariam o serviço.

Da mesma forma, destaca-se o anúncio de procedimento $n^{\circ}$ 4496/2014 feito pela EPAL - Empresa Portuguesa das Águas Livres, S. A. A empreitada "Estação Elevatória I de Castelo do Bode - Remodelação do quadro de média tensão (Normabloco)" trouxe como fator de ponderação a apresentação de um plano de trabalhos encadeado "com os planos de mão de obra e de equipamentos", com valoração de $10 \%$, o que, também, pode, em uma interpretação ampla, ser entendido como incentivo à qualificação da mão de obra a ser utilizada na empreitada.

Merece ser dada atenção também para o anúncio de procedimento $n^{\circ}$ 2082/2014, do Estado Maior do Exército, com o objetivo de remodelar a rede elétrica no Convento de Mafra. Ainda que nesta proposta o fator "preço" corresponda a $60 \%$ dos critérios de ponderação, a proposta traz o subfator "plano de mão de obra e meios humanos a afetar à obra", com peso de $15 \%$, o que pode ser visto como uma forma de estimular fatores sociais na implementação do contrato público.

O último anúncio de procedimento que merece destaque e que talvez se apresente como o que traz de maneira mais explícita, dentre aqueles analisados, os critérios socioambientais é o de $n^{\circ} 3235 / 2012$, lançado pelo município de Paredes, cujo objetivo era a prestação de serviços de limpeza pública urbana nas cidades de Paredes, Lordelo, Gandra e Rebordosa, Vilas de Baltar, Vilela, Cete, Recarei e Sobreira e Freguesia de Parada de Todeia. No anúncio em questão explicita-se que o fator "preço" tem ponderação de $50 \%$ e que o fator "qualidade técnica da proposta de limpeza urbana" corresponde aos demais $50 \%$. Este último, por sua vez, é subdividido nos subfatores "classificação do programa de trabalhos" (25\%), "classificação dos meios humanos envolvidos" (20\%) e "classificação da qualidade da estruturação da proposta e dos sistemas de qualidade/ambiente" ( $5 \%)$. No que concerne aos "meios hu- manos envolvidos", fala-se em "funcionários afetos à prestação de serviço" - um critério social - e, no último dos subfatores, fala-se em "proposta com metodologia que demonstre o cumprimento das normas ambientais e de higiene e segurança", que pode ser visto como um critério ambiental.

Em suma, o que se verifica, mesmo nesses anúncios de procedimento apresentados de maneira mais detalhada, é que não há a presença e a respectiva explicitação de critérios socioambientais como definidores daquela que virá a ser a proposta vencedora. Não apenas o fator "preço" é majoritariamente o subfator definidor dos contratos públicos como também os critérios socioambientais simplesmente não aparecem nos anúncios ou dependem de interpretação favorável a que certas expressões sejam entendidas como tais. Novamente, deve-se ressaltar que os cadernos de encargos não estão acessíveis, de maneira que a conclusão aqui apresentada se refere exclusivamente aos anúncios de procedimento divulgados oficialmente no Diário da República.

\section{Considerações finais}

É inegável o enorme papel que o Estado tem no sentido de fazer com que a sociedade abrace novas "visões de mundo", e este papel parece ter importância ainda maior no âmbito das políticas socioambientais chamadas de "sustentáveis". Tomando-se como exemplo o caso da garantia do direito ao meio ambiente - direito este difuso, ou seja, que é garantido ao mesmo tempo tanto ao indivíduo quanto à coletividade ${ }^{164}-$, compete ao Estado, por meio do governo, fazer com que o cidadão se conscientize da necessidade de proteção do meio ambiente.

Da mesma forma, em um modelo de Estado em que este deve garantir o bem-estar dos cidadãos, torna-se premente a implantação de políticas públicas que se configurem como incentivadoras do emprego, seja por meio direto - em que o próprio Estado é o con-

164 SARLET, Ingo Wolfgang; FENSTERSEIFER, Tiago. O papel do poder Judiciário brasileiro na tutela e efetivação dos direitos (e deveres) socioambientais. In: SILVA, Vasco Pereira da; SARLET, Ingo Wolfgang (Org.). Direito público sem fronteiras. Lisboa: ICJP, 2011. p. 11-63. p. 12-15 Disponível em: <http://www.icjp.pt/sites/ default/files/media/ebook_dp_completo2_isbn.pdf $>$. Acesso em: 27 jul. 2015. 
tratante -, seja por meio indireto, isto é, fomentando o desenvolvimento do mercado privado por meio de sua atuação na área econômica - basicamente por meio da tributação - ou na área administrativa - por meio de políticas públicas ${ }^{165}$.

No âmbito da União Europeia, não é diferente. Conforme já destacado, a atuação dos Estados-membros na esfera econômica apenas por meio da contratação pública varia entre $15 \%$ e $19 \%$ do PIB $^{166}$. É um montante elevado, especialmente se se considerar que a situação econômica vivida pelo bloco europeu nos últimos 6-8 anos, nomeadamente aquela vivida por alguns de seus Estados-membros, é de profunda crise econômica.

Seria de se imaginar, portanto, que a atuação incisiva do Estado poderia auxiliar com o término da crise econômica. Este, inclusive, é um dos argumentos que levaram à revisão das diretivas de 2004 acerca das contratações públicas, processo este que resultou nas diretivas de 2014. Em seu Considerando $n^{\circ} 2$ o texto da diretiva 2014/24/UE deixa explícito que a contratação pública é mecanismo relevante no âmbito da concretização da estratégia Europa $2020^{167}$, a qual, por sua vez, busca o equilíbrio entre o desenvolvimento econômico inclusivo - que combateria os males da crise econômica - ao mesmo tempo em que protegeria o meio ambiente para esta geração e para as futuras.

A mesma diretiva, em seu Considerando $n^{\circ} 47$, traz outro pilar respeitante à estratégia Europa 2020, qual seja, a de que as contratações públicas servem para estimular a "ecoinovação e a inovação social". Reverberando, também, a ideia de que "a aquisição de produtos, obras e serviços inovadores [... leva] à promoção de um

165 É importante chamar a atenção para o fato de que o investimento inicial em investigação e desenvolvimento de novas tecnologias é quase sempre realizado pelo Estado, com pouco investimento privado. A este respeito ver GEELS, Frank W. The impact of the financial-economic crisis on sustainability transitions: financial investment, governance and public discourse. Working paper n. 39. Welfare, wealth and work for Europe. 2013. Available at: < http://www.foreurope. $\mathrm{eu} /$ fileadmin/documents/pdf/Workingpapers/WWWforEurope_ WPS_no039_MS205.pdf>. Accessed: 22 jul. 2015. p. 10.

166 Ver nota 96 neste texto.

167 UNIÃO EUROPEIA. Diretiva 2014/24/UE do Parlamento Europeu e do Conselho, de 26 de fevereiro de 2014. Relativa aos contratos públicos de obras, fornecimentos ou serviços e que revoga a Diretiva 2004/18/CE. Jornal Oficial da União Europeia, n. L 94/65, de 28 de março de 2014. Disponível em: <http://eur-lex.europa. eu/legal-content/PT/TXT/?uri=CELEX:32014L0024>. Acesso em: 20 jul. 2015. crescimento económico sustentável"168, a diretiva deixa explícito o papel a ser desempenhado pelo Estado no sentido de levar a sociedade a transitar da economia "tradicional", baseada em combustíveis fósseis, para uma economia "sustentável", em que a proteção ao meio ambiente tenha importante papel não apenas na área específica da energia mas também, de maneira mais abrangente, na própria sociedade, a partir do momento em que a necessidade de investimento em novas áreas se transforme em sustentáculo do estímulo a novas tecnologias e, consequentemente, à sustentabilidade social por meio da abertura de vagas de emprego em novos setores da economia - inclusive naqueles "novos setores" que, eventualmente, surgissem em decorrência do desenvolvimento da economia "verde".

Contudo, o que se viu pela análise dos contratos públicos no caso português leva à conclusão de que as diretivas - tanto as de 2004 quanto as de 2014 - parecem não levar à efetiva economia sustentável como se deseja. Ainda que existam estímulos em âmbito europeu para a contratação socioambientalmente responsável, e ainda que o próprio Código dos Contratos Públicos traga também a necessária fundamentação legal para este tipo de contratação, o que se percebe é que o Estado português ainda não se utiliza destas possibilidades jurídicas para fazer a necessária transição do modelo econômico atual para a "nova economia" que se vislumbra como premente - não apenas em termos de proteção do ambiente, mas também em termos de proteção do próprio Estado de bem-estar social.

O primeiro aspecto destacado na pesquisa se refere ao fato de que o fator "preço" continua a ser o principal critério na definição do resultado da adjudicação dos contratos públicos. A preferência da entidade adjudicante por tal critério demonstra que a preocupação maior é com a economia de recursos em curto prazo e não, necessariamente, com a melhor relação "qualidade/preço”, como trazem as diretivas de 2014. É claro que as entidades adjudicantes precisam incluir, mesmo neste tipo de proposta, "um elemento de preço ou de

168 UNIÃO EUROPEIA. Diretiva 2014/24/UE do Parlamento Europeu e do Conselho, de 26 de fevereiro de 2014. Relativa aos contratos públicos de obras, fornecimentos ou serviços e que revoga a Diretiva 2004/18/CE. Jornal Oficial da União Europeia, n. L 94/65, de 28 de março de 2014. Disponível em: <http://eur-lex.europa. eu/legal-content/PT/TXT/?uri=CELEX:32014L0024>. Acesso em: 20 jul. 2015. 
custo", conforme o texto da diretiva 2014/24/UE ${ }^{169}$, mas o fato concreto é que, no caso português, e generalizando-se, utiliza-se, apenas, tal critério para a contratação pública.

É claro que, em relação ao aspecto jurídico, nada de ilegal está sendo feito, especialmente quando se lê, no Considerando $n^{\circ} 90$ da diretiva 2014/24/UE, que a "avaliação da proposta economicamente mais vantajosa também poderá ser efetuada apenas com base no preço ou na eficácia em termos de custos". Por outro lado, este mesmo termo Considerando traduz-se em que "a fim de incentivar uma maior orientação da contratação pública para a qualidade, os Estados-Membros deverão ser autorizados a proibir ou restringir a utilização exclusiva do preço ou do custo para avaliar a proposta economicamente mais vantajosa, quando o considerarem adequado" ${ }^{170}$.

Ou seja, Portugal poderia estimular a contratação pública sustentável por meio dos contratos públicos que levassem em consideração também outros critérios para além do preço principalmente quando se considera que são estes "outros critérios" que incentivarão os aspectos socioambientais das empresas contratantes - especialmente aqueles relacionados ao custo do ciclo de vida do produto adquirido. O que se verifica, porém, é que estes "outros critérios" não têm vindo a aparecer nos contratos celebrados pela Administração Pública portuguesa, o que permite a conclusão de que a inserção de aspectos socioambientais na economia lusitana não tem sido estimulada pelo Estado.

Outro ponto percebido com a pesquisa está vinculado à importância que as contratações públicas têm na economia portuguesa como um todo. Enquanto na média da União Europeia o Estado responde por 15\%$19 \%$ do PIB no que diz respeito às contratações públicas, em Portugal este percentual se limita a 2,5\% do PIB, o que parede demonstrar que as contratações públicas

169 UNIÃO EUROPEIA. Diretiva 2014/24/UE do Parlamento Europeu e do Conselho, de 26 de fevereiro de 2014. Relativa aos contratos públicos de obras, fornecimentos ou serviços e que revoga a Diretiva 2004/18/CE. Jornal Oficial da União Europeia, n. L 94/65, de 28 de março de 2014. Disponível em: < http://eur-lex.europa. eu/legal-content/PT/TXT/?uri=CELEX:32014L0024>. Acesso em: 20 jul. 2015.

170 UNIÃO EUROPEIA. Diretiva 2014/24/UE do Parlamento Europeu e do Conselho, de 26 de fevereiro de 2014. Relativa aos contratos públicos de obras, fornecimentos ou serviços e que revoga a Diretiva 2004/18/CE. Jornal Oficial da União Europeia, n. L 94/65, de 28 de março de 2014. Disponível em: < http://eur-lex.europa. eu/legal-content/PT/TXT/?uri=CELEX:32014L0024>. Acesso em: 20 jul. 2015. portuguesas estão muito aquém do que delas se espera. Mesmo quando se leva em consideração a expectativa da Comissão Europeia a respeito do peso das contratações públicas na economia portuguesa - expectativa esta que já era menor que a média europeia -, percebe-se que o resultado atingido na média dos três primeiros anos da década de 2010 é mais de quatro vezes menor em termos absolutos do que tal expectativa. Ou seja, é possível afirmar que alguma coisa não está correta nos contratos públicos de Portugal.

Destaca-se, ainda, outro ponto que se apresenta como um efeito deletério das contratações públicas, qual seja, o número relativamente reduzido de concorrentes. Não se pode afirmar que o modelo utilizado, com base no critério do preşo mais baixo, seja necessariamente o responsável pela diminuição do número de concorrentes. Ao contrário, seria de se esperar que a utilização do critério da proposta economicamente mais vantajosa pudesse diminuir o número de concorrentes, já que a indicação de critérios muito específicos levaria a que poucas empresas fossem capazes de satisfazê-los - ou seja, poderia, neste caso, haver verdadeiro direcionamento dos contratos públicos para empresas específicas ${ }^{171}$.

Entretanto, mesmo havendo a utilização do critério do preço mais baixo na maior parte dos contratos públicos - em tese mais aberto à concorrência -, o número médio de concorrentes nos procedimentos adjudicatórios se apresenta como sendo muito baixo, o que pode indicar o desinteresse, por parte das empresas privadas, em participar do procedimento concursal - o que, em verdadeiro círculo vicioso, leva à diminuição do peso das contratações públicas no PIB e, consequentemente, ao pequeno incentivo às mudanças socioambientais necessárias no momento atual.

Resta claro, portanto, que o momento de crise econômica vivido por Portugal se impôs frente ao necessário estímulo que deveria ser dado pelo Estado aos critérios socioambientais dos contratos públicos. Uma vez deparando-se com a necessidade de restrições orçamentárias, o administrador público claramente optou pela economia no gastos dos recursos públicos em detrimento da utilização da contratação pública como mecanismo de promoção de políticas públicas responsáveis socioambientalmente ${ }^{172}$. A proteção do meio am-

171 RODRIGUES, Nuno Cunha. A contratação pública como instrumento de política económica. Coimbra: Almedina, 2015. p. 363-365.

172 Destaca-se que essa ideia não corresponde a um juíro de valor, 
biente e o incentivo a aspectos sociais tornam-se - ao menos temporariamente - valores menos importantes ou menos essenciais quando comparados com outras áreas nas quais o Estado precisa atuar, nomeadamente, em curto prazo, na área das finanças públicas ${ }^{173}$.

Uma vez, contudo, que Portugal retome o caminho do crescimento - sendo este o resultado esperado das políticas de austeridade implantadas no país no início da década de 2010 -, espera-se também que o Estado português retome seu papel central como um Estado socioambiental ${ }^{174}$ incentivador de políticas públicas sustentáveis com vistas à efetiva garantia da sustentabilidade econômica, ambiental e social - e, em última instância, da própria dignidade humana.

\section{REFERÊNCIAS BIBLIOGRÁFICAS}

ALENCASTRO, Maria Alice Cruz; SILVA, Edson Vicente da; LOPES, Ana Maria D’Ávila. Contratações sustentáveis na administração pública brasileira: a expe-

mas sim à facticidade decorrente da análise dos contratos públicos. Não é objetivo do texto, portanto, fazer considerações acerca de qual política pública é a correta, posto que isto é subjetivo, mas apenas comprovar que a preocupação econômica - entendida como a redução dos gastos públicos - se sobrepôs à preocupação socioambiental.

173 RODRIGUES, Carlos Sérgio Madureira. Entre a contratação pública ecológica e a contratação pública sustentável: compreender o presente, transpor o futuro. 2014. 153 f. Dissertação (Mestrado) - Faculdade de Direito, Universidade de Coimbra, Coimbra, 2014. Disponível em: <http://hdl.handle.net/10316/28443>. Acesso em: 18 jul. 2015. p. 9.

174 "Superando as limitações tanto do Estado Liberal quanto do Estado Social, o assim chamado Estado Socioambiental conjuga as conquistas (em termos de tutela da dignidade humana e dos direitos humanos e fundamentais) dos modelos de Estado de Direito que o antecederam e passa a incorporar a tutela dos novos direitos ecológicos, numa perspectiva holística e inclusiva, pautada pela sinergia entre os direitos das diversas dimensões. Além disso, cuida-se de um modelo de Estado ancorado no paradigma da solidariedade (nas dimensões nacional, supranacional, intergeneracional [sic] e mesmo interespécies), buscando projetar a comunidade humana num patamar mais evoluído de efetivação de direitos fundamentais e da garantia de uma vida saudável para todos os integrantes da comunidade humana e não-humana". SARLET, Ingo Wolfgang; FENSTERSEIFER, Tiago. O papel do poder Judiciário brasileiro na tutela e efetivação dos direitos (e deveres) socioambientais. In: SILVA, Vasco Pereira da; SARLET, Ingo Wolfgang (Org.). Direito público sem fronteiras. Lisboa: ICJP, 2011. p. 11-63. Disponível em: < http://www.icjp.pt/sites/default/files/media/ebook_dp_completo2_isbn.pdf > . Acesso em: 27 jul. 2015. p. 13, nota 6 . riência do Poder Executivo federal. Revista de Administração Pública, Rio de Janeiro, v. 48, n. 1, jan./fev. 2014. Disponível em: <http://dx.doi.org/10.1590/S0034$76122014000100009>$. Acesso em: 18 jul. 2015.

AMBEC, Stefan; LANOIE, Paul. Does it pay to be green? a systematic overview. Academy of Management. Perspectives, v. 22, n. 4, nov. 2008. Disponível em: <http://fdir.idei.fr/wp-content/uploads/2011/02/ Does-it-Pay-to-be-Green.-A-Systematic-Overview. pdf>. Acesso em: 29 jul. 2015.

ANNUNZIATO, Eduardo Sprada. O impacto da sustentabilidade na formação dos contratos administrativos. Ámbito Jurídico, Rio Grande, v. 14, n. 95, dez. 2011. Disponível em: <http://www.ambitojuridico.com.br/ site/index.php?n_link=revista_artigos_leitura\&artigo_ id=10938 > . Acesso em: 29 jul. 2015.

APPOLLONI, Andrea; D’AMATO, Alessio; CHENG, Wenjuan. Is public procurement going green? experiences and open issues. 2011. Available in: <http://ssrn.com/abstract $=1970583>$. Access: 21 jul. 2015.

ANDRADE, Ana Rita Gomes de. As energias renováveis: uma luz verde aos auxílios do Estado? 2009. $17 \mathrm{f}$. Monografia (Graduação) - Pós-Graduação em Direito da Energia, Instituto de Ciências Jurídico-Políticas da Faculdade de Direito, Universidade de Lisboa, Lisboa, 2009. Disponível em <http://www.icjp.pt/sites/ default/files/media/643-961.pdf $>$. Acesso em: 21 jul. 2015.

BACH, Stephen; STROLENY, Alexandra. Social dialogue and the public services in the aftermath of the economic crisis: strengthening partnership in an era of austerity. Londres: King's College, 2013. Available at: <http://www. kcl.ac.uk/sspp/departments/management/comparative-report.doc $>$. Accessed: 28 jan. 2015.

BASTOS, Filipe Brito. A escolha de critérios ambientais de adjudicação de contratos públicos: reflexões de Direito Administrativo nacional e europeu. Lisboa: ICJP, 2012. Disponível em: <http://www.icjp.pt/sites/default/files/ papers/escolhacriteriosambientaisadjudicacaocp.pdf $>$. Acesso em: 21 jul. 2015.

CAMPOS, Manuel Fontaine. A crise e a regulação internacional e europeia: o "Pacto Orçamental" como solução para a crónica indisciplina financeira do Portugal democrático? In: GONÇALVES, Pedro; GOMES, Carla Amado; MELO, Helena; CALVÃO, Filipa (Coord.). A crise e o direito público. Lisboa: ICJP, 2013. 
p. 81-94. Disponível em: < http://www.icjp.pt/publicacoes/1/4290>. Acesso em: 21 jul. 2015.

COMISSÃO EUROPEIA. Environment. GPP National Action Plans. National GPP Action Plans (policies and guidelines). Available at: <http://ec.europa.eu/environment/gpp/action_plan_en.htm>. Accessed: 22 jul. 2015.

COMISSÃO EUROPEIA. Europa 2020: Estratégia para um crescimento inteligente, sustentável e inclusivo, 2010. Disponível em: <http://eur-lex.europa.eu/ LexUriServ/LexUriServ.do?uri=COM:2010:2020:FIN: PT:PDF>. Acesso em: 20 jul. 2015.

COMISSÃO EUROPEIA. Europe 2020: Europe 2020 in your country. Portugal. Country specific recommendations. Available at: <http://ec.europa.eu/europe2020/ europe-2020-in-your-country/portugal/country-specific-recommendations/index_en.htm>. Accessed: 20 de jul. 2015.

COMISSÃO EUROPEIA. Public procurement reform: environmental aspects. Available at: <http://ec.europa. eu/internal_market/publicprocurement/modernising rules/reform_proposals/index_en.htm>. Accessed: 20 jul. 2015.

COMISSÃO EUROPEIA. Public procurement reform: social aspects of the new rules. Available at: <http:// ec.europa.eu/internal_market/publicprocurement/ modernising_rules/reform_proposals/index_ en.htm>. Accessed: 20 jul. 2015.

COMISSÃO EUROPEIA. Recomendação do Conselho relativa ao Programa Nacional de Reformas para 2015 de Portugal e que formula um Parecer do Conselho sobre o Programa de Estabilidade para 2015 de Portugal, 2015. Disponível em: <http://ec.europa.eu/europe2020/pdf/csr2015/ csr2015_portugal_pt.pdf>. Acesso em: 20 jul. 2015.

DRAGOS, Dacian C.; NEAMTU, Bogdana. Sustainable public procurement in the EU: experiences and prospects. In: LICHERE, Francois; CARANTA, Roberto; TREUMER, Steen (Eds.). Novelties in the 2014 Directive on public procurement. DJØF Publishing, 2014. Available at: <http://ssrn.com/abstract $=2488047>$. Accessed: 22 jul. 2015.

DRAGOS, Dacian C.; NEAMTU, Bogdana. Sustainable public procurement: life cycle costing (LCC) in the new EU Directive proposal. European Public Procurement and PPP Law Review, 2013. Available at: <http://ssrn. com/abstract $=2488021>$. Accessed: 22 jul. 2015.

EIRÓ, Vera. Contratos públicos e insolvência. Uma primeira aproximação. In: GONÇALVES, Pedro; GOMES, Carla Amado; MELO, Helena; CALVÃO, Filipa (Coord.). A crise e o direito público. Lisboa: ICJP, 2013. Disponível em: <http://www.icjp.pt/publicacoes/1/4290>. Acesso em: 21 jul. 2015.

ERIKSSON, Emelie. Green public procurement as a policy instrument. Study from a law and economics perspective on the efficiency of using green public procurement to achieve sustainable development in the EU. 2014. 77 f. Dissertação (Mestrado) - Lund University, Suécia, 2014. Available at: <http://lup.lub.lu.se/luur/downlo ad? func $=$ downloadFile \&recordOId $=4451209 \&$ fileO Id=4465017>. Accessed: 20 jul. 2015.

ESTORNINHO, Maria João. Curso de direito dos contratos públicos: por uma contratação pública sustentável. Coimbra: Almedina, 2014.

FRAGA, Fernando Losada. The Green Paper on the modernization of public procurement policy of the EU: towards a socially-concerned market or towards a market-oriented society? Oñati Socio-Legal Series, v. 2, n. 4, 2012. Available at: <http://ssrn.com/abstract $=2009257>$. Accessed: 22 jul. 2015.

GEELS, Frank W. The impact of the financial-economic crisis on sustainability transitions: financial investment, governance and public discourse. Working paper n. 39. Welfare, wealth and work for Europe. 2013. Available at: <http://www.foreurope.eu/fileadmin/documents/ pdf/Workingpapers/WWWforEurope_WPS_no039_ MS205.pdf>. Accessed: 22 jul. 2015.

GONÇALVES, Pedro Costa. Concorrência e contratação pública: a integração de preocupações concorrenciais na contratação pública. In: ESTUDOS em homenagem a Miguel Galvão Teles. Coimbra: Almedina, 2012. v.1.

GONÇALVES, Pedro Costa. Alterações ao código dos contratos públicos na sequência do "Memorando de Entendimento com a Troika". Revista de contratos públicos, Coimbra, n. 5, maio/ago. 2012.

LUNDBERG, Sofia; MARKLUND, Per-Olov; BRÄNNLUND, Runar. Assessment of green public procurement as a policy tool: cost-efficiency and competition considerations, 2009. Available at: <http://ssrn.com/ abstract=1831089>. Accessed: 22 jul. 2015. 
MARTINS, Ana Maria Guerra. Manual de direito da União Europeia. Coimbra: Almedina, 2014.

MATEI, Ani I.; MATEI, Lucica. Modernisation of the public procurement market. Towards a strategy of public marketing specific on the single market. Societal Innovations for Global Growth; Stream C: National Sustainable Development under Globalization Conditions, 2012. v. 1. Available at: $<$ http://ssrn.com/abstract $=2135420>$. Accessed: 22 jul. 2015.

MEDEIROS, Rui. A constituição portuguesa num contexto global. Lisboa: Universidade Católica, 2015.

MIRA, Maria Emília. Gestão ambiental na administração publica central portuguesa. O caso da contratação pública: aquisições ecológicas e gestão de resíduos. 2011. 128 f. Dissertação (Mestrado) - Universidade Aberta, Lisboa, 2011. Disponível em: <http://hdl.handle. net/10400.2/1899>. Acesso em: 18 jul. 2015.

NABAIS, José Casalta. Da sustentabilidade do Estado fiscal. In: NABAIS, José Casalta; SILVA, Suzana Tavares da (Coord.). Sustentabilidade fiscal em tempos de crise. Coimbra: Almedina, 2011.

PARDAL, Paulo Alves. A contratação pública sob os ventos da austeridade orçamental. In: FERREIRA, Eduardo Paz; RODRIGUES, Nuno Cunha (Coord.). Novas fronteiras da contratação pública. Coimbra: Coimbra, 2013.

PEREIRA, Pedro Matias; FRANCO, João Soares. A adjudicação de contratos públicos em contexto de crise. Revista de contratos públicos, Coimbra, n. 5, maio/ago. 2012.

PINHEIRO, André Modesto. Parcerias público-privadas, o papel do Estado: da densificação do conceito de comparador do sector público à problemática do reequilíbrio financeiro. 2011. 50 f. Dissertação (Mestrado) - Universidade Católica Portuguesa. Lisboa, 2012. Disponível em: < http://hdl.handle.net/10400.14/10285>. Acesso em: 18 jul. 2015.

PORTUGAL. Tribunal de Contas. Acórdão n. 40/2010. Processo n. 1303/201003. $1^{\text {a }}$ S/SS. 03 de novembro 2010. Disponível em: < http://www.tcontas.pt/pt/actos/acordaos/2010/1sss/ac040-2010-1sss.pdf > . Acesso em: 29 jul. 2015.

PORTUGAL. Assembleia da República. Constituição da República Portuguesa. VII Revisão Constitucional (2005). Disponível em: <http://www.parlamento.pt/Legisla-
cao/Documents/constpt2005.pdf>. Acesso em: 25 jun. 2015.

PORTUGAL. Portal BASE. Contratação pública em Portugal: relatório síntese 2010, 2011. Disponível em: <http://www.base.gov.pt/mediaRep/inci/files/base_ docs/Rel_Contr_Publ_2010.pdf>. Acesso em: 23 jul. 2015.

PORTUGAL. Portal BASE. Contratação pública em Portugal 2013, 2015. Disponível em: < http://www.base.gov. pt/mediaRep/inci/files/base_docs/RelContratosPublicos_2013.pdf>. Acesso em: 23 jul. 2015.

PORTUGAL. Procuradoria-Geral Distrital de Lisboa. Código dos Contratos Públicos. Decreto-Lei $n$. 18, de 29 de janeiro de 2008. Atualizada pelo Decreto-Lei n. 149, de 12 de julho 2012. Disponível em: $<$ http://www.pgdlisboa.pt/leis/lei_mostra_articulado. php?nid $=2063 \&$ tabela $=$ leis\&so_miolo=> . Acesso em: 20 jul. 2015.

PORTUGAL. Ministério das Finanças. Unidade Técnica de Acompanhamento de Projetos. Decreto-Lei n. 111/2012 de 23 de maio. Diário da República, $1^{\text {a }}$ série, n. 100, 2012, p. 2702-2713. Disponível em: <http://www. utap.pt/Publicacoes_utap/0270202713.pdf $>$. Acesso em: 25 jan. 2015.

PORTUGAL. Ministério da Economia e do Emprego. Decreto-Lei n. 149/2012 de 12 de julho. Diário da República, $1^{\text {a }}$ série, n. 134, 2012, p. 3639-3645. Disponível em: <http://www.contratacaopublica.com.pt/xms/files/ Legislacao/Portuguesa/DL_149_2012.pdf>. Acesso em: 21 jul. 2015.

PORTUGAL. Portal BASE. Estatisticas: gráfico geográfico. Disponível em: <http://www.base.gov.pt/Base/ pt/Estatisticas/GraficoGeografico $>$. Acesso em: 25 jul. 2015.

PORTUGAL. Memorando de entendimento sobre as condicionalidades de política económica, 2011. Disponível em: <http://www.contratacaopublica.com.pt/xms/files/ Documentacao/MoU_PT17maio2011.pdf>. Acesso em: 21 jul. 2015.

PORTUGAL. Portal BASE. O portal BASE. Disponível em: <http://www.base.gov.pt/Base/pt/OPortal/ Base>. Acesso em: 23 jul. 2015.

PORTUGAL. Autoridade da Concorrência. O programa de clemência. O que são cartéis. Disponível em: <http://www.concorrencia.pt/vPT/Praticas_ 
Proibidas/O_programa_de_clemencia/Tipos_de_carteis/Paginas/O-que-sao-carteis.aspx>. Acesso em: 29 jul. de 2015.

PÚBLICO. Memorando da Troike anotado, 2014. Disponível em: <http://www.publico.pt/economia/memorando-da-troika-anotado >. Acesso em: 21 jul. 2015.

QUADROS, Fausto de. Direito da União Europeia: direito constitucional e direito administrativo da União Europeia. 3. ed. Coimbra: Almedina, 2013.

RAIMUNDO, Miguel Assis. A formação dos contratos públicos: uma concorrência ajustada ao interesse público. Lisboa: AAFDL, 2013.

RIBEIRO, Gonçalo de Almeida; COUTINHO, Luís Pereira (Org.). O Tribunal Constitucional e a crise: ensaios críticos. Coimbra: Almedina, 2014.

RODRIGUES, Carlos Sérgio Madureira. Entre a contratação pública ecológica e a contratação pública sustentável: compreender o presente, transpor o futuro. 2014. 153 f. Dissertação (Mestrado) - Faculdade de Direito, Universidade de Coimbra, Coimbra, 2014. Disponível em: <http://hdl.handle.net/10316/28443>. Acesso em: 18 jul. 2015.

RODRIGUES, Nuno Cunha. A contratação pública como instrumento de politica económica. Coimbra: Almedina, 2015.

ROQUE, Miguel Prata. A dimensão transnacional do direito administrativo: uma visão cosmopolita das situações jurídico-administrativas. Lisboa: AAFDL, 2014.

SARLET, Ingo Wolfgang; FENSTERSEIFER, Tiago. O papel do poder Judiciário brasileiro na tutela e efetivação dos direitos (e deveres) socioambientais. In: SILVA, Vasco Pereira da; SARLET, Ingo Wolfgang (Org.). Direito público sem fronteiras. Lisboa: ICJP, 2011. p. 11-63. Disponível em: <http://www.icjp.pt/sites/default/files/media/ebook_dp_completo2_isbn.pdf $>$. Acesso em: 27 jul. 2015.

SILVA, Suzana Tavares da. Sustentabilidade e solidariedade em tempos de crise. In: NABAIS, José Casalta; SILVA, Suzana Tavares da (Coord.). Sustentabilidade fiscal em tempos de crise. Coimbra: Almedina, 2011.

TAYLOR, Charles. Argumentos filosóficos. São Paulo: Loyola, 2000.

TRABUCO, Cláudia. Existem empresas que não são empresas? as entidades adjudicantes e o conceito jus-concorrencial de empresa. In: TRABUCO, Cláudia;
EIRÓ, Vera. Contratação pública e concorrência. Coimbra: Almedina, 2013.

UNIÃO EUROPEIA. Directiva 2004/17/CE do Parlamento Europeu e do Conselho, de 31 de Março de 2004. Relativa à coordenação dos processos de adjudicação de contratos nos sectores da água, da energia, dos transportes e dos serviços postais. Jornal Oficial, n. L 134, de 30 de abril de 2004, p. 1-113. Disponível em: <http://eur-lex.europa.eu/legal-content/PT/ TXT/?uri=CELEX:32004L0017>. Acesso em: 20 jul. 2015.

UNIÃO EUROPEIA. Directiva 2004/18/CE do Parlamento Europeu e do Conselho, de 31 de Março de 2004. Relativa à coordenação dos processos de adjudicação dos contratos de empreitada de obras públicas, dos contratos públicos de fornecimento e dos contratos públicos de serviços. Jornal Oficial, n. L 134, de 30 de abril de 2004, p. 114-240. Disponível em: <http:/ / eur-lex.europa.eu/ legal-content/PT/TXT/?uri=CELEX:32004L0018>. Acesso em: 20 jul.2015.

UNIÃO EUROPEIA. Direito da UE. Regulamentos, directivas e outros actos legislativos. 2015. Disponível em: $<$ http:/ / europa.eu/eu-law/decision-making/legal-acts/index_pt.htm>. Acesso em: 20 jul. 2015.

UNIÃO EUROPEIA. Diretiva 2014/23/UE do Parlamento Europeu e do Conselho, de 26 de fevereiro de 2014. Relativa à adjudicação de contratos de concessão. Jornal Oficial da União Europeia, n. L 94/1, de 28 de março de 2014. Disponível em: <http:/ / eur-lex.europa.eu/ legal-content/PT/TXT/?uri=CELEX:32014L0023>. Acesso em: 20 jul. 2015.

UNIÃO EUROPEIA. Diretiva 2014/24/UE do Parlamento Europeu e do Conselho, de 26 de fevereiro de 2014. Relativa aos contratos públicos de obras, fornecimentos ou serviços e que revoga a Diretiva 2004/18/CE. Jornal Oficial da União Europeia, n. L 94/ 65, de 28 de março de 2014. Disponível em: <http:/ / eur-lex.europa.eu/ legal-content/PT/TXT/?uri=CELEX:32014L0024>. Acesso em: 20 jul. 2015.

UNIÃO EUROPEIA. Diretiva 2014/25/UE do Parlamento Europeu e do Conselho, de 26 de fevereiro de 2014. Relativa aos contratos públicos celebrados pelas entidades que operam nos setores da água, da energia, dos transportes e dos serviços postais e que revoga a Diretiva 2004/17/CE. Jornal Oficial da União Europeia, n. L 94/243, de 28 de março de 2014. Disponí- 
vel em: <http://eur-lex.europa.eu/legal-content/PT/ TXT/?uri=CELEX:32014L0025>. Acesso em: 20 jul. 2015.

UNIÃO EUROPEIA. Regulamento (CE) n. 213/2008 da Comissão de 28 de novembro de 2007 que altera o Regulamento (CE) n. 2195/2002 do Parlamento Europeu e do Conselho. Relativo ao Vocabulário Comum para os Contratos Públicos (CPV), e as Directivas do Parlamento Europeu e do Conselho 2004/17/CE e 2004/18/CE, relativas aos processos de adjudicação de contratos, no que respeita à revisão do CPV. Jornal Oficial da União Europeia, n. L 74/1, de 15 março de 2008. Disponível em: <http://eur-lex.europa.eu/LexUriServ/LexUriServ.do?uri=OJ:L:2008:074:0001:0375:PT: PDF>. Acesso em: 24 jul. 2015.

UNIÃO EUROPEIA. Versões consolidadas do Tratado da União Europeia e do Tratado sobre o Funcionamento da União Europeia. Tratado da União Europeia (Versão consolidada). Tratado sobre o Funcionamento da União Europeia (Versão consolidada). Protocolos. Anexos. Declarações anexadas à Ata Final da Conferência Intergovernamental que adotou o Tratado de Lisboa assinado em 13 de dezembro de 2007 - Quadros de correspondência. Jornal Oficial, n. C 326, de 26 outubro 2012, p. 1-390. Disponível em: <http://eur-lex.europa. eu/legal-content/PT/TXT/?uri=CELEX:12012E/ TXT>. Acesso em: 24 jul. 2015.

\section{(Footnotes)}

1 Além desses tipos de contrato, no site do Portal BASE encontram-se, também, os seguintes: "concessão de obras públicas"; "concessão de serviços públicos"; "locação de bens móveis"; "sociedade" e "outros". Optou-se apenas por mostrar os contratos de bens e serviços e de empreitadas de obras públicas por terem sido estes a base dos relatórios apresentados anteriormente neste texto. 2 A quantidade a seguir apresentada corresponde ao número total de contratos que aparecem logo após a realização da pesquisa e não ao número de contratos que tenham algum fator socioambiental como critério de adjudicação. Tal distinção será feita a seguir neste texto.

3 O número total de contratos deste CPV e deste tipo é de 34. Contudo, um deles, de 2010, não tinha seu anúncio disponível no Portal BASE, sendo por tal motivo excluído da contagem final.

4 O número total de contratos deste CPV e deste tipo é de 14. Contudo, quatro deles, de 2010, não tinham seus respectivos anúncios disponíveis no Portal BASE, sendo por tal motivo excluídos da contagem final.

5 O número total de contratos deste CPV e deste tipo é de 29. Contudo, quatro deles, de 2010, não tinham seus respectivos anúncios disponíveis no Portal BASE, sendo por tal motivo excluídos da contagem final.

6 O número total de contratos deste CPV e deste tipo é de 12. Contudo, um deles, de 2010, não tinha seu anúncio disponível no Portal BASE, sendo por tal motivo excluído da contagem final.

7 O número total de contratos deste CPV e deste tipo é de 42. Contudo, um deles é de 2009, ou seja, está fora do período analisado, sendo por tal motivo excluído da contagem final. Além deste, outros dois contratos, um de 2010 e outro de 2012, não tinham seu anúncio disponíveis no Portal BASE, sendo por tal motivo excluídos da contagem final. 
Para publicar na Revista de Direito Internacional, acesse o endereço eletrônico www.rdi.uniceub.br ou www.brazilianjournal.org.

Observe as normas de publicação, para facilitar e agilizar o trabalho de edição. 